\title{
A SOCIOLOGICAL STUDY OF THE RELATIONS OF MAN TO THE LAND IN NICARAGUA
}

By

EDGAR G. NESMAN

\begin{abstract}
A DisSERTATION PRESENTED TO THE GRADUATE COUNCIL OF THE UNIVERSITY OF FLORIDA IN PARTIAL FULFILLMENT OF THE REQUIREMENTS FOR THE DEGREE OF DOCTOR OF PHILOSOPHY
\end{abstract}

UNIVERSITY OF FLORIDA

1969 


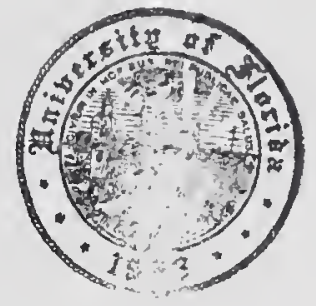

UNIVERSITY OF FLORIDA

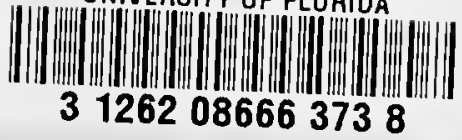


ACKNOWLEDGMENTS

This dissertation represents the results of many years of reading, listening, observing and thinking as weII as a full year of concentrated effort in research and writing.

I would like to acknowledge the early help given by my father, Glen W. Nesman, who served for more than a quarter of a century as a teacher and friend of rural people in Michigan. In more recent times I have received much counsel from professional colleagues throughout Latin America, many of whom are working for the promotion of agrarian reform. I am also indebted to thousands of farmers in various parts of Latin America and especially to hundreds of those in Nicaragua, who have shared with me their problems and preoccupations, as well as their joys and aspirations. Both the wealthy and the poor have been kind enough to tell me of the intricate web of relationships that they have with the land that they love and on which they Iive.

During my period of study at the University of Florida, Professor T. Lynn Smith has been both an inspiring teacher and a constant guide in this study. Without his help this dissertation would not have been possible. 
Many others have been instrumental in aiding me see the importance of particular aspects of this study. I would like especially to mention the following: Dr. Joseph S. Vandiver and Dr. Wilbur Bock of the department of sociology; Dr. Raymond Crist of the department of geography; and Dr. E. Shaw Grigsby of the Cooperative Agricultural Extension Service. All five of those mentioned have served as members of my supervisory committee.

I also desire to mention those who have helped with the production of the written manuscript, namely, Mr. Parke Renshaw, Mrs. Eileen Brand, and Mrs. Shirley Kester.

Most of all I am indebted to my wife, Marjorie, who has been typist, reader, sounding board, and helper in a thousand ways during the years that this work has been underway. 
TABLE OF CONTENTS

Page

ACKNOWLEDGMENTS. • . . . . . . . . . • • •

LIST OF TABLES............. . . vii

LIST OF FIGURES .............. . . . ix

ABSTRACT ................ . ${ }^{x} \mathrm{x}$

CHAPTER

I. INTRODUCTION . . . . . . . . . .

Scope of the Study ..........

Sources of the Data and Methods....

Importance of the Study . . . . . .

Order of Presentation........

II. REVIEW OF THE LITER TURE . . . . . . . 8

General Works.......... 8

Works in Man-Land Relations in Latin

America .......... 17

The Study of the Relations of Man and

Land in Nicaragua . . . . . . 25

III. SIZE OF FARMS . . . . . . . . . 29

Classification of Farms ....... 34

Size of Farms in Nicaragua . . . . . 37

Regional Comparisons ........ 44

Size of Explotaciones and Land Use . . 48

Factors Responsible for Present Pattern

of Landholding . . . . . . . . 53

Results of the Concentration of Land 58

Ownership and Control ...... . 58

Trends in Landholding...... . : 66 
Page

CHAPTER

IV. LAND TENURE . . . . . . . . . . . 7 I

Property Rights and Their Development . . 73

The Tenure Status of Nicaragua Farm

Personnel . . . . . . . . . . 80

Regional Variations in Tenure Status . . 94

Variations in Tenure Status in Nicaragua

According to Size of Farm and Land

Use ............. . 101

Other Aspects of Land Tenure in

Nicaragua ........... 104

Summary and Conclusions ....... 106

V. LAND DIVISION, LAND SURVEYS, AND LAND

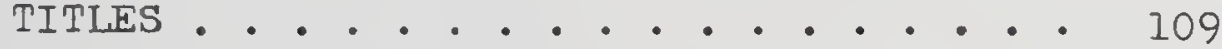

Types of Land Surveys . . . . . . . . . 111

Contemporary Land Division, Land Surveys,

and Land Titles in Nicaragua.....

Causes of the Contemporary Situation . . 126

Results of the Contemporary Situation. . 128

Development and Trends . . . . . . 129

Summary and Conclusions . . . . . . 132

VI. SETtLENENT PATTERNS . . . . . . . . 134

Principal Types of Settlement..... . 135

Contemporary Settlement Patterns in

Nicaragua ......... . 140

Variations in Settlement Patterns... . 145

Factors Responsible for Present-Day

Settlement Patterns . . . . . . 148

Results of Present-Day Settlement

Patterns........... 149

Evolution and Trends . . . . . . . 150

Summary and Conclusions....... 153

VII. SYSTEMS OF AGRICULTURE . . . . . . . 155

Contemporary Systems of Agriculture in

Nicaragua ........... 158

Reasons for Present Systems . . . . . 175

The Effect of Contemporary Systems of

Agriculture . . . . . . . . 178 
TABLE OF CONTENTS

Page

CHAPTER

VII. SYSTEMS OF AGRICULTURE (Continued)

The Evolution of Agricultural Systems

in Nicaragua . . . . . . . . . 179

Summary and Conclusions... . . . . 192

VIII. SUMMARY AND CONCLUSIONS . . . . . . 195

GLOSSARY . . . . . . . . . . . . . 204

BIBLIOGRAPHY . . . . . . . . . . . 209

APPENDIX . . . . . . . . . . . . . . . 220

BIOGRAPHICAL SKETCH . . . . . . . . . 232 


\section{LIST OF TABLES}

Table

Page

1. Size of the Explotaciones Agropecuarios in Nicaragua, 1963 . . . . . . . 39

2. Relative Importance of Various Sizes of

Explotaciones Agropecuarios by

Geographical Regions in Nicaragua,

1963 . . . . . . . . . 45

3. Proportion of Crop Land, Pasture Land

and Forest Land by Geographical Regions

in Nicaragua, 1963 . . . . . . . .

4. Relative Importance of Cropland, Pastureland, and Forestland in Nicaragua by

Size of Explotaciones Agropecuario, 1963 . . . . . . . . . . .

5. Size of Explotaciones Agropecuarios in Nicaragua, 1952 . . . . . . . 65

6. Comparative Size of Explotaciones Agropecuarios in Nicaragua, 1952 and 1963 ........... . . 67

7. Explotaciones Agropecuarios According to Size in Nicaragua, $1963 . . . .984$

8. Population Economically Active in Agriculture and Stock Raising According to Occupational Level in Nicaragua, 1963

9. Number of Explotaciones Agropecuarios According to Size and Tenure Status in Nicaragua, 1963 . . . . . . . 90

10. Number of Explotaciones Agropecuarios According to Tenure Status by Geographical Regions in Nicaragua, 1963. . 


\section{LIST OF TABLES}

Table

Page

11. Amount of Agricultural Land in Different Tenure Classifications by Geographical Regions in Nicaragua, 1963 . . . . . 96

12. Number and Area of Explotaciones Agropecuarios Under Rental Arrangements by Geographical Region in Nicaragua, 1963 . . . . . . . . 9 98

13. Number of Economically Active Persons in the Rural Population According to Occupational Level and Geographical Region in Nicaragua, 1963 . . . . . . 99

14. Amount of Agricultural Land in Different T'enure Categories According to Size of Explotaciones Agropecuarios in Nicaragua, 1963 . . . . . . . . 102

15. Selected Aspects of Technification of Agriculture in Nicaragua, 1967 . . . . 173

16. Number of Oyen, Mules, Asses and Horses in Nicaragua, 1952 and $1963 . . . .190$ 


\section{LIST OF FIGURES}

Figure

Page

1. Republic of Nicaragua, Departamentos and National Boundaries . . . . . . . I

2. Index of Available Topographical Maps of Nicaragua . . . . . . . . . 117

3. Index of Available Planimeter Maps of Ni caragua . . . . . . . . . 118

4. Survey of Proposed Agricultural Colony "El Guanacaston." •. . . . . . 120

5. Settlement Patterns in the Pacific Region of Nicaragua, 1961 . . . . 142

6. Settlement Patterns in North-Central Region of Nicaragua, 1961 . . . . . 144

7. Settlement Patterns in the At lantic Region, Nicaragua, 1961 . . . . . 147

8. Agricultural equipment used in Nicaragua . 166 
Abstract of Dissertation Presented to the Graduate Council in Partial Fulfillment of the Requirements for the Degree of Doctor of Philosophy

\title{
A SOCIOLOGICAL STUDY OF THE RELATIONS OF MAN TO THE LAND \\ IN NICARAGUA
}

\author{
By \\ Edgar G. Nesman \\ March, 1969
}

Chairman: Dr. T. Lynn Smith

Major Department: Sociology

This dissertation is an analysis of the institutionalized relations of man to the land in Nicaragua. Five aspects of the subject are dealt with in the study: the size of farms; land tenure; land division, surveys, and titles; settlement patterns; and systems of agriculture.

An investigation of this nature is important for Nicaragua where a large proportion of the population is directly dependent upon agriculture. No other sociological study of this kind has been attempted in Nicaragua. The frame of reference developed by Professor T. Lynn Smith served as the principal guideline for this study 
Most of the data used came from direct observation and personal interviews with hundreds of Nicaraguans in 30 rural communities. These materials were gathered in the course of seven visits to Nicaragua in the years 1961 to 1968. The 1963 censuses of population, agriculture, and housing also furnished large amounts of highly pertinent data. Of course, much time had to be expended in assembling pertinent materials and making thousands of computations in order to bring the census data to bear directly upon the ideas involved in this dissertation. After the tentative findings had been set forth in a systematic manner, the seventh trip to Nicaragua was for the purpose of checking and verifying the provisional conclusions.

The findings of the study are summarized under four major headings: the present situation, the causes, the effects, and the development and trends. Presently there are approximately 1,500,000 inhabitants in Nicaragua; and about 140,000 , or 60 per cent, of the families, are economically dependent on agriculture and stock raising. One half of these families are headed by farm operators and an equal proportion by farm laborers. A mere 4.0 per cent of the farm operators control 59.8 per cent of the land in farms. The majority of the farms are dependent on methods of cultivation that were in use 5,000 years ago. In contrast, on a few large farms 
the latest machines and techniques are employed in the production of crops for export.

of all the factors responsible for the present relations of man and land in Nicaragua, the cultural heritage, which guarantees the privileged position of the landed aristocracy, is probably the most important. Other things that have helped perpetuate these relations are: an abundance of agricultural land, a geographical position which has fostered foreign intervention, incessant factional strife and frequent civil wars, and a highly centralized control of military, political, economic, and governmental power.

Some of the effects of the present institutionalized relationships of man to the land in Nicaragua are: low crop yields, inefficient use of natural and human resources, small incomes, and generally low levels of living. All of these are characteristic of the majority of the families dependent on agriculture and stock raising for a livelihood. In tracing the developments and trends, it is found that an agricultural society was in existence in Nicaragua before the coming of the Spaniards. The conquerors divided the possession of the land among themselves according to their rank, and each used the products of the land to maintain his social position. The close association of power and prestige with ownership and control of the land has persisted to this day. Since 
1950 there have been many demands for a more equitable distribution of the ownership and control of the land and its products among the farm personnel. Some changes have been made as a result of the Agrarian Reform Law, passed in 1963. However, much still remains to be done before the needs and the demands of the largest sector of the rural population can be met. 


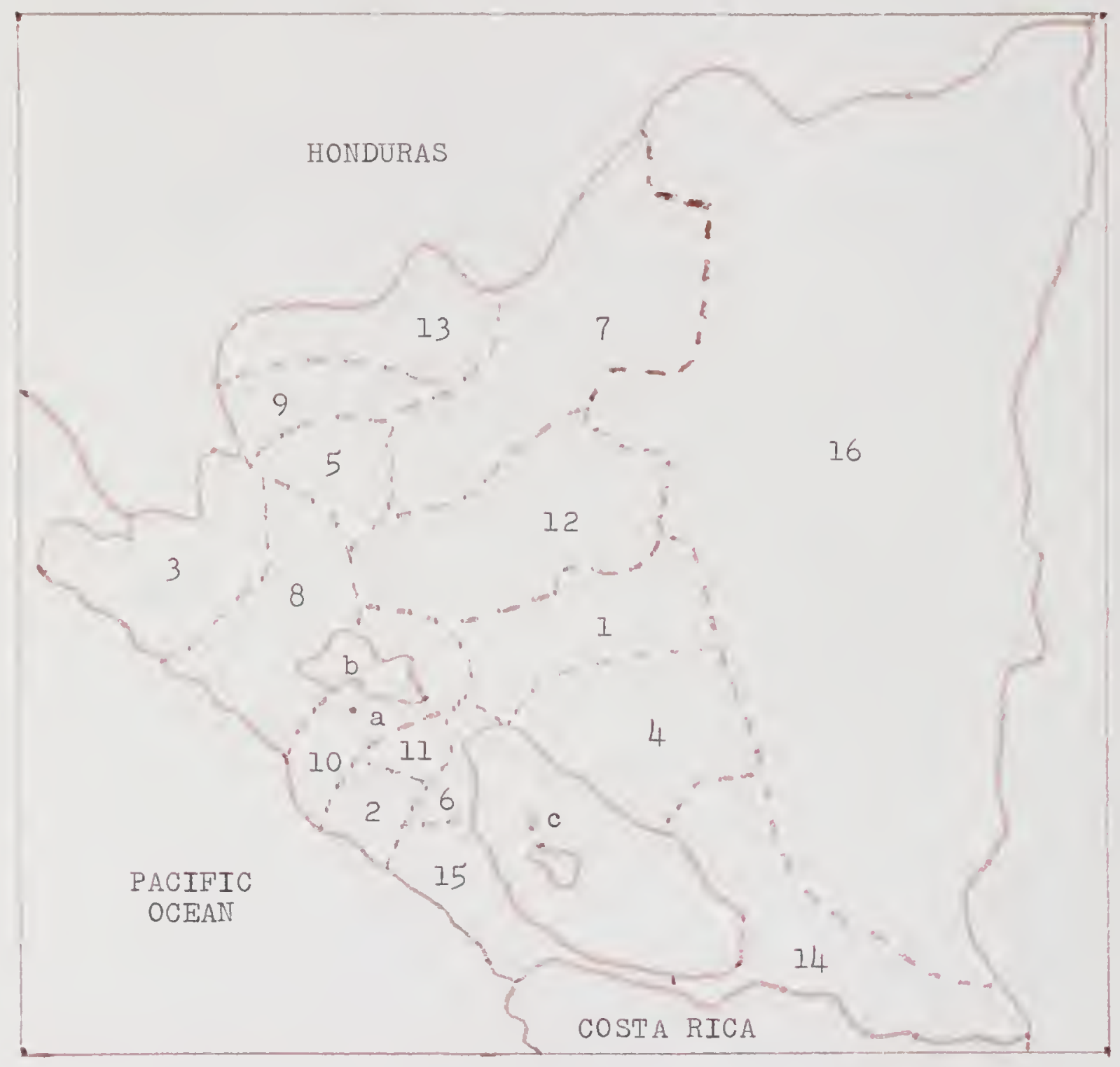

Figure 1. Republic of Nicaragua, Departamentos and National Boundaries.* Source: Republic of Nicaragua, Census of 1963.

* Departamentos

$\begin{array}{ll}\text { 1. Boaco } & \text { 9. Madriz } \\ \text { 2. Carazo } & \text { 10. Managua } \\ \text { 3. Chinandega } & \text { 11. Masaya } \\ \text { 4. Chontales } & \text { 12. Matagalpa } \\ \text { 5. Esteli } & \text { 13. Nueva Segovia } \\ \text { 6. Granada } & \text { 14. Rio San Juan } \\ \text { 7. Jinotega } & \text { 15. Rivas } \\ \text { 8. Leon } & \text { 16. Zelaya }\end{array}$

a. Managua

b. Lake

Managua

c. Lake

Nicaragua 
CHAPTER I

INTRODUCTION

This study is a sociological analysis of the relationships between man and the land in Nicaragua. The specific objectives of this investigation are: (1) to determine and portray the present relationships of man to the land; (2) to trace the development of these relationships from the pre-Columbian era up to the present time; (3) to identify and to measure to some extent the factors that are responsible for the present relationship; and (4) to examine briefly how these relationships have affected other aspects of Nicaragua's society.

Up to this time, there have been no broad and general empirical sociological studies of rural social organization in Nicaragua. The present work is an attempt to help fill this gap. It is hoped that this analysis and description of certain features of rural society in Nicaragua will lay a foundation for future meaningful investigations.

A number of questions were posed initially to serve as guides as the work proceeded. They are as follows: What are the geographical, historical and demographic backgrounds of present man-land relations 
in Nicaragua? To what degree are the ownership and control of the land concentrated in the hands of a few people? What legal property rights to the land does a private individual enjoy and how are these rights distributed among those who depend on farming for their livelihood? How is the land surveyed and divided, and what system or lack of it is used in recording the titles to the separate tracts? What settlement patterns prevail, i.e., how are the dwellings arranged with respect to the land and to one another? And finally, what are the ways and means or the systems used in extracting products from the soil?

\section{Scope of the Study}

The entire Republic of Nicaragua is the area included in this study, but our particular concern is with the rural people and the rural areas of the country. Moreover, our primary concern is with the present situation, or that prevailing during the 1960's, although the changes under way are considered as much as feasible.

The specific man-land relationships upon which attention is focused are: (1) the size of the farms; (2) land tenure; (3) land surveys, land division and titles; (4) settlement patterns; and (5) systems of agriculture. One chapter is devoted to each of these subjects. 
Sources of the Data and Methods

The pioneer nature of this present study has necessarily had great bearing on the ways in which the data were obtained. The descriptions and analysis herein presented are based largely upon extensive personal observation in all parts of Nicaragua, informal interviews with hundreds of Nicaraguans in all levels of society, and extensive statistical data in the censuses and other official sources.

The personal observations and interviews were made during a period of four years while I was supervising field work in adult education and community development programs. This gave me intimate contact with the inhabitants of 30 rural localities in western Nicaragua. On two occasions I traveled extensively in the other parts of the country as well. Because I lodged in the homes of the people, I was able to talk with them in an unhurried manner. As mutual confidence was established, it was possible for me to learn about their values and aspirations as well as to become acquainted with the intricate web of social relationships that serve as the framework for their lives. More than 1,000 people have supplied some information and the number includes people at every level, from the humblest field laborers to high governmental officials. 
The use of a daily journal served as an aid to observation and also as the means of recording information obtained during the interviews. Each evening, or at the beginning of a new day, the main events of the previous day were recorded. Portions of this record are included in the Appendix under the title, "Rural Life in Nicaragua."

Observations made by the members of the teams working under my supervision were also of value to this study. In each community studied the teams attempted to determine the total number of inhabitants, the occupations of the workers, and the level of living of the various families. They also recorded many general observations on the relationships of man to the land. Most of the data used were originally gathered and recorded by use of the Spanish language. All translations have been made with common usage in mind and are based on my experience of 16 years in working with technicians and rural people in Latin America. Any errors of interpretation are my own, and for them I accept full responsibility. A glossary of Spanish words is included on pages 204-208.

The methods used in the tabulation and analysis of the data are the conventional statistical devices. No new scales or indexes were developed. Tabular cross tabulation and comparisons are used extensively. 
Land has always been of importance to man. In primitive societies the relationship had a mystical quality. It is more than just the relation of soil, food and life; it is the soil of a locality that is important to man. This can be seen today in the highlands of Bolivia where the land of one's birth is considered almost a part of one's personality. The social interaction and expectations that develop from this relationship are deep and enduring. A study of any society would be incomplete without an understanding of this bond.

In addition to the fact that no such study has been made previously, there are several reasons for the crucial nature of this understanding of present relationships of the Nicaraguans to their soil. The growth of the population, the social significance of land ownership, the interrelation of agriculture and the total life of the farmer, the change from subsistence farming to commercial agriculture, the political agitation in favor of agrarian reform, social and behavioral changes among rural people, and the inescapable influence of social factors make imperative new understanding of basic man-land relationships. This study attempts to help fill this gap as well as add to the growing body of knowledge of manland relations in general. 


\section{Order of Presentation}

The findings of this study are presented in three main parts, an Introduction, a major consideration of Man-Land Relationships, and, finally, the Conclusions. The introductory section is composed of two chapters, including the present one which presents the nature and significance of the study. The second chapter is dedicated to a review of the literature on man-land relations in Nicaragua.

In the second part, the body of the dissertation, one chapter is devoted to each of the five basic aspects of man-land relations in Nicaragua. These are as follows: Chapter III, Size of Farms; Chapter IV, Land Tenure; Chapter V, Land Division, Land Surveys and Land Titles; Chapter VI, Settlement Patterns; and Chapter VII, Systems of Agriculture.

The final part, composed of a single chapter, number VIII, is a Summary and Conclusions. This is followed by a glossary of spanish terms. The Appendix contains portions of my daily journal entitled "Rural Life in Nicaragua." 
CHAPTER II

REVIEW OF THE LITERATURE

To be useful as a tool of analysis, a frame of reference must be systematic, must provide categories that can be measured, and must apply to a wide number of situations. In reviewing the literature on the institutional relationship of man to the land, it is important to trace the gradual development and refinement of just such a frame of reference.

This review is divided into three principal parts: general works on man-land relations; titles dealing with man-land relations in Latin America; and studies of manland relations in Nicaragua.

\section{General Works}

The development of the systematic study of the institutional relationships between man and the land follows the development of sociology in general and rural sociology in particular as independent disciplines. In 1894, Albion W. Small and George E. Vincent published An Introduction to the Study of Society in answer to a growing need for a textbook to be used in college courses 
in sociology. I In their description of the gradual development of society, they mention such rural features as settlement patterns, land tenure, and land division, land surveys, and land titles in the two chapters entitled "The Family on the Farm" and "The Rural Group." These items were not treated in detail but were mentioned as important considerations in the analysis of rural society. Thus, even in the earliest publications of sociological literature in the United States, the relationships of man and land were given attention.

As sociology developed, the concern for rural society became one of the foremost areas of interest. In 1913 John M. Gillette published the first textbook on rural sociology, Constructive Rural Sociology. ${ }^{2}$ No section of the book is specifically dedicated to man-land relations but the chapter entitled "Types of Communities" makes brief mention of types of settlement. Another chapter, "Social Isolation and Socialisation" goes into considerable detail as to the social effects of isolated farmsteads. In the chapter, "Improvement of Agricultural Production" a number of aspects related to systems of agriculture

IAlbion $W$. Small and George E. Vincent, An Introduction to the Study of Society (New York: American Book

2John M. Gillette, Constructive Rural Sociology (New York: Sturgis and Walton, 1913). 
are considered. Still another chapter entitled "Social Aspects of Land and Labor in the United States" discusses at length some aspects of size of farms and land tenure. Gillette makes frequent reference to individuals and groups that have had interest in rural problems, both at home and abroad. The Report of the Country Life Commission is mentioned often as well as publications that describe rural Iife in England and Europe.

Bennett's book, Problems of Village Life, published in 1914 is an example of the work that was being done in England. 3 This book is largely descriptive of rural life in general but it does deal specifically with size of holdings and land tenure. For one interested in going back further in history, his book has included an excellent bibliography of prior works on rural society including a number that are more closely related to man-land relations. In 1915, a milestone in the systematic studies of rural life was written by Galpin. His work, The Social Anatomy of an Agricultural Community gave some insight into settlement patterns and land tenure but its major contribution was that of applying the scientific method to the study of rural society. 4

3 Ernest M. Bennett, Problems of Village Life (London: Williams and Norgate, 1914).

${ }^{4}$ Charles J. Galpin, The Social Anatomy of an Agricultural Community (Wisconsin Agricultural Experiment Station Bulletin 34, Madison, 1915). 
In 1917, another text on rural society was written, Vogt's Introduction to Rural Sociology. In it considerable space and detail were dedicated to size of farms and land tenure in the chapter, "The Land Question and Rural Welfare." 5 Available data are used in tabular form to show how these two items are related to levels of living. Settlement patterns are mentioned in a section of the chapter, "Rural Social Organization."

In the 1920's a number of works were added to those previously mentioned, each making a contribution to the development of an adequate frame of reference for the study of man's institutional relationship to the land. Gillette's Rural Sociology suggested a classification for different types of rural commuities as well as categories useful for the study of agricultural labor. 6 Taylor's book, Rural Sociology called for more systematic studies of rural society and made suggestions as to how they should be done. 7 He makes ample use of census data in his chapter "The Problem of Tenancy and Ownership" in which he treats the problem of the concentration of ownership and control of the land in detail. About this same 5Evon A. Vogt, Introduction to Rural Sociology
(New York: D. Appleton and Company,

${ }^{6} \mathrm{John}$ M. Gillette, Rural Sociology (New York: The Macmillan Company, 1922).

${ }^{7}$ Carl C. Taylor, Rural Sociology (New York: Harper and Brothers, 1926). 
time (1927) two books appeared as a result of the studies of Edmund de S. Brunner and his associates in the Institute of Social Religious Research. ${ }^{8}$ These books reported the findings of studies made of 140 rural communities in the United states. In these books as well as that of Taylor, reference is made to the effect of the institutional relationships of man and land on standards and levels of living.

In 1930-1932, the outstanding three volume work, A Systematic Source Book in Rural Sociology by Sorokin, Zimmerman and Galpin, added a number of refinements to the developing frame of reference. 9 The chapter "Social Stratification of the Agricultural Population" treats two of the fundamental aspects of man-land relations, size of holdings and land tenure. Up to this time the two had been largely combined and treated as "land tenure." In this chapter six categories of farming enterprises are suggested with size as the major consideration. Also the agricultural population is divided into 13 tenure categories that range from the owners of large estates at

8 cf. Edmund de S. Brunner, Gwendolyn S. Hughs, and Marjorie Patten, American Agricultural Villages (New York: George H. Doran Company, 1927); and Edmund de S. Brunner, Village Communities (New York: George H. Doran Company, 1927).

9 Pitirim A. Sorokin, Carle C. Zimmerman, and Charles J. Galpin, A Systematic Source Book in Rural Sociology, (Minneapolis: University of Minnesota Press, 3 Vols. 19301932). 
one extreme to hired laborers at the other. Another important contribution of this work is the chapter "The Ecology of the Rural Habitat" which includes the paper written by Dr. A. Demangeon that has since become a classic description of rural settlement patterns. In this article the principal types of settlement, agricultural village and isolated farmsteads, as well as intermediate types, are outlined and examples are presented.

In this same year a monograph entitled the Mormon Village: A Study in Social Origins by Lowry Nelson appeared. 10 This also was a great step in the refinement of the study of settlement patterns. This same topic was carried even further by Terpenning in his extensive work Village and Open Country Neighborhoods. ${ }^{11}$ In the chapter, "The American Neighborhood," a vivid description of the isolated farmstead is presented. By comparing settlement patterns throughout the world, the developing frame of reference became broader in its application.

In 1933, Rural Social Trends by Brunner and Kolb appeared. 12 This was a portion of the report of the

10 Lowry Nelson, The Mormon Village: A Study in Social Origins, Brigham Young University Studies, Number 3 (Provo, Utah: Brigham Young University, 1930).

$11_{\text {Walter A. Terpenning, Village and Open Country }}$ Ne1ghborhoods (New York: The Century Company, 1931).

12 Edmund de S. Brunner and John H. Kolb, Rural Social Trends (Now York: McGraw-Hill Book Company, 1933). 
President's Research Committee on Social Trends which had resurveyed the 140 communities and 21 of the 26 agricultural counties studied earlier by the Institute of Social and Religious Research. The book deals with the same general aspects of man-land relations studied previously. The significance of this study here is that the people doing the field surveys were the ones who were later responsible for the refinement of the frame of reference for the systematic study of man and land. The survey was systematic, comparative and used measurable categories, all of which are to be found in the later studies of man and land.

In 1940 Smith published the first edition of his book, The Sociology of Rural Life. ${ }^{13}$ Here the tools for the study of the institutional relation of man to the land were first presented in the form that they are used in the present study in all aspects except "Systems of Agriculture." In the section, "Rural Social organization," specific chapters are found entitled: "Forms of Settlement"; "Land Division"; "Land Tenure"; and "Size of Holdings." In each chapter the categories are presented in a systematic way, justified as to their utility and applied to the then current situation in the United States.

\footnotetext{
13T. Lynn Smith, The Sociology of Rural Life (New York: Harper and Brothers, 1940).
} 
This is the first major work in which the topics, size of holdings and land tenure, are separated into distinct chapters. This separation adds greater precision to the frame of reference.

At this same time, and in the years that followed, there were a large number of books on rural sociology. In them the subject of man-land relations was one of the main considerations. In such books as: Rural Life in Process by Landis; ${ }^{14}$ Rural Sociology and Rural Social Organization by Sanderson; ${ }^{25}$ Rural Iife in the United States by Taylor and associates (this book has a large section, "Rural Regions," in which man-land relations are compared from region to region and the effect they have on levels of living); 16 Rural Social Systems by Loomis and Beegle; ${ }^{17}$ and The Study of Rural Society by Kolb and Brunner, all give attention to the subject. ${ }^{18}$

14 Paul H. Landis, Rural Life in Process (New York: McGraw-Hill, 1940).

15 Dwight Sanderson, Rural Sociology and Rural Social Organization (New York: John Wiley and Sons,

${ }^{16}$ Carl C. Taylor, et al., Rural Life in the United States (New York: Alfred A. Knopf, 1949).

17 Charles P. Loomis and J. Allan Beegle, Rural Social Systems (New York: Prentice-Hall, 1950).

$18 \mathrm{John} \mathrm{H}$. Kolb and Edmund de S. Brunner, The Study of Rural Society (Cambridge: The Riverside Press of Houghton-Mifflin, 1952). 
In 1952 Nelson published the book, The Mormon Village based on the monograph first written in 1930.19 The chapter, "Basic Patterns of Land Settlement" represents a much improved presentation over the earlier writings. This is but one example of how additional experience and the work of others have contributed to the refinement of the tools now available for the study of this topic.

One of the aspects of refinement of the frame of reference has been that of overseas application. During the 1940's an excellent opportunity was afforded by the assignments of those most interested in man-land relations in the United States, to Latin America and other countries. More details of this are given in the next section, "Works in Man-Land Relations in Latin America," but it is also of interest here. Comparative studies give further insights into a phenomenon and also serve to broaden the theoretical framework in which the phenomenon is viewed. As a result of overseas application, a new and important aspect of manland relations was added in the 1953 edition of Smith's The Sociology of Rural Life, that of "Systems of Agriculture."20 At this point, the basic frame of reference used in this dissertation became essentially complete;

${ }^{19}$ Lowry Nelson, The Mormon Village (Salt Lake City: University of Utah Press, 1952).

20 T. Lynn Smith, The Sociology of Rural Life, 3rd edition (New York: Harper and Brothers, 1953). 
It covered all five areas, specifying measurable categories in a systematic way; and it was applied to both regional and cross-cultural situations.

Works in Man-Land Relations in Latin America.

The studies of the institutional relationship of man to the land in Latin America did not follow the same steps as in the United States. Sociology as a discipline in Latin America was not empirically oriented in the early years and did not concern itself with the problems of a changing society. A number of scholars wrote about rural problems but they were largely novelists, journalists and historians. None the less, the works of men like Freyre and especially his Casa Grande e Senzala (The Masters and the Slaves), first published in 1933 in Portuguese, is a great addition to the study of man and land in Latin America. 21

North American sociologists had long been interested in Latin American societies. In 1915, Ross published South of Panama which was a vivid description of life in South America. 22 Both this book and a later one, The Social Revolution in Mexico were based on systematic

${ }^{21}$ Gilberto Freyre, The Masters and the Slaves (New York: Alfred A. Knopf, $1 \overline{946})$.

${ }^{22}$ Edward A. Ross, South of Panama (London: George Allen and Unwin, Ltd., I9́l5). 
observation during his travels. ${ }^{23}$ In chapters entitled "Labor," "Class and Caste," "Land Feudalism," and "Land Reform" he emphasizes the close association of man-land relations and the resulting societies of Latin America. Geographers added much to the systematic study of this same subject also. The works of McBride on Bolivia, Mexico, and especially, his Chile: Land and Society included both vivid descriptions as well as statistical information on the subject. 24 Later, Simpson's The Ejido: Mexico's Way Out added to the prior work of McBride. 25 A great step forward in the study of man-land relations in Latin America came when the same men who were most concerned with this aspect of rural society in the United States were invited to different countries of Latin America on official assignments. In 1935, Problems of the New Cuba: Report of the Commission on Cuban Affairs, was published. ${ }^{26}$ Zimmerman was the person commissioned to study rural life and he was able to apply the developing frame of reference for the study of man-land relations to

23 Edward A. Ross, The Social Revolution in Mexico (New York: The Century company, 1923).

${ }^{24}$ George M. McBride, Chile: Land and Society (New York: American Geographical Society, 1936).

25Eyler N. Simpson, The Ejido: Mexico's Way Out (Chapel Hill: University of North Carolina Press, 1937). ${ }^{26}$ Carle C. Zimmerman, et al., Problems of the New Cuba: Report of the Commission on Cuban Affairs (New York: Foreign Policy Association, 1935). 
the task. This was but the beginning. In 1942 and 1943 three rural sociologists (Smith, Taylor, and whetten) were sent by the U. S. Department of State to make sociological studies of rural life in Brazil, Argentina, and Mexico, respectively. Shortly after they returned, Nelson was sent to Cuba on a similar assignment. And soon thereafter, Leonard went to Bolivia as director of a cooperative agricultural experiment station, and in that capacity he made two studies of Bolivian rural communities, and eventually published a book-length analysis of rural society in Bolivia. By this time the frame of reference had been sufficiently developed that all five sociologists (Lowry Nelson, T. Lynn Smith, Carl C. Taylor, Nathan L. Whetten, and Olen E. Leonard) afreed on the general observational categories to be used in the studies. This gave an opportunity to make comparative analysis of the relations of man to the land in the different countries and also served to test the theoretical frame of reference. From these assignments a number of publications were forthcoming: Smith's Brazil: People and Institutions; 27 Taylor's Rural Life in Argentina; ${ }^{28}$ Whetten's Rural Mexico; ${ }^{29}$ Nelson's

27. Lynn Smith, Brazil: People and Institutions (Baton Rouge: Louisiana State University Press, 1946). ${ }^{28}$ Carl C. Taylor, Rural Life in Argentina (Baton Rouge: Louisiana state University press, 1948). 29 Nathan L. Whetten, Rural Mexico (Chicago: University of Chicago Press, 1948). 
Rural Cuba; 30 and Leonard's Bolivia: Land, People and Institutions. 31 As a result of these and other investigations by these men a number of monographs were also published: in 1945, Tabio: A Study in Rural Social Organization (Colombia) by Smith, Diaz, and Garcia; ${ }^{32}$ in 1947, P1chilingue: A Study of Rural Life in Coastal Ecuador by Leonard; 33 and in 1948, Canton Chullpas:

A Socioeconomic Study in the Cochabamba Valley of Bolivia and, Santa Cruz: A Socioeconomic Study of an Area in Bolivia, both by Leonard. 34 Particular aspects of manland relations in these and other Latin American countries were also considered in articles published in the journal Rural Sociology in the years that followed. 35

${ }^{30}$ Lowry Nelson, Rural Cuba (Minneapolis: The University of Minnesota Press, 1950).

3lolen E. Leonard, Bolivia: Land, People and Institutions (Washington: The Scarecrow Press, 1952).

32T. Lynn Smith, Justo Diaz Rodriguez and Luis Roberto Garcia, Tabio: A Study in Rural Soc1al Organization (Washington: Office of Forelgn Agricultural Relations, 1945).

33 olen E. Leonard, Pichilingue: A Study of Rural Life in Coastal Ecuador (Washington: Office of Foreign Agricultural Relations, 1947).

34 Olen E. Leonard, Canton Chullpas: A Socioeconomic Study in the Cochabamba valley of Bolivia (washington: office of Forelgn Agricultural Relations, 1948).

35 cf. John V. D. Saunderg, "Man-Land Relations in Ecuador" Rural Sociology (March, 1961). 
The significance of this investigution for the understanding of Latin American societies was considerable but its importance in the development of a frame of reference for the sociological study of the relation of man and land was even greater. The comparative nature of these studies reauired refinements in the concepts that resulted in even broader applicability than had been attained by the regional studies of Taylor and associates in the United States in 1949. 36

Special attention should be given here to the development of the study of systems of agriculture. In the systematic frame of reference presented by smith in 1940, this was not one of the parts. 37 Due to his work in Brazil, some of it is first presented in the chapter entitled, "Fire Agriculture" in the first edition of Brazil: People and Institutions. ${ }^{38}$ In the monograph he wrote on Tabio it was included as a major concept in the study of man-land relations. 39 Later it was included as such in the third edition of The Sociology of Rural Life as well. 40

36 Taylor, et al., Rural Life in the United States. 37 Smith, The Sociology of Rural Life, Ist edition. ${ }^{38}$ Smith, Brazil: People and Institutions, lst edition. ${ }^{39}$ Smith, Diaz, and Garcia, Tabio. 40 T. Lynn Smith, The Sociology of Rural Life, 3rd edition (New York: Harper and Brothers, 1953). 
With this refined instrument available, further studies have been made in Latin America and publications have resulted. In 1953, Turrialba: Social Systems and the Introduction of Change by Loomis and associates appeared; 41 in 1955, Man and Land in Peru by Ford; 42 in 1958, Land Reform and Democracy by Senior; 43 and in 1961, Guatemala: The Land and People by Whetten. 44 This frame of reference has also been used in dissertations written under Professor Smith's direction. In 1954, Schulman finished his work entitled, A Sociological Analysis of Land Tenure Patterns in Latin America. 45 In 1955, A Sociological Study of the Relations of Man to the Land

4lCharles P. Loomis, et. al. Turrialba: Social Systems and the Introduction of Change (Glencoe: The Free Press, $1 9 5 3 \longdiv { \text { . } }$

42 Thomas R. Ford, Man and Land in Peru (Gainesville: University of Florida Press, $\overline{1955) . ~}$

$4^{3} \mathrm{Clarence} 0$. Senior, Land Reform and Democracy (Gainesville: University of Florida Press, 1958).

44 Nathan L. Whetten, Guatemala: The Land and the People (New Haven: Yale Uni versity Press, 1961).

${ }^{45}$ Sam Schulman, A Sociological Analysis of Land Tenure Patterns in Latin America. Doctoral Dissertation. Gainesvilie: University of Florida, 1954. 
in Boyacá (Colombia) was completed by Fals Borda. 46 The same study was later published in book form in spanish as, El Hombre I La Tierra en Boyacá. From previous research Fals Borda has also written Peasant Society in the Colombian Andes. 47 In 1967, a dissertation by clements considered the specific aspect of systems of agriculture in Brazil. 48 A number of recent works by Latin American sociologists have included man-land relations in their writings. Besides those of Fals Borda are: Sociología Rural by Solari; 49 Sociología y Desarrollo Rural by Arce; 50 Sociología: Introdución a su uso en Programas Agrícolas

46 Orlando Fals Borda, A Sociological Study of the Relations of Man to the Land in Boyacz. Unpublished dissertation. TGinesville: University of Florida, 1955).

47 Orlando Fals Borda, Peasant Society in the Colombian Andes (Gainesville: University of Florida Press, 1962).

48 Harold M. Clements, A Sociological study of the Mechanization of Agriculture in Minas Gerais, Brazil, unpublished dissertation (Gainesville: University of Florida, 1966).

49 Aldo E. Solari, Sociología Rural Latino-Americano (Buenos Aires: Editorial Uníversitaria de Buenos Aires, 1963).

$50 \mathrm{M}$. Antonio Arce, Sociología y Desarrollo Rural (San Jose: Lehmann, 1961). 
Rurales by Alers Montalvo; 51 and Sociología de Vida Rural by Hernani de Carvalho. 52

With the growing concern for agricultural development in Latin America, there is need for tools to analyze rural society. In recent years the Committee for Agricultural Development (CIDA) has incorporated this general frame of reference in their studies and found it to be useful. .53

The latest refinements of this frame of reference, interestingly enough, have come about in a Latin American setting. In 1967, the monograph, The Process of Rural Development in Latin America and the book, Colombia: Social Structure and the Process of Development, both by Smith, represent this refinement. 54

$51_{\text {Manuel Alers Montalvo, Sociología: Introdución }}$ a su uso en Programas Agrícolas Rurales Turrialba: Editorial $\overline{\text { SIC, 1960). }}$

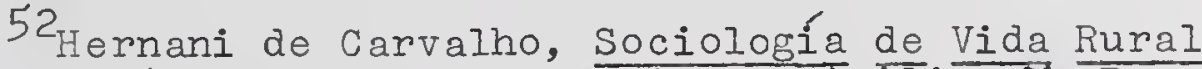
Brasileira (Rio de Janeiro: Editora Civilizaçă Brasileira, 1951).

53 Pan American Union, Central America (Washington: Inter-American Committee for Agricultural Development, no date).

54 T. Lynn Smith, Rural Development in Latin America (Gainesville: University of Florida Press, 1967) and T. Lynn Smith, Colombia: Social Structure and the Process of Development TGainesville: University of Florida Press,

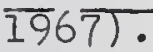


The Study of the Relations of Man and Land in Nicaragua.

There have been no prior sociological studies of the institutional relationship of man to the land in Nicaragua. None the less, some or parts of man-land relationships have been considered by geographers, historians, journalists, and land economists in their writings. Descriptive accounts of rural life in general are found in the early works: Travels in Nicaragua (1857) by Scherzer; ${ }^{55}$ The States of Central America (1858) by Squier; ${ }^{56}$ Historia de Niceragua by Gamez; ${ }^{57}$ Nicaragua by Levy; 58 and Documentos para la Historia de Nicaragua edited by Veea Bolaños. 59

A closer approximation to the systematic study of man-land relations can be found in more recent studies made principally by economists. In Plan Nacional de

${ }^{55}$ Carl Scherzer, Travels in Nicaragua, Vol. I (London: Longman, Brown, Green, Longman and Roberts, 1857).

$56_{\mathrm{E}}$. G. Souier, The states of Central America (New York: Harper and Brothers, 1858 ).

57 José D. Gamez, Historia de Nicaragua (Managua: El País, 1889).

${ }^{58}$ Pablo Levy, Nicaragua (Paris: Librería Española de E. Denné Schmidt, 1873).

${ }^{59}$ Andrés Veqa Bolaños, Documentos ara a Historia de Nicaragua, Tomo Primero. (Madrid: Ministerio de Educación de la República de Nicaragua, 1954). 
Desarrollo Económico y Social de Nicaragua (1965-69) published by the Nicaraguan government, a systematic study was made of the economic aspects of rural life in Nicaragua and the resulting levels of living. ${ }^{60}$ Mainly considered here were land holding and occupational categories of the rural population. Even prior to this, the International Bank for Reconstruction and Development published a report entitled Economic Development of Nicaragua in which categories and classification were used to study farm size, land tenure, and levels of living. 61 Because of a preoccupation with agrarian reform, a comparative study was made by the United States Operations Mission in which some standardized criteria were used to compare Nicaragua's agrarian structure with those of other Latin American countries. 62 In another comparative study done by the Proyecto Interamericano de Desarrollo Rural, different categories of land tenure as generally considered by land economists were used to

60 República de Nicaragua, Plan Nacional de Desarrollo Económico I Social de Nicaragua 1965-1969, Parte I (Managua: Oficina de Planificacion, 1965).

${ }^{61}$ International Bank for Reconstruction and Development, The Economic Development of Nicaragua (Baltimore: The Johns Hopkins press, 1953).

62 United States Government, Latin American USOM Seminar on Agrarian Reform (Vashington: International Cooperation Administration, 1961). 
compare Nicaragua to other countries. 63 These same categories were used by Maturana in his investigation "Land Tenure."64 He used three basic categories for analyzing farm size and separated the tenure groups into farm owners and farm laborers. This study was of comparative nature, including all five countries of Central America. A more detailed study was done by Blandon in his master's thesis in agricultural economics entitled "Land Tenure in Nicaragua." 65

Finally, the two closest approximations to the frame of reference used in the present study that have been done in Nicaragua are to be found in the works entitled, Central America prepared by the Inter-American Committee for Agricultural Development 66 and, Nicaragua: Características Generales de Ia Utilización y Distribución de Ia Tierra, a preliminary paper by the Food and Agricultural Organization. 67 In both of these studies specific categories have been used for the analysis of the size of

${ }^{63}$ Louis E. Heaton, Rural Development in Latin America (New York: American International Association for Economic and Social Development, 1963).

64 Egbert de Vries, Social Research and Rural Iife in Central America, Mexico and the Caribbean Region (Paris: United Nations Educational and Scientific Organization, 1966).

65 Alfonso Blandon, Land Tenure in Nicaragua, unpublished master's thesis (Gainesville: University of Florida, 1952).

66 Pan American Union, Central America.

67United Nations, Nicaragua: Caracteristicas Generales de la Utilización y Distrîbución de la Tierra (Mexico City: Food and Agriculture Organization, 1967$)$. 
farms and tenure groups. The latest census data have been used and cross tabulations have been made. Very little, if any, reference is made to the other institutional aspects of the relations of man to the land, such as settlement patterns, systems of agriculture and land division systems. Some reference is made to resulting crop yields and levels of living in the rural areas. 


\section{CHAPTER III \\ SIZE OF TRMA}

In an investigation of the size of farms one must seek to discover the manner in which the ownership and control of the land are distributed amons those who depend upon sfriculture for a livelihood. To accomplish this, a clear distinction as to what constitutes a farm is necessary, and an accepted unit of measurement must be emplojed. For the purpose of this study, a farm is a tract of Iand that is owned or operated as a productive unit bJ one person or a corporate entity; it is also assumed that one or more persons are involved in the enterprise and that the production is of sufficient value to provide the major part of the livelihood for at least one family. The unit of measurement most comon in Nicaragua is the manzana and is used irstead of the acre or hectare. ${ }^{1}$

Size of farms is the most important factor in the relationships of man and land. Power and prestige vary with the amount of land that an individual controls, so that extent of land ownership has social as well as economic consequences. This subject is not merely of

\footnotetext{
Ione manzana 0.7 hectares 1.7 acres.
} 
recent concern but has been important throughout history. The extent to which the ownership and control of the land has been vested in a few hands has been a major problem in many parts of the world since the days of Hammurabi. Latifundium is a word that has been used to describe the concentration of landholding, and it generally has undesirable connotations. This term was first used in connection with the "broad estates" (Iatus fundus) observed in the Roman Empire in about $80 \mathrm{~B} . \mathrm{C}$. As a result of military conquests and slavery, large tracts of land were taken over by officials of the empire. In the historical writings, there are many vivid descriptions of the contrasting conditions of life for the favored few who controlled the land and for those who perfomed the labor. 2

With the breakdown of the Roman Empire and centralized power, a new type of large landholding -- the feudal manor -- emerged. The peasants gradually lost all rights to the land when they attached themselves to a strong lord for protection. The contrasting conditions of lord and serf, or colonus, were not unlike those of master and slave in the Roman Empire. 3

p. 493.

2cf. Encyclopaedia Britannica, 1949 ed., Vol. 11,

3J. Ackeman and Marshal Harris (eds.), Family Farm Policy (Chicago: University of Chicago Press, 1947), 
As commerce began to bring light to the Dark Ages, a new type of large landholding emered as a result of the conquest and colonization of the New Horld. This was the plantation, characterized by largeness, reliance upon slave labor, foreign capital und management, and production for export purposes. The sharpness of contrast between the style of Iife of the plantation owners and manasers and that of the laborers even surpassed that prevailini on the roman latifundium and the feudal minor. 4

The plant tions of the southern United atates have had many of the characteristics of the landed estates of past history. Ir other countries throughout the vorid, the concentration of land in the hands of a privilejed few has been the focal point of wars and revolutions, including jome of those presentIy in promess. In Latin merica many of the sociul problems of today can be uttributed to the corcentration in the omership und control of the lund. areut contrasts in the size of forms ard the resulting rurcl societies hare been ohserved in the twentieth century. For exmple, in the plentotion areas of the southern Inited states, the situition is in sharp contrast with the wry of life I lnew personally as a jouth in a

4Iác c. Greares, "Pluntotions in Vorld Tconomy," in

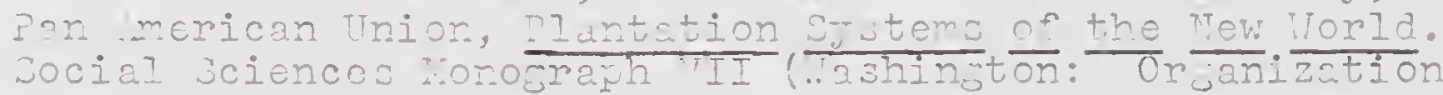
of American states, 1259), pp. 13-74. 
farmine community in the midwest. In the latter, all of the members of the community simultaneously were owners, managers, and laborers on their farms. As I have traveled. about in Latir America, I have observed the same separation between landowner and laborer that I had known in the South. The following paragraphs from my journal illustrate this matter:

(Oriente, Cuba, January, 1952) As far as the eye can see, the land belongs to one sugar company. There are approximately 500,000 acres here that stretch from bejond the bay to the mountain range behind. The workers live in small villages dotted about the plantation and often in barracks, one door per family. Some say that they can barely earn enough during the harvest season to pay for the food they have received on credit from the company store durine the dead season.

(The Dominican Republic, October, 1962) The road from Santiago to lloca started out as an excellent hichway but all at once became a rough country road. The only explanation that I can find is that the good part goes only as far as the entrance to the coffee plantation of Sr. T.

(Southern Chile, April, 19,62) The visit with Don J. at the Fundo I. was most interesting. The fundo has about 2,500 acres in all and over a hundred inquilinos (asricultural laborers). The house is an English-type mansion and the grounds are well landscaped. It is a ereat contrast to the workers' houses that I visited yesterday. Don J. was a gracious host. Both he and his brother-in-law discussed freely their fear of losing their land if the wrong party should be elected in the coming elections. 
They admit that somehow the lot of the inquilinos has to be improved but don't feel that acrarian reform is the answer.

In an analysis of the similarities and differences betweer tio sreat over-all rural systems, T. Iynn Smith has attempted to systematize the movledge available on the size of fams. Ile has focused attention upon the effects of large farms in comparison with those of familysized fams. According to him, the following are associated with the dominant position of large farms: (1) a hich decree of social stratification with a clear class separation between the landomers and the laborers; (2) little vertical social mobility so thit the "agricultural Iadder" cannot function; (3) caste as an important factor Wich can be an interited social position passing from one seneration to the next; (4) low kverage intellicence, and particularly low levels of literucy and school attendance; (5) restricted development of personality, with only a selected fer equipped with the social sraces considered us a minimum necessit; for the twentieth century; (6) onder-obey perzonal relations that are more alin to a mister-slave relationship than thut between equals; (7) the cll-importarce of routine, wth little application of new sl:ili s to the job; (8) a belief that manual labon is degrding and sonethinj to do only if necessary and to oucape if possible; (9) low levels and stardards of livino that can be observed in both hes lth and education; and 
(10) little incentive to work and save, coupled with a fatalistic attitude toward life and the future. 5

In contrast, a rural society based on family-sized farms is characterized by the opposite situation in each of the ten points mentioned above. It is basically equalitarian and progressive, making for efficient use of both human and natural resources. It permeates not only rural society but all aspects of national life and gives a firm foundation to build the future on.

\section{Classifications of Farms}

For some purposes it is useful to divide farms into three categories: small, medium, and large. The distinction is based on the area involved in the farm. Generally, small farms are those under five hectares, medium are from five to 49 hectares, and those of 50 hectares or more are considered as large farms.

This distinction based on physical size alone is inadequate from many points of view. In some instances, the excellent natural environment of a small plot will allow production surpassing that of a much larger tract. Also, if large amounts of capital are used for materials and equipment, a highly intensive operation can be carried on.

5T. Lynn Smith, Colombia: Social Structure and Process of Development (Gainesville: University of Florida Press, 1967), pp. 8-24. 
Whether a farm should be considered large or small also depends on the type of farming that is employed. For example, the production of fresh vegetables for the market is highly intensive, and the economic product per unit of land area is high. Cattle raising on unimproved pasture is an example of an extensive type of enterprise, and both the inputs and outputs are lower per unit of land area. A more adequate classification of size of farms, then, should make some allowances for the natural capabilities of the land to produce and the type of farming employed. There is one further factor that must be considered in the selection of categories for use in the classification of farms. This might be called the entrepreneur factor, and probably it is the most important of all considerations. An optimum size of farm would be that which could make efficient use of the capital, the managerial ability, and the physical labor of a farmer and his family. This can be further illustrated by looking at the three specific categories.

Small farms are sometimes called minifundia, or subsistence plots. Usually the quantity produced on this type of farm is far below that necessary to sustain a family. Therefore, unless the family income is supplemented from other sources of employment, the level of living is extremely low. In Latin America these small plots (minifundia) are found commonly to adjoin the extremely large farms, where periodic work is available. These small farms are likely to be found on the hilly 
lande that are left orer and not suitable for larse-scale plantinjs on crazins. This land is often occupied without clear title or under an arrangement with the large landowner, so that permanent improvements are not considered a good investment. Small fams in Nicarasua can best be described as those under five manzanas. In spite of the inadequacies of a classification based on area alone, this sives a startins point from which adjustments can be made.

lieaium-sized farms are also referred to as familysized farms. In their ideal type, these are found in northwestern تurope and in midwestem United States. They are not common in Latin America. In this size of farm, the entrepreneur factor operates most effectively. It is here that the capital, the management skills, and the physical labor of the farm family combine to give maximum output per unit of input. The actual physical size is difficult to detemine, for constant innovation is a characteriatic of the family-sized farm. As mechanization and other applications of technolosy are made, the size may increase from 50 to 500 acres, while the farm still uses only family labor with an occasional hired hand to help. There are few instances in Nicarasua of this ideal type. The closest catesory (and that which will be used in this classification) pertains to those units from 5 to 49 manzanas in size. 
Large farmi are sometimes culled latifundia, althou ih the two terms are not completely sunonjmous. Latifundia is the tem usualiy used to describe the extremely lare farms on which little, if any, attempt is rade to make an intensive use of the land. It is the contemporary lare farms which involve the concentration of land ownership described in the introductory pararraphs of this chapter. Or these large tracts of land that are owned and operated by fer individuala or corporate entities, there is a division of function, vith owners and operators hiring asricultural laborers to perform the physical work. Production is often limited to one specialty, such as cotton, sugar, or cattle. These large holdinss are exemplified bJ the plantations, the ruciendas, the fundos, the fazendas that are found throuchout Latin merica. Tor the purposes of classification of fams in ticaragua, all holdinss from 50 to 2,499 manzanus are considered as large farms. apecial attention is Given to the farms of 2,500 manzanas and over, for these most nearly possess the characteristics of Iatifundiu.

zize of Farma in Nicarasua

In Ticaragua's 1963 censos "acionales: Eropecuario, the arricultural unita are called Unidades de Zuplotoción irocecuario. These include: 011 land used totally or partially for asricultural or cattle production, that 
owned by the producer, that rented by him or that he is enabled to use by any other tenure arrangement, and that Which is under his administration though it is in more than one tract as lonj as it is in adjoining comarcas (the smallest political units). It does not include any land that has been siven by the owner to others through a rental or any other tenure arrangement for the agricultural year 1962-63.

As it is defined above, not every explotación agropecuario can be classified as a farm. For this reason, the term "farm" will be used only when the explotación in question conforms to what is commonly understood to be a fam. 6

There was a total of 102,201 such explotaciones in Micaracua in 1963. Altogether 5,461, I62 manzanas are represented in these units, and this accounts for approximateIJ one-fourth of the total land area of the Republic.? If all establishments were equal in size, there would be slightly over 53 manzanas in each of them. Such is far from the case, as can be noted in Table 1 . Of particular interest are the number of establishments and amount of

6Repúbica de ricaragua, Censos racionales 1963: Agropecuario (Managua: Dirección General de Estadistica ycensos, 1966), p. xi.

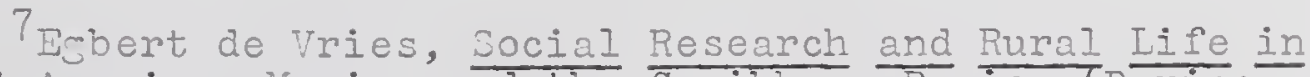

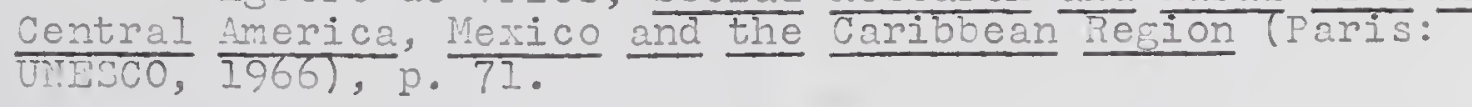


TABLE 1

SIZE OF THE EXPLOTACIONES AGROPECUARIOS

IN NICARAGUA, 1963

\begin{tabular}{lcccc}
\hline $\begin{array}{c}\text { Size of } \\
\text { Explotaciones }\end{array}$ & \multicolumn{2}{c}{ Explotaciones } & \multicolumn{2}{c}{ Area } \\
\cline { 2 - 5 } & Number & Per Cent & Manzanas & Per Cent \\
\hline Under 1 & 2,258 & 2.2 & 1,328 & \\
1-4.9 & 33,948 & 33.2 & 83,042 & 1.5 \\
\hline Under 5 & 36,206 & 35.4 & 84,370 & 1.5 \\
\hline $5-9.9$ & 15,730 & 15.4 & 105,728 & 1.9 \\
$10-19.9$ & 13,273 & 13.0 & 173,976 & 3.2 \\
$20-49.9$ & 14,703 & 14.4 & 440,159 & 8.1 \\
\hline $5-49.9$ & 43,706 & 42.8 & 719,863 & 13.2 \\
\hline $50-99.9$ & 10,949 & 10.7 & 678,970 & 12.4 \\
$100-199.9$ & 6,291 & 6.1 & 768,633 & 14.1 \\
$200-499.9$ & 3,554 & 3.5 & 961,015 & 17.6 \\
$500-999.9$ & 920 & 0.9 & 583,736 & 10.7 \\
$1000-2499.9$ & 405 & 0.4 & 563,303 & 10.3 \\
\hline $50-2499.9$ & 22,119 & 21.2 & $3,555,657$ & 65.1 \\
\hline 0 ver 2500 & 170 & 0.2 & $1,101,272$ & 20.2 \\
\hline Tota1 & 102,201 & 100.0 & $5,461,162$ & 100.0 \\
\hline
\end{tabular}

Source: Compiled and computed from data in República de Nicaragua. Censos Nacionales 1963: Agropecuario. (Managua: Dirección General de Estadística y Censos, 1966). 
land in each category of the same: small (under five manzanas), medium (from 5 to 49.9 manzanas), Iarge (from 50 to $2,499.9)$, and the latifundia $(2,500$ and over). (See Table 1.)

More than one-third of all units in Nicaragua contain less than five manzanas apiece. The mean size of these small establishments is 2.4 manzanas. Some of these are small quintas (country homes for those working in the cities), but most of them are subsistence plots used by the agricultural laborers. Nany of these small units are true minifundia. The following extract from my travel notes gives some of the facts about a few of them.

(Iarch 22, 1966, Los 1.Itos) Los iltos is a village of workers in the middle of the cotton ilelds. One of the large cotton processinc plants is nearby, and some work at them as well as in the fields. Nost of the people Iive here pemanently but are entirely dependent on cottor. Iach house has a small plot with some corn, some yucca (casava), and other plantings for household use. I number of pigs ire to be seen wandering about.

lore thar two-fifths of the farms are of medium size, Jet the amount of land represented is comparatively smil (only 13.2 per cent). The mean size of these establishments is only 16.5 manzanzs.

It would be hard to determine just how many of these units should be considered as family-sized farms. Noreover, this will vary to some extent with the area of the country involved and the capabilities of the land. The 
family-zized frm does exist, however, as on re seen from some of my field notes triren in the Insuna area:

(Mnrch 21, 195', Ia Incuna) The icricultur-I Extension has worked clovely with this community for a number of years. The people have ilways shown more response and se eager to learn. Upon leaving the hichway I noticed a new sower line being erected. Some of the young men were helping in the clesring of the trees and brush. This was one of the first communities to orjanize an electric cooperative and raise the necessarm amount of money to start the project. The people of La Laguna do not live in close villare clusters but live on their small farms. Upon arrival in the certer of the community, I found the Extension isent helpin the Fublic . Iealth workers in a school vaccination project. They were also in the process of installing a number of toilets. The community or oanization was eager to start adult literacy classes and had already inwested in books for 40 pupils. The agents were proud of the progress being made.

Dy focusing attention upon the large establishments, one observes that two-thinds of the asricultural land of Ticaragua is embraced within the limits of only one-fifth of the explotaciones. The number of proprietors of these large estates, thourh, undoubtedly is considerably less than the ficure of 22,119, siven in Table 1, because many of the most affluent proprietors own not one but sereral separate and distinct lirge landed estates. This reprewents a considerable concentration of landholding. in example of life on one of these lare establishments is commented upon in the followine extract from my field notes:

(Narch 8, 1966, Santa Cruz) There are no permanent houses here and no real village. The 
scattered houses are no more than temporary shelters because the land rental arrangements do not allow any permanent buildings. In the first school survey it was found that only two people in this area could read and write. SIightly over 2,000 people live here.

I talked at length with Don F. about the cotton crop and how he became involved.... He had started as an agricultural laborer and certainly looks or lives no differently from the field hands that worls with him in the crop. He said that most of the land in the area was worked under the same rental arrangement that he has. He did not say who the landowner was.

Special attention must be directed to the explotaciones containino more than 2,500 manzanas. mhese are not included in the large-establishment class for they seem to represent a special case. On these immense Ianded estates, little attempt is made at intensive cultivation of the land, if it is cultivated at all. The tem latifundia best applies to this category. There is a Greater concentration of ownership and control of the land here than in the category of larse establishments. Huch of this land is devoted to cattle grazing, as in the case of the areas around LI Salto. Mfain, my field notes are illuminating:

(El Salto, December 14, 1964) This evening I talked with Don A. for over two hours. He and his associates are large landowners in the area. He has 900 head of cattle at this time. Ve discussed cattle problems and new waJs of treating diseases.... He has a sovernment post and enjoys workins with cattle as a sideline. 
Then 311 of the exploticiozes of 50 manzanas and orer are added tomether, it is found that 85.3 per cent of the land is controlled by 21.4 per cert of the holders. comsidenirs those units of 200 manzanas nnd ower, only 4.0 per cent of the operatora control 59.8 per cent of the Iind. These figures do not represent land ounership, and it is lirely that many who were operating the land at the tire of the census had no more than a seasonal Iease arnonsement with the owner. If figures were arailble to indicate land ormerahip, there is every reason to beliere that they would show an even hisher concentrution of control of the land than that irdicated by the data ji:en in mable 1 .

\section{The Hinisterio de Zconomín (Hinistry of Jconomics)}

incluces foctors other thin aize in its classification of emplotaciores auropecuarios. Mhe "zinistnt adjusts for location, twe of fumin, Ievel of tecinoloj, und mention to mankets. In comparirj the results of its complation Holl. those publishek by the linistry of . uriculture, it nas formd that there are 77,235 , insted

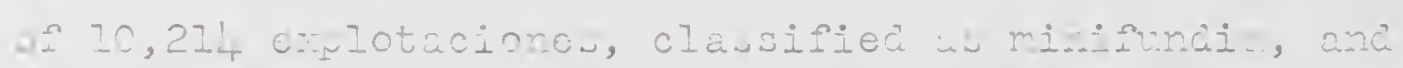

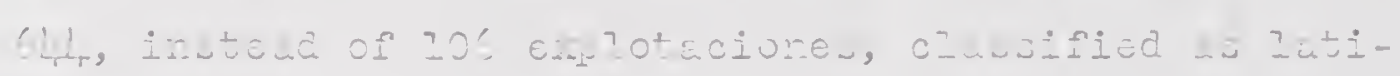

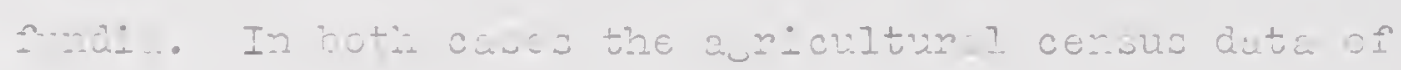


1957 were used as a basis for calculations. ${ }^{8}$ This reclassification indicates that the concentration in ownership and control of the land in Nicaragua is even higher than is indicated by the data as they are usually presented.

Regional Comparisons

There are three natural regions in Nicaragua, and the 1963 census data can be combined so as to provide information for each of these divisions. There are 5,461,162 manzanas of agricultural land in the Republic as a whole, distributed as follows: 1,823,904 manzanas in the seven distritos (provinces) comprising the Pacific region; 2,880,725 manzanas in the seven distritos which make up the North-Central region; and 756,533 manzanas in the two distritos which form the At lantic region.9

See Table 2, which gives the per cent of the explotaciones and the per cent of land in each of the size categories for each of the regions.

The Pacific region has a higher proportion of minifundia and also of latifundia than either of the

8 Alfonso Blandon, Land Tenure in Nicaragua. Unpublished master's thesis. Gainesvilie: University of Florida, 1962.

${ }^{9}$ República de Nicaragua, op. cit., pp. xiv-xvi. 
RELATIVE IMPORTANCE OF VARIOUS SIZES OF EXPLOTACIONES AGROPECUARIOS BY GEOGRAPHICAL REGIONS IN NICARAGUA, 1963

Size

(manzanas)

Republic

Pacific

North

Central

Atlantic

Under 5

Per cent of

holdings

35.4

44.3

30.0

32.2

Per cent of area

1.5

2.0

1.4

1.0

$5-49.9$

Per cent of

holdings

42.8

43.5

43.7

35.2

Per cent of area

13.2

13.2

14.6

$7 \cdot 7$

50-2499.9

Per cent of holdings

Per cent of

area

21.2

11.9

26.2

32.4

65.1

54.2

73.1

60.8

Over 2500

Per cent of holdings

Per cent of area

0.2

0.3

0.1

0.2

Total

$$
P
$$

Per cent of holdings

Per cent of area

20.2

30.5

10.9

30.5

Source: Compiled and computed from data in República de Nicaragua. Censos Nacionales 1963: Agropecuario. (Managua: Direccion General de Estadística y Censos, 1966). 
other rejions. Some of the small plots are those belonjins to people who work in the urban centers but use the land to supplement their incomes; in other cases, thej are used by upper-class families as small country estates. The Pacific region also has fewer large units than the other regions, but they account nonetheless for over 54 per cent of the land area. Then alI of the estabIishments over 50 manamas are grouped, 84.7 per cent of the land area and only 12.2 per cent of the tracts are accounted for. The Pacific region has the most intensive agriculture and highest density of population in "icicaragua, but there still is considerable concentration in the ownership and control of the land. Blandon found that "the existence of latifundias in close proximity to a large number of minifundias is typical" in this western region of Iicaragua. 10

The outstandin。 characteristic of the Torth-Central region is the relatively high percentage of medium and large units. This is true onlj relative to the situation in the other zones, for onlJ 14.6 per cent of the agricultural land is in establishments of medium size. If all units over 50 manzanas are considered together, 84.0 per cent of the asricultural land of the Iiorth-Central zone

10 Blandon, op. cit., p. 61. 
is accounted for. It is hard to detemine just how marj of the medium-sized establishment a can be considered as fumizy-sized fams, but, because of the type of agriculture, the topocraphy, and the lack of a complete road networls, it is probuble that this zone has a higher proportion of such farms thin the other regions.

$\therefore$ further observation can be made in relation to medium-sized units. If the cut-off point vere moved up to 500 manzinas, then the medium-sized establishments .ould iccount for 67.0 per cert of the anricultural lund area in the rejion. In some csaes, a 500-manzann estabIishment could atill be considered a frmily cprration. In a coffee plantetion, bowerer, which also is common in such ureas, even 50 moxzanas rould be too linge for one family to harale without the rezular hely of severcil arricultural laborers. To determine the ctual number of f-milj-sized frms, it would ke nocessan- to use the factors suosested bu the liniuterio de Iconomí es nell to ence in considerable cureful obsemution in the resion itself.

The itlantic is the Ieust dereloped and mozt

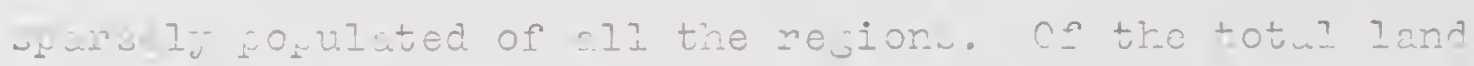

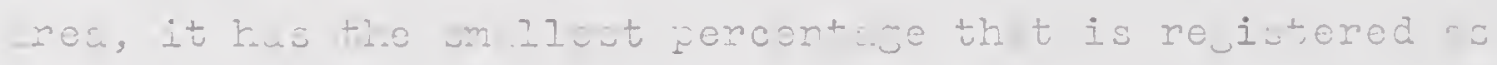
noriculturn? Iand. Mre outstancing fecture here is the amall ares in eatoblishments of leas thar fo monamnui. onl." Q.7 per cent of the soricultunn land is found in 


\section{8}

the categories of small and medium units. At the other extreme, 91.3 per cent of the land is found in explotaciones of more than 50 manzanas.

\section{Size of Explotaciones and Land Use}

The land area of ricaragua has never been used at a level approaching its agricultural capabilities. In a study made by the International Pank in 1952, it was estimated that only 25 per cent of the potentially arable land was beine used. II Blandon summarized the data from the Food and Agriculture Organization of the United Nations and the Ticaraguan Arricultural Survey of 1958 and found that only approximately 13 per cent of the land area could be considered as cultivated amricultural land. This was an increase from 7 per cent in 1949. He also calculated that an additional 18 per cent was suitable for farming but was not being cultivated; 45 per cent was in forest; 9 per cent was in cities, roads, and so on; and 15 per cent was not susceptible to use. ${ }^{12}$ A report on agricultural development in Latin America by the American

11 International Bank for peconstruction and Development, The Economic Development of $\frac{\text { Ticaragua (Baltimore: }}{\text { The Johns Hopkins press, I953) }}$

12 Blandon, op. cit., p. 33. 
International sssociation sare a sliutly higher fiovre of 16.2 per cent for the portion of arricultural land. 13 Fortunately, the census of 1963 gites specific dat about the amount of land that is considered as acricultural. Thiz comprehensive irventor placed ๆ461,162 manzanus in this catejory, a figure equal to sproximately 25 per cent of the total land area of the Poputic. 14

mhis census also contrins n classification of the uses of arricrltural land into the followino seren catecories:

1. cinnual crops (cultivos anuales): arable Iand in seasonob7e crops and successive crops of less than one year. 2. Permanent crops (cultivos permanentes) :
crops of lonfer duration thit do not need replanting after each hurvest, not includino forest and pastures.

3. Fallor Iand (tierras en descanso): arable land not planted durinc the $2952-63$ season but that his been used during tho last sive yerrs.

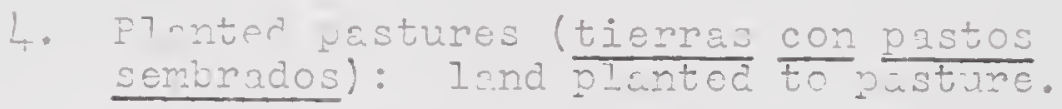

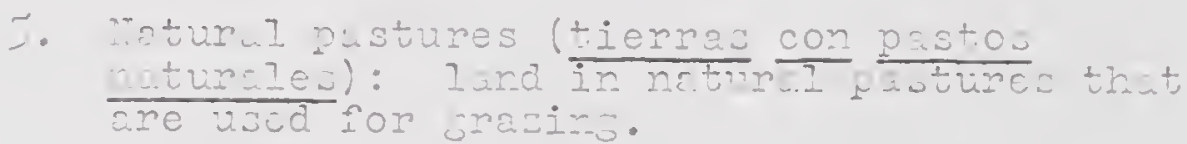

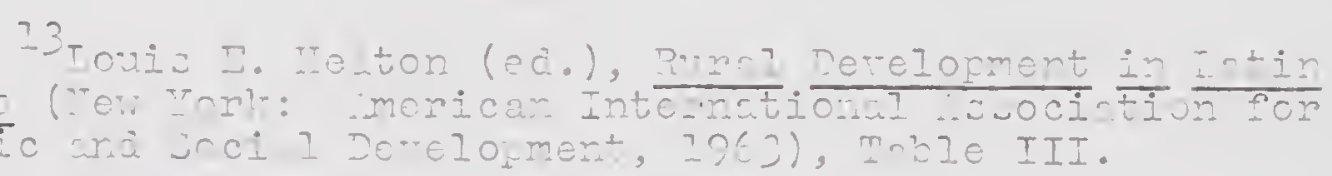

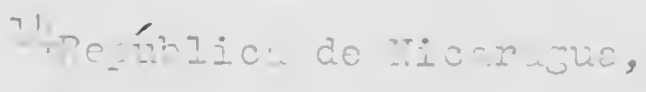




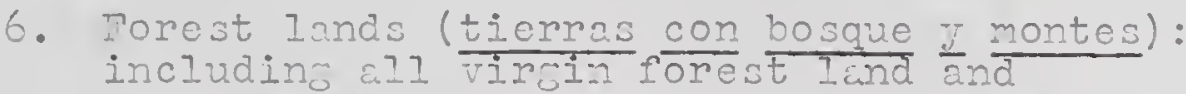
second groluth which is potentially asricultural land but has not been planted in the last five jears. 7. Other lands (otras tierras de $\frac{\text { ta }}{\text { ción): land occupied by buildings, roads, }}$ stramps, etc., not actually usable for cyltivation but part of the actual holdins. 15

For the purposes of this study, three main categories are used: crop land (combining 1, 2, and 3), pastures (combining 4 and 5), and forest (combining 6 and 7 ). Table 3 shows how the proportion of the agricultural land belonging in each of these varies from one region to another. As can be observed, even in the region of highest agricultural intensification (the Pacific), crop land accounts for less than 25 per cent of the total. Almost half of the asricultural land in the Pacific and TorthContral regions is pasture land. As can be expected, forest lands account for over half of the relatively undeveloped Atlantic resion.

of particular interest is the land use according to size of the establishments. (See Table 4.) In the smaller tracts, crop land is most important. In the largest establishments, pasture land predominates.

Several relationships between the size of the explotaciones and land use stand out. Specifically, as the size

I5 Ibid., p. xviii. 


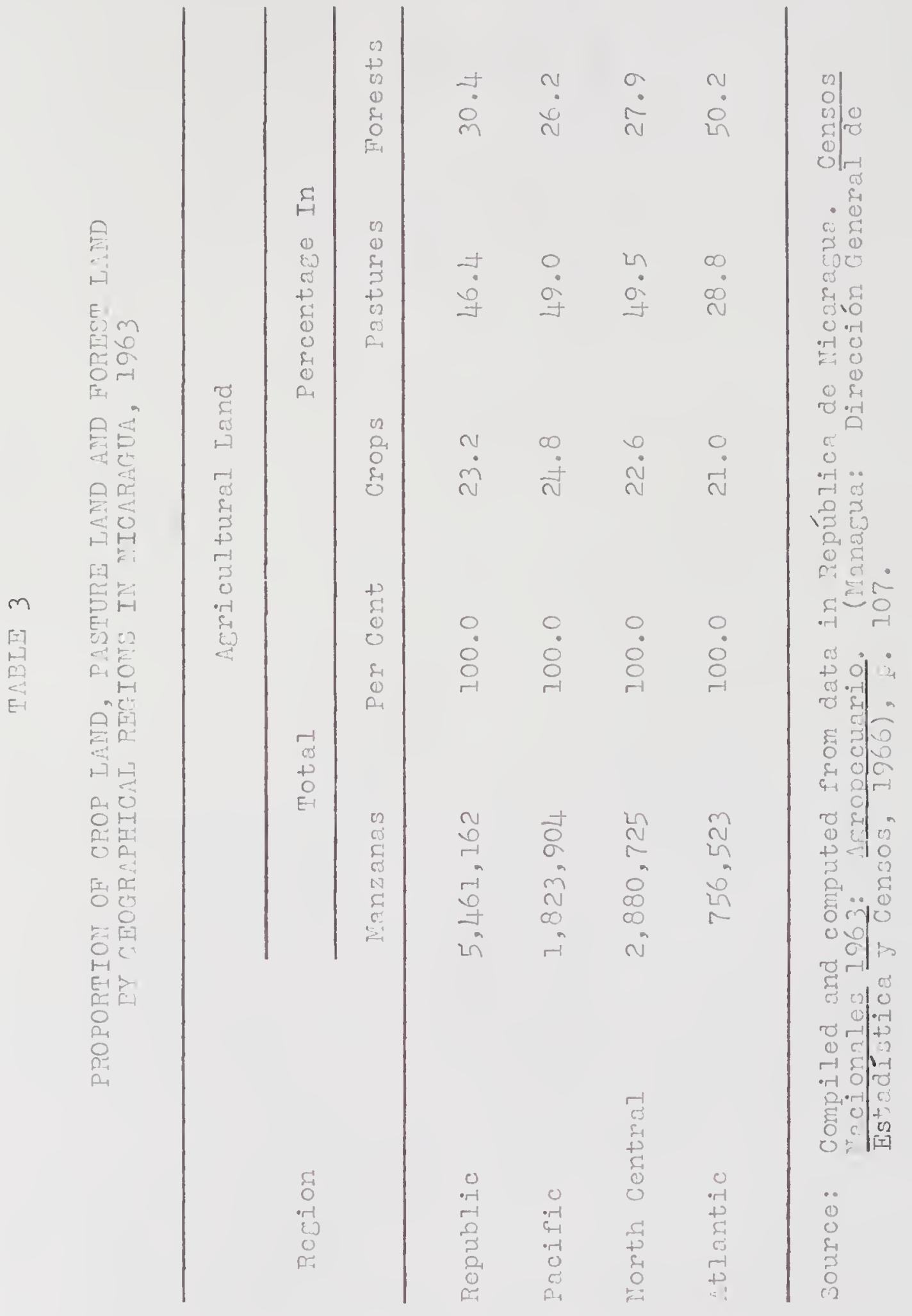


TABLE 4

RELATIVE IMPORTANCE OF CROPLAND, PASTURELAND, AND FORESTLAND IN NICARAGUA BY SIZE OF EXPLOTACIONES AGROPECUARIO, 1963

\begin{tabular}{|c|c|c|c|c|c|}
\hline $\begin{array}{c}\text { Size of } \\
\text { Explotaciones } \\
\text { (manzanas) }\end{array}$ & $\begin{array}{c}\text { Area } \\
\text { (manzanas) }\end{array}$ & $\begin{array}{l}\text { Cropland } \\
\text { (per cent) }\end{array}$ & $\begin{array}{l}\text { Pastureland } \\
\text { (per cent) }\end{array}$ & $\begin{array}{l}\text { Forest land } \\
\text { (per cent) }\end{array}$ & $\begin{array}{l}\text { Total } \\
\text { (per cent) }\end{array}$ \\
\hline Under 5 & 84,370 & 75 & 15 & 10 & 100 \\
\hline $5-49.9$ & 719,863 & 42 & 38 & 20 & 100 \\
\hline $50-2499.9$ & $3,555,657$ & 23 & 46 & 31 & 100 \\
\hline 2500 and over & $1,101,272$ & 6 & 57 & 37 & 100 \\
\hline Republic Total & $5,461,162$ & $23+$ & $46+$ & $30+$ & 100 \\
\hline
\end{tabular}

Source: Compiled and computed from data in República de Nicaragua, Censos Nacionales 1963: Agropecuario, (Managua: Dirección Genera 1 de Estadistica y Censos, 1966), PP. 107-112. 
of the estrblishment incresses: (1) the prorortion of crop land decreases; (2) the proportion of pasture increases; and (3) the amount of unused land (forest land, and so on) increases.

As is to be expected, land dedicated to specific crops varies according to the size of the farm. Thus, approximately 60 per cent of the corn, 60 per cent of the beans, and 50 per cent of the rice are produced on explotacióres of ?ess than 50 manzanas in size. ${ }^{16}$ on the other hand, about 90 per cent of the cotton, 92 per cent of the sugar, 80 per cent of the cattle, and 80 per cent of the coffee are produced on establishments containing more than 50 manzanas apiece. 17 Corn, rice, and beans re crown largely for internal consumption, whereas cotton, coffee, sugar, and cattle are export crops.

There are many factors reaponsible for the present petterns of landholding in sticerusus. The effects of some of these jo far back in histony, and others sre of more recent orizin. The oriuinal zrants of land made by the

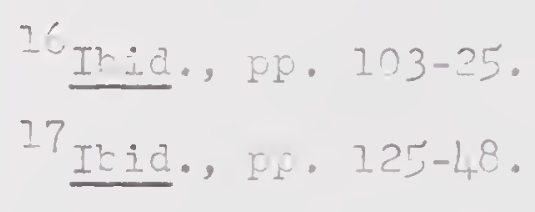


Iing of Spain to a favored fer established a custom that has not changed areatly in more than 400 years. It is unlikely that any of the original large grants have remained completely intact, or that any large grants are made as such todaj $k y$ the government; yet the same feeling that land is a symbol of importance to the individual and that it is a prize worth seeking persists todaj.

Political and military relationships are two important factors that have given a preferential position to some who today are large landowners. There is every indication that the National Guard is a vehicle of mobility in Iricaragua, operating much as the church or education does in other countries. In a study made by the International Bank, it was found that some of those who might have been able to invest in development projects were mone likely to invest their money outside of Micaragua because they felt that only those favored politically could succeed financially. 18

The years of internal strife have also affected land ownership and control. It would be difficult to document outright confiscation of land by the victors of the factional disputes, but there are some indications that such did occur. A few Micaraguan exiles living in

${ }^{18}$ International Bank, op. cit., p. 75. 
the sosta Ricar. Tovlanda have told me personally of their own losses due to just wch circumst nces.

Land taxation policies arc another factor in the concentration of Iandholding. The International Sank study found that only a small amount of Eovernment income came from property taxes, and little came from taxes on acricultural land.19 In the budget of 1966, approximately 12 por cent of Government income dij come from property taxes, kut there is no indication that any of this came from direct tarios on the land. 20 If the portion of the Asrarian Teform lemislation resarding lond taxation is enforced, it will undoubtedly bring chances in the landholdine practices of ricaragua.

Still another factor that has held back the development of medium-sized farms iz the lack of credit. The International zank report of 1952 made special mention of the "ineffective creait system, especially for the provicion of medium and long range agricultura? and industrial credits." A common practice is for a bujer to advance money and take a lien on the future crop. He then charces hioh interest on the loan he has made, and he also pays

\footnotetext{
79 Itid., p. 340.

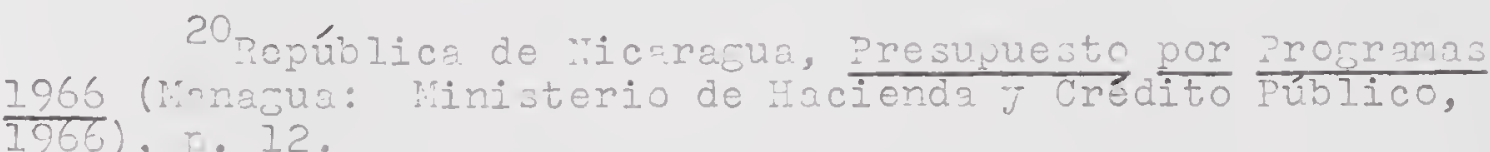
1966), I. 12. 


\section{6}

Iess than market price for the products at harvest time. This credit system is so fimmly entrenched that even international cooperative credit organizations have a hurd time breaking it. 21 Most of the crop bujers are also landowners.

The concentration of land ownership is even greater than the figures indicate in Tables 1 and 2 because man operators are renting land for the cropping season. The abundance of public lands, the low population density of the eastern half of the Republic, and the ease of rentin have all worked tojether so that there is not the great demand for land that is found in many other parts of the world toduj. As a result, the concentration of landholdings in the hands of a few owners has not been contested. is population pressure increases, the demand is lively to be sufficient to make some of the larger farms avilable for more intensive cultivation.

Sducation is related to size of farms both as cause and effect. I law was passed in 1917 that permitted the acquisition of puilic lands. The procedure vas simple, and it was directed at openino up new opportunities for acricultural laborers to acquire farm land of their oun. Tho Itr was surpended in 1952 because there were manj

21 stutements made durins irformal discussions with CUI:L/USAID officials in Nicaragua, "\#arch, 1966. 
cbuves, and it wa resulting in n increase of lutifundin.

-ncl- of educhtion wra cited sa the resson that the upri-

culturn I Isborers did rot tole iduntaje of the situntion. 22

ir acrorian reform law was promu? joted in Decerher,

Iǵl, with the following atipulution:

1. It wonld creute an irarian Institute, 3s a semi-autonomous acencit, reportine to the Prawident through the tinistry of neiculture with bro d responsilititied ower land set+l cment.

2. Innd scttlemert would involve public ?andu, lands purchased by the Arrarian Irstitute, and, there recescury for the redisation of a settzellent project, expropriated land with compensation determined bu a board of arhitration. In cases of exproprintion, the Contitution of "icuracua requires that immediate cash indemnity be made.

3. $\therefore$ tai on uricultural land is insroduced, the reverue from which irould be utilized for rowrams of land cettlement. This is a viunificant proposin, as previously land his not been apecifically tared in ricarşus.

4. Both directed and voluntary settlement are contemplated. in sarmor who has occupied public lund und cultivoted it for a period of one jear or more prior to the enactment of the law would be permitted to apply for title, thereby securing up to 50 hectares without ch je, and the balance, if he has cultivuted it adequately, at a price to be determined by a bocra of experts.

5. In the case cf directed settlement, ' and would be sold to the settlers, to be repaid

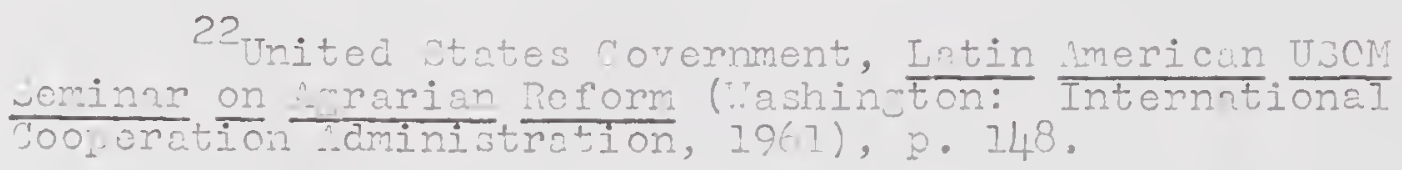


over a period of 15 to 20 years, with interest at a rate that is not to exceed 5 per cent. The amount to be repaid would be reduced by 5 per cent for each son born after the purchase contract is signed. Supervised agricultural credit would be introduced and adequate housing provided for each settler in a goverrment-directed project. 23

The agrarian reform measures were included in Decree 797, which was finally passed in April, 1963, with the proviso that it be administered by the newly fomed Agrarian Institute. 24 The main emphasis of the decree is on colonization of public lands, but it is too early to evaluate the results as jet.

Results of the Concentration of Land Ownership and Control

The low standards and levels of living found among a large proportion of the rural people are direct results of the concentration of landholdings. The International Bank found "cenerally low standards of health and education." A summary statement was made, which includes the following items: (1) it few people in Ticaragua enjoy a high income and a high level of living comparable to the best in turope or the Inited States; (2) the Iarse majority of the people

$$
\begin{aligned}
& 23 \text { Ibic., p. } 14^{R} . \\
& 24 \text { Feston, op. cit., mable I. }
\end{aligned}
$$


he rew incrmez and low levelo of liwing; (3) the boic diet is composed of corn, beins, plunt ins, and rice, but it is lacking in protein; (4) there is a Inck of wa fre drinking witer eren in the urhar weus; (5) the litcracy rate is mader an per cent; ( 4 ) there is a hijh incidence of miluria nad dysentery; ard (T) infunt mortality $\dot{i}$ hijw. 25

Sonsiderable progreas hau heen made since 1952, jet there is room for much imrovement. One of the striline characteristics of rural i.zcaracua is a lnck of pure water and soritary facilities. Beports of the 10,53 census indisate thit less than 1 per cent of the rural population

hire access to whtor sustems. ?h in actual cree which I personally observed crn be used ais an exmple of the extert of sanitany facilities. In ore rur l "illäe I counted 90 families; but the orly toilet facilitics of any kind were in the recently constructed school. These focilities were conuidered novity. This rillaoe is less than an hour's drive from the casital city of zanagus. The linistry of rublic aelth is ttempting to improre conditioni.

\footnotetext{
25 Interrutional 3nnt, op. cit., p. xxy.

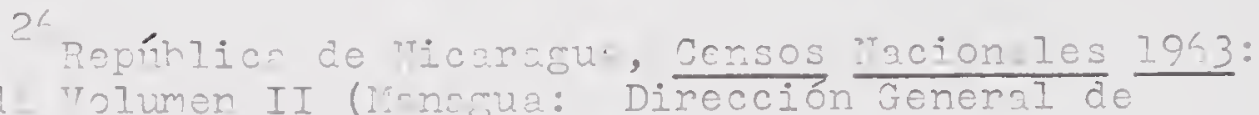

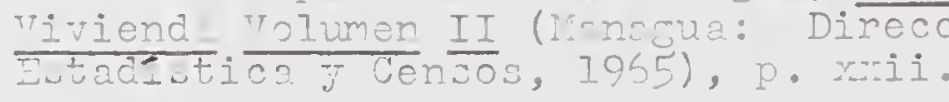


In the International Bank report of 1952, it was recommended that, because of the low levels that were encountered, both health and education be included in the plan for economic development. Some outstanding improvements can be noted in education in the subsequent period. Illiteracy decreased from 62.6 per cent in 1950 to 49.2 per cent in 1963. Yet, the rate of illiteracj in the rural areas was still at a high of 70.2 per cent, and only 18.0 per cent of the rural children were attending school. 27

Another result of concentration in the ownership and control of the land has been an exodus of rural laborers to the urban centers. Durand and Pelaez have calculated that the urban population is increasing at an annual rate of 5.9 per cent, while the rural population is increasing at an annual rate of only 1.9 per cent (even though the rural birth rate is higher than that of the urban centers). 28 The rural population accounted for 65.I of the total in 1950 and was estimated at only 57.I

27 República de Nicaragua, Censos Nacionales, 1963: Educación Volumen I (Managua: Direccion Teneral de Estadistic yCensós, 1965), p. xiii.

28 John D. Durand and Cesar A. Pelaez, "Patterns of

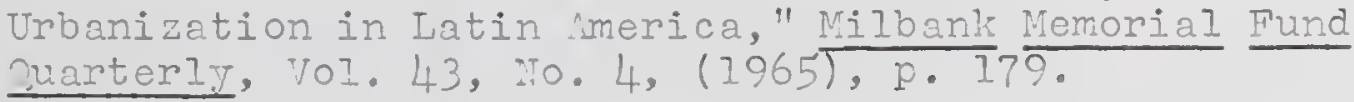


per cert in 1960.29 the sume time tht diffichlt conditions exist in the rural are.u, there ure many thinjo mulirj it etwier to go to the cities. These now alteraltives increase the likelihood of miuration.

The relationshif botweon larje landholdirjo, economic cosition, wd politicul power rould be hard to detemino timough exanination of official jovernment documenti. As onc travels uhroughout the Republic nc sals questioni, honeter, it is eridert that those who wre owrers of the langc t.olding: ilso ure promirent fiourcs in the ecoromic, politicil, and militury apheres. It is lirely that the pize to cconomic and wociul position may come from politiain und militury participution, iut zandhorainj serves to juiruntes a continuarce of this position.

\section{Tronds in Inndholdine}

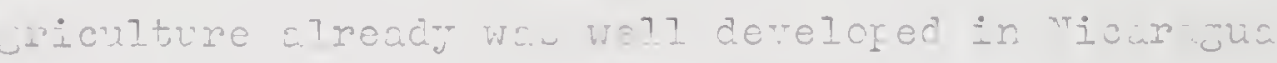

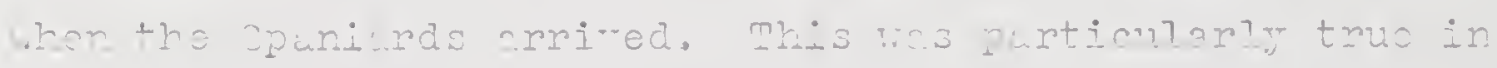
the we tern coustal wrew whare the ricarnno Iriland rosided. In controst with the romadic life of the nititus in the certrol ural castern reus, these Indirns had permanont? out iblished wilages und land bound ried. Land ownership wis onmmunc?, but the- did hure private orrorship of

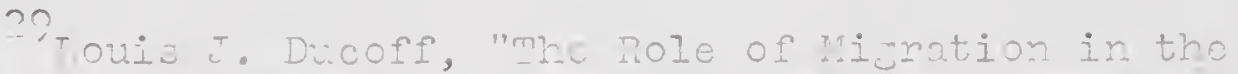

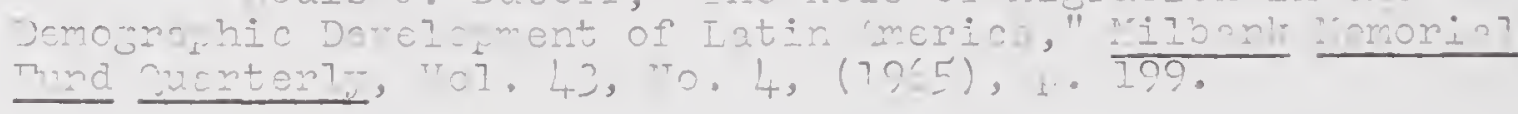


movable property. It was found that each area had a crude mappino system thit was used to holp define the limits of the lands pertaining to each village. There vas no scarcity of land, but the maps were used by the elders in the event of a dispute over boundaries. 30

cold was not abundent in Nicaracua, so the Ipaniards vere forced to use the land as the major source of wealth. Cultivation was begun almost immediately. The apaniards establiched pluntations of indioo and cacao for export, and the undertook the production of cotton, citrus, sugar cane, food crops, and cattle for internal consumption. The area of most intense cultivation was near what is now Rivas and cranada. In the Ieón area to the north, some attempts at faming also were made, but the soil and climate were not as favorable there. The central and eastern portions of the country vere not colonized during the early period. 31 Iandholding in ITicaragua followed the general pattern of all of the NTew Vorld that was under Spanish domination. Upon its discoverv, the whole territory was proclaimed as property of the ring. By persuasion or force much of the most desirable lands were taken over by

30 José D. Gomez, Historia de ricarasua (Manasua: \#1 Paŕs, 1889), p. 38. ${ }^{31}$ Ibid., pp. $51-56$. 
the conquistadores. The zpaniards of ill ranks were oujer to jet possession of larje tracts of land. For those of higher rank, direct sranta were mede hir the Ying; for those of lower rank, smaller Erants were שiven out by the leaders from lands that the King h-d desicnoted for this purpose. Small tracts of land were given in and near the areas designated a villages and town for buildinf homes and planting jardens; also some land was evailable or a rental basis from the lard urnts made to the communities. From the wery hejinning, spcoific land areas were desionated rs Indian communal holdings but in proctice they were not respected. Grsnts of land were rumerous in themsclves, Jet it was the eeneral practice for each recipient to extend his bounduries far beyond the limits of his legal possessions.

nother factor $3.1 s o$ influenced the size of holdings. $\therefore$ very small portion of the totel and liud been ? located ond, due to lack of precise description of property bounderie, there was much dispute as to how much belor ced t ench lard holder. A zenoral understanting devel ped that whichl occupation snd use wore z so important factor in the proof of yosseusion. Whis accourts for: Inrue Juintit: of lond thut las obtined neither from reyal oruntis ror by purchise.

The tendency to onrnt larje trects of lanc, the Iacl of aequnte description of koundarien, the Inck of 
adequate systems of recording the titles of ownership, the understanding that possession and use were important aspects of legal ownership, and the basic fact that land was abundant, all tended to make the large landed estate an ideal worth striving for. 32

The concentration of land in the hands of a few continued after the establishment of the Republic. The Constitution of 1838 respected private property and indicated no great concern over the tendency toward large holdings that had developed when Nicaragua was a Spanish colony. The Constitution of 1939 showed for the first time a concern for landholding. It stated that "property has a social function, and the obligations of the owner to society shall be determined by the state"; land taxation was first mentioned; and the government was charged with encouraging the preservation of medium-sized and small holdings and the division of latifundia. 33

Since 1939 the pressure for change in landholding has been increasing in Nicaragua. It was not until the Agricultural Survey of 1952 that an accurate appraisal of the size of holdings could be made. The data from this survey are summarized in Table 5. For comparative purposes,

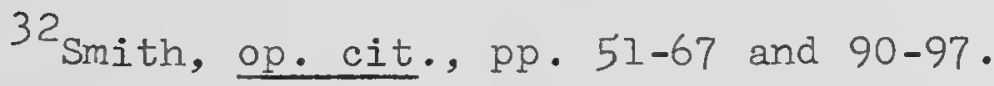

33 Blandon, op. cit., p. 19. 
TABIE 5

SIZE OF EXPLOTACIONES t-GROPECUARIOS

IN NICARAGUA, 1952

\section{Size of \\ Explotaciones \\ (manzanas)}

Per cent of

Explotaciones

(total)
Per cent of

total area

Under 5

19.9

0.8

\begin{tabular}{lcc}
\hline $5-9.9$ & 15.0 & 1.5 \\
$10-19.9$ & 16.7 & 3.3 \\
$20-49.9$ & 20.7 & 9.4 \\
\hline $5-49.9$ & 52.4 & 14.2 \\
\hline $50-99.9$ & 15.2 & 14.5 \\
$100-199.9$ & 7.3 & 13.5 \\
$200-499.9$ & 3.6 & 15.0 \\
$500-999.9$ & 0.9 & 9.2 \\
$1000-2499.9$ & 0.5 & 10.5 \\
\hline $50-2499.9$ & 27.5 & 62.7 \\
\hline 2500 and over & 0.2 & 22.3 \\
\hline Total & 100.00 & 100.00 \\
\hline
\end{tabular}

Source: Compiled and computed from data in Alfonso Blandon, Land Tenure in Nicaragua (Unpublished Master's Thesis, University of Florida, 1962). 
Table 6 is also presented to show the changes from 1952 to 1953. In this period of time, the number of holdings in ricaragua increased from 51,581 to 102,201, and the area involved increased from $3,388,789$ to $5,461,162$ manzaras. Of particular interest to this study is the fact that the trend shows a decrease in the relative number of medium-sized holdings as well as the relative area involved. It is in this catesory that the family-sized farm is most likely to be found.

\section{Summary and Conclusions}

The degree to which the ownership and control of the productive land is concentrated in the hands of a few individuals is the most important aspect of man-land relationships. This chapter on size of farms has described and analyzed the distribution of different sizes of agricultural and stock raisins establishments in iicaragua to discover to what desree this concentration exists.

Three main categories are used: small farms, those under 5 manzanas in size; medium-sized farms, from 5 to 49.9 manzanas; large farms, from 50 to $2,499.9$ manzanas; and latifundias, places of 2,500 manzanas and orer. Size as measured by area alone is not enough to determine ownership and control of the land but, when it is combined with land use, one obtains a good indication of how the capital, manasement, and labor are applied in the enterprises. 
TABLE 6

COMPARATIVE SIZE OF EXPLOTHCIONES hGROPECUhRIOS

IN NICARAGUA, 1952 AND 1963

Size of Explotaciones (manzanas)

$\frac{1952}{\text { Per cent of }}-\frac{1963}{\text { Per cent of }}$

19.9

0.8

35.4

1.5

52.4

14.2

42.8

13.2

$27 \cdot 5$

62.7

21.2

65.1

0.2

23.3

0.2

20.2

0.2

Over 2500

100.0

100.0

100.0

100.0

Source: Compiled and corputed from data in Alfonso Blandon, Land Tenure in Nicaragua (Unpublished Master's Thesis, University of Florida, 1962), and República de Nicaragua, Censos Nacionales 1963: Agropecuario. (Managua: Dirección General de Estadistica y Censos, 1966). 
The ideal social situation results when the famer and his family can provide all three elements.

In Nicaragua the ssricultural Census of 1963 presents adequate data on size of the asricultural estabiishments. The small-sized units account for 35.4 per cent of all establishments, but they include only 1.5 per cent of the acricultural land area of the Republic. The comparable data for the other cutegories are as follors: medium-sized eztaklishments, 42.8 per cent of the units and 13.2 per cent of the area; larse establishments, 21.2 per cent of units and 65.1 per cent of the area; latifundia, 0.2 per cent of units and 20.2 per cent of the area. These figures indicate that there is a high dejree of concentrution in the ounership and control of the agricultural land of ricaragua. Ther also indicate that a large number of cxtremelj small plots are present. This latifundia minifundia combination liliewise is characteristic of many other parts of the world.

The sizc of the acricultural-pastoral units also ranies considerably from ono to the other of the three natural seouraphic resions in Micaragua. The hions developed racific refion has a relatively more pronounced latifundiu-minifundia combination; the "iorth-Central negion has a rolatively hich proportion of medium-sized establishments; and the At rantic reaion has a sionificantly high proportion of large urits. 
When land-use is related to size of farms, a clearer picture of some of these man-land relationships emerges. Three main categories are used here to describe the use of Nicaragua's agricultural land. As the size of the establishments increases: the proportion of crop land decreases; that of pasture land increases; and that of forest land increases rapidly. As a specific example of this relationship of land use, forest and pasture land combined account for only 25 per cent of the area of small establishments, and 94 per cent of that in places of over 2,500 manzanas.

The concentration of landholding in Nicaragua is not due to any one factor. Certainly the Spanish heritage as a cultural pattern is an important starting point. Other factors are: the political upheavals since independence; the preferential position of a few individuals because of political and military association; the absence of an effective tax on land; the lack of agricultural credit for small farmers; misuse of public land grants; and the low levels of education among rural people. In recent times the growing concern over the inequalities in land ownership and control has brought about changes in the law. It is too early as yet to measure any significant changes in the size of farms as a result of these laws.

It is not possible to relate completely present social problems and the concentration in landholdings. Undoubtedly the low levels and standards of living in the 
rural areas do have a close relationship. Health and sanitation problems have been mentioned by many authors as an inder to this situation. In spite of sreat efforts of the government, illiteracy remains at a high of 70 per cent of those ten years of ase and over in the rumal areas. Because conditions have not improved in proportion to expectations, many rural people are migrating to the cities, thus compounding the problems already found in providing adequate urban facilities. An obvious result of the concentration of ownership and control of the land is the contrasting style of life for those in different social and economic positions.

The pattern of land ownership and control has changed little since the days when Iicaramua was a Spanish colony. There was slight opportunity for the pre-Columbian customs to prevail over the all-pervasive Spanish desire for land and the social power and prestige that went with it. Independence did not greatly change this cultural pattern, partly because land was abundant. Only in recent times have pressure for change been great enough and social contact with other areas of the world open enough to cause the rural population to realize that something should and could be done to bring about a more equitable distribution of ownership and control of the land in licarasua. 


\section{TI:IFTIRT $I^{Y T}$ \\ IND MTMUTD}

rer in thein relation th the rand love certrin ropuntir rights thet re recomized by snciet. These nifht, vary from mere customo, which one beclied ur by aifferent domees of safctions, to britter laws, which the coremment hos uthoritu to enforce vith mome severe mensines. Iand tenure deals vith trese lejal property niohts, on the relationship thet bird mar end tand together. I Two narects of these relationshins ane considered here: (I) the cenerel roture of cropertu nizhts to the lend ir "icsmacua, wh. (P) the rows in wich these mintu nre distributed amone the "icaraurano "ho depend ur on aniculturnl and pestonrl actimities scre livelircod.

Ind a property is a form of verith. To mary reople Inrdomership is possession that is cs importint $\therefore$ cold. Land ita funther " lue because it is capable of producing trose trings reeded daily by mar to sustain life. Itatus and prestice in society come from the

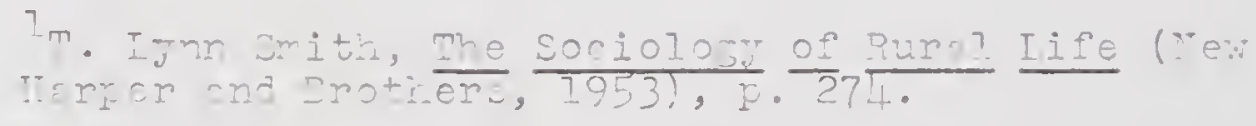


possession of scarce and valuable resources and, for this reason, the individual who possesses rights of ownership and control of land can influence the actions of others. As was pointed out in Chapter III, when the ownership and control of the land in a society are concentrated in the hands of a few people, equality in social relations is difficult if not impossible to achieve.

Iand as a form of wealth differs from other material objects in another important aspect: maintaininö phyzical possession of land as porsonal property represents a special problem because of its size. It is almost impossible to put land behind walls high enough or strong enough to prevent occupation by others. Squatter invasions hate plagued land owners throughout recent history and ure a major problem in some countries today. For thi reason, lesal rights to the land as defined in tenure relationships become extromely important. In the case of land, prysical possession does not always count for the proverbial "nino points of the law." $\therefore$ legal document is necessary to prove ownership. Thus, an accurate description of the extent of legal rights to the land becomes of rital significance in a stud of man's relationship to the land. 
Propert; Riclts ad Their Ierelopment

In primitire zocieties there is oreng rilielihood tho.t the right, now considered commensurrte with lecal wnerchip of land went with phisicnl occupation and use: that is, such rights essentiall vere held by the man who cultivated a rarticular tract wimply by rensor of ris occuption and "rse of it. ․s society becme more comple: and choice land was in preater demund, customs Joveloped in derline with problems of allocrtion and transfer of claims to particular tracts of land. Fradu3ly, oral and witten arreoments as to land richts and responsibilities were assembled and codified. In the course of time, the emphasis has atifted from mere occuprtion and rise of the lend to the possession of documents recomized by society as simifrino some lind of a leçal title to the Iena. The history of property right: to the land in Ticnrous is much like that of the other Jronish colonies. Iufore the coninj of the Sreniards, the pressure of population $u_{\text {on }}$ the lanc was not ireat, nnd since the nitive Indiens hod not chiered a written lenuege thero was no lecal documentation to certifu the ridhts of an indiridual to the 7and. Acoordin to the customs and terta? upreonento with the tribe and amore the tribes, 7 nd wo nIlocuter ccoording to reca. aimple mul are developed to 
define the limits of property rights as to area, but no further codification of custom was observed.?

The present-day tenure arrangements in Nicaragua can be traced to the Spanish colonizers, but they were not necessarily found in Spain. Land tenure provisions in Spain had many recognized deficiencies, and these were wisely corrected in the laws that were used in the colonies. From the beginning, the land was claimed for the Crown. This was one of the first "rituals" performed by the conquistadores. The King began to dispose of the land in liberal quantities, but not without reason or an idea of its value. Rather specific stipulations were made as to how the amount should vary in accordance with the rank and position of the recipient. ${ }^{3}$

During the first part of the colonial period, there were three ways in which an individual could acquire property rights to the land: (I) by grants given directly by the King; (2) by assignment from the leaders of expeditions whom the King had commissioned to distribute rights to tracts of land to their followers; and (3) by allotments also made by the leader of an expedition or the council of a new settlement, of building lots. It

2José D. Gamez, Historia de Nicaragua (Managua: El País, 1889), pp. 37-38.

3. Lynn Smith, Colombia: Social structure and Process of Development (Gainesville: University of Florida Press, 1967), pp. 90-91. 
wa l ter decreed that full rights to the land, equivalent to fee simple were to be fiven after four Jasrs of residenc:. In addition, some lands were üiven to the new settlements as commun I property, nomely eidine adjacent to the town plots for use as common pasture and propins to be used or rented and with the proceeds to be used for community purposes. 4

Innd iss abundret und the grants were libernl, wet there was olrys a deaire for more land. Py 1597 the disEutes orer land possession were so numerous that a review Of all claims wes decreed.

The putication of the Inw of the Indies in 7680 ‥s nother important derelopment. The tarious remit:ticki that had hoon a pant of coloni=l dolicy had keer codified nd tere rublished at this time. wh-ae 7 iw

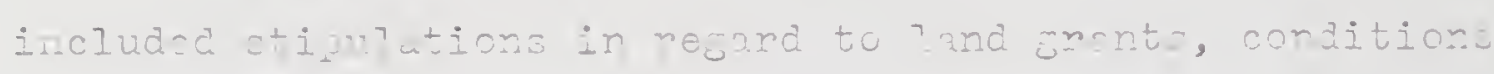
recsaceny for defirite title, time limiti nn lond use ond construction of a die linj crefererce ir 1 . nd srontz, mothods of confimmotior of land titles, Irdian minhte to the I-na, locution of l nas fer lirewtocle in polotion to

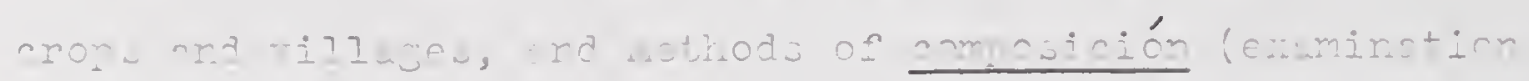

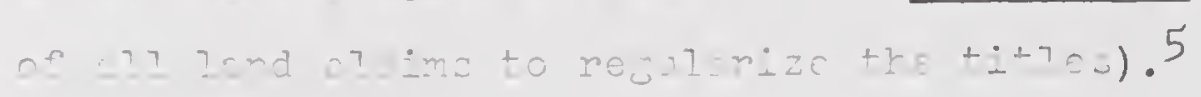

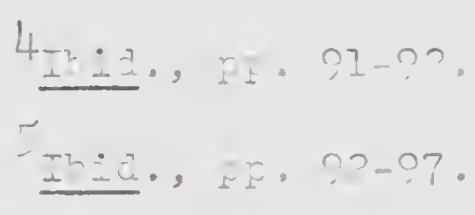


In spite of thiu, abuses were comron, and the Mine was forced to take corrective measures. However, because of local pressures as woll as the distance from Sfain, many of the decrees were rever carried out. Some of the problems that developed during this period remain today in tenure rolationships, and include: (I) the lack of a clear definition of the grants made by the rine to individuals; (2) a general tendency for the recipient to extend the boundaries of the grant beyond any reasonable limits, and (3) the lack of an adequate method of reaistering land transactions and preserving the records. 6

Moday, property rights to the land in "icaragua are defined in the Constitution. As was true during the long colonial period, these rights also have been essentially equivalent to fee simple since the adoption of the Constitution of 1838 . In essence, the state retains only the right of eminent domain, those to the subsoil, and that of taxation. In addition to the rights of ownership, the social obligations of property ownership are also prescribed. The articles of the constitution of 1950 (which is now in force) pertaining to property rights are as follows:

$\frac{\text { Article }}{\text { may be deprived of his property except by }}$

6 Alfonso Blandon, Land Tenure in Nicarasua. Master's thesis (Gainesville: Unitersity of Florida, 1962), p. 14. 
judicial judjement, f cenernl tax, or for fublic use nd social interest accordins to law and upon prion pajment in cash of just compensation. In the event of national war, or internal liaturbance, or public calamity, the competent authonities may use prirate property to the extent required by public wood, learing intact the rights to subsequent compens-tion.

Anticle 65. Property, by rintue of its social furction, imposes oblifations. The law shall atemine their amount, nature, and extent.

Anticle $6^{\prime}$. The risht of r roperty, as far is its e Fencise is concemed, is surject to the limitaticns imposed by the maintenance ind promress of socizil order. mhe lav may impose obliuttions or easement. of fublic use -nd maj resur ite questions of rent.

article 67. Propert;, resaralezs of who masetic orrix, is covemed exc?usire

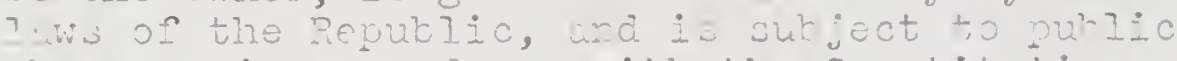
ciurjes, in ccordance witl. tle jonstitution and tive I-ns.

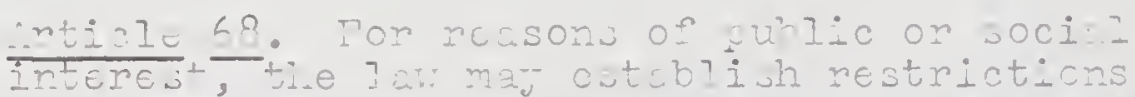
or pnsizitions or the acquisition uni trunsfor of centuin linda of Froforty because of it nuture, conition, cr locition in tie t=rñtor.

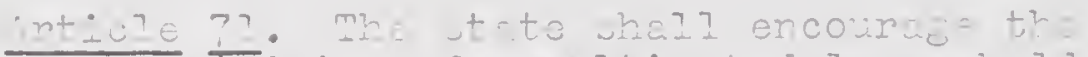

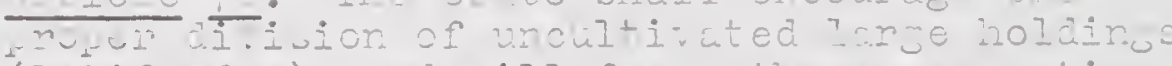

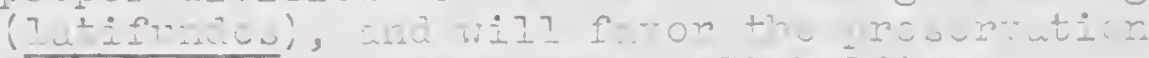

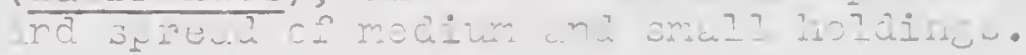

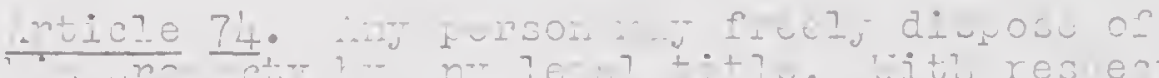

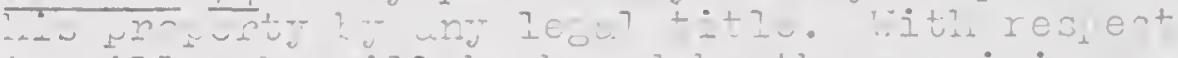

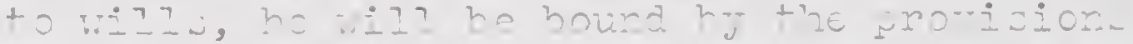
of ? ni nol-tinj to the naxing-? nonticr. nn -77oricnce for injort.

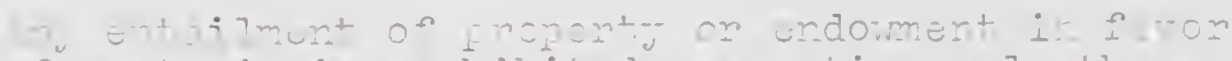

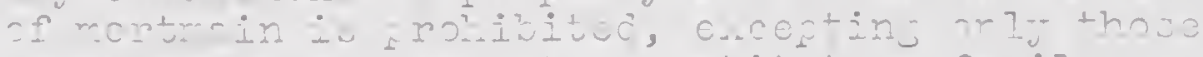

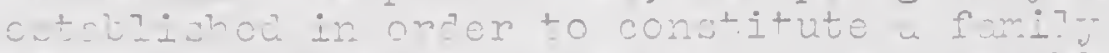

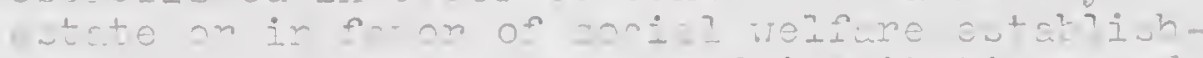
mentz snd fffoill center. of inctitutiors and $\cos ^{7} \operatorname{tine}$. 
Article 75. The fomily estate (patrimonio fmiliar is established on the basis that it Shall be inalienable, unattachable, and exempt from every public chirse. This principle shall be reaulated bJ law.

irticle 24?. Lneds, woods, waters, and in generil a.I property of public use belong to the state, except for leşily acquired rishts. The Law shall prescribe the conditions for their use by the state, or for granting them to individuals, in fee or by another title.

Article 2li2. The riches of the subsoil belons to the state. Their exploitation by indiriduals may be wuthorized only on the basis of farticipation $\mathrm{kg}$ the state in the profits. Ircepted from this provision are stones for buildins or ornamental purposes, pozzuolana, scnd, slate, claj, lime, and other substances jenerally used in construction. 7

il thouth the essertial elements of property rights to the land in ricaragua have not changed from those specified in the earl: constitutions, there have been some development and clarificution. The right of disposition (presently in frticle 74) was first stated in the constitution of 1893 , as was the protection acainst entailmert. Statements much 1 ike those in irticles 65, 66, and 71 were first included in the constitutior of 1939, and it is these which provide the lezal basis for gcrarian reform.8 frticle 63 was amerded by the "intional congress in 1966 to read "for reasons of firrarian Refom, when

7 Pnn merican Inion, constitution of the Republic of licaragur - 1950 (Iashington: Organi 2 ition of imericar States, (966), pp. 8, 9, and 38 .

Blandon, op. cit., pp. 18-19\% 
79

Therlti:t+en 2-tifundi we considered, the we ment c.r bc meie in soremment bonds, the durtion, interest and ctuer conditions of which ritil bo fired k. law.

zomo of the more imprtant proporto riukt to the I and that are avilin? Ie to the indiwidu I wre the fc? or in: (I) the exclusire right of hysical possusiar in?

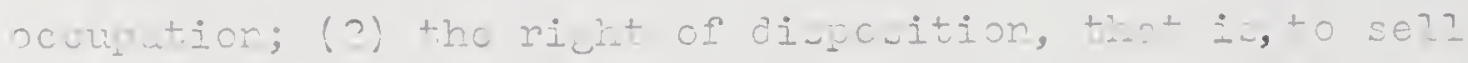

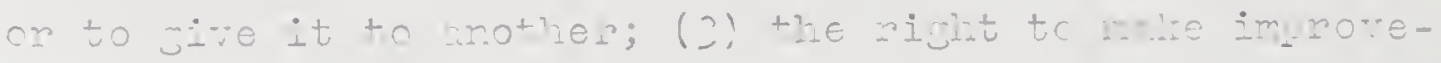

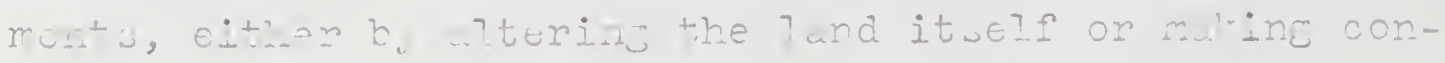

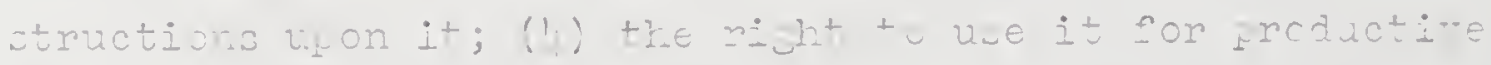
nmposes, i.e. to decidu wht to preduce, itun to rrochos,

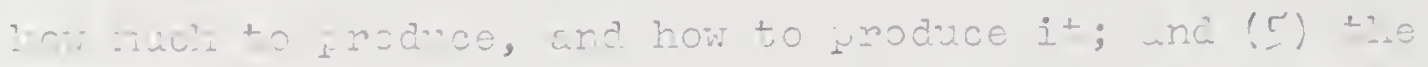

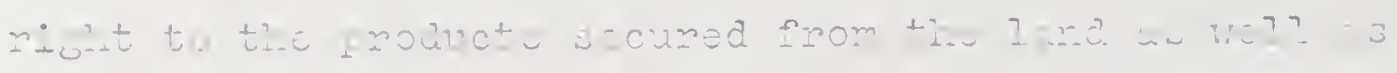

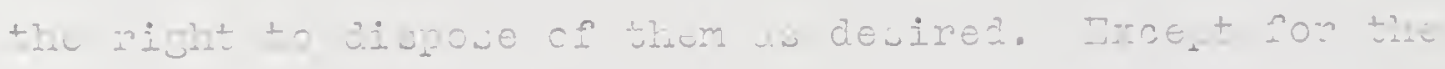
nestnictichis wpecifi. in the annatitutiun, these n

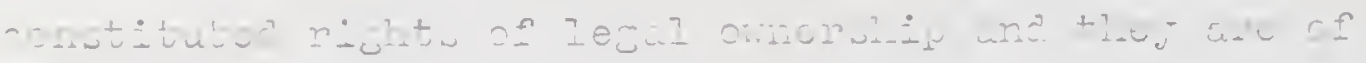

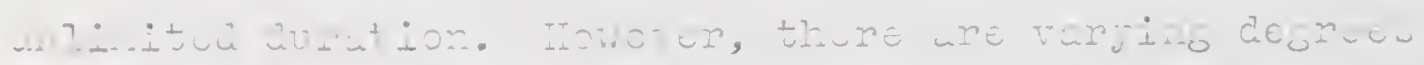

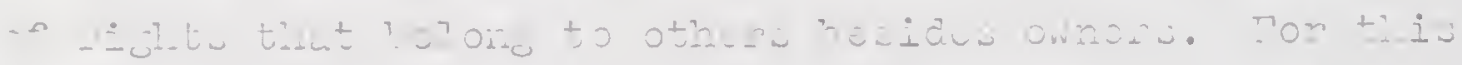

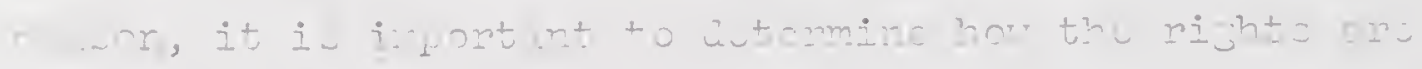

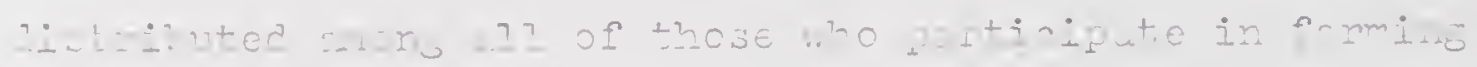

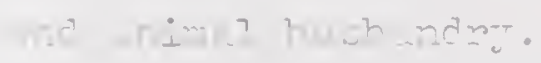

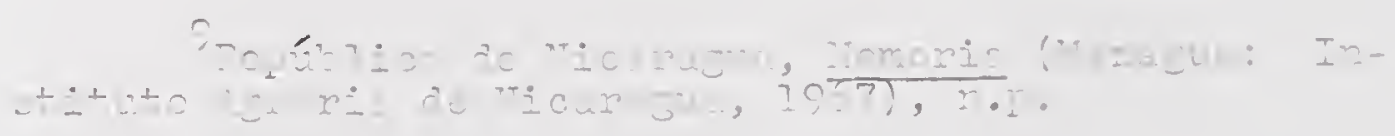




\section{miso Eenure status of \\ Ticarauman Porm Personne?}

The accord furdamental part of the study of land terure imolves i determination of the distribution of the sundle of property richts to the land amone the agricultural rersonnel. In thiz anclysis one must deal specifically with the two lange cutejories, namely farm ojerutons und form laborers into which that personnel is divided.

The first wef necessarily is the determinution of the ufproximate number of families dependent on agriculture und stocl: ruising. After this has been accomplished, the second step is to estimate the absolute and relatire importince of furm operators and farm laborens respectiveIy. is a final step, the ubsolute and relative importance of some of the specific categories of farm operators and fam laworers should be calculated. 10

It must be emphasiced again that an explotación ajpopecuario is not synonymous with what is cenerally understood as a farm. The major difference is that the cutesory of explotaciones includes not only all of the tracts of land that properly may be classified as fams, but also very larje numbers of small subsistence tracts used bu farm laborers.

${ }^{20}$ Smith, Colomtia, p. 108. 


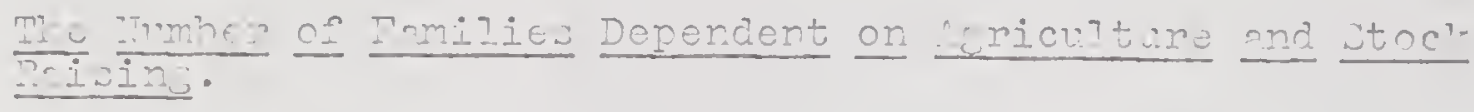
sepanite sets of compilations lead us to the con-

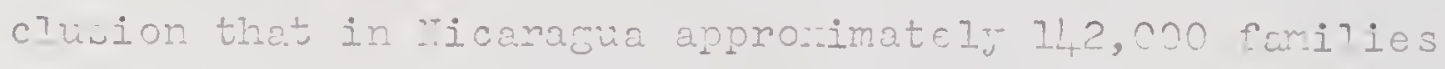
re depondent on acriculture and stocl raising for a liwelihood. The manner of maline these estimates is set forth in the following paragraphe.

Tirst, 124,560 reads of families hive been classed a being economicill sctive in urriculture and stock risinj.11 Thia includes sore femilies that live in rrban conters 03 well as those residinj in rural wreas. "crrewor, it does not includo any femilies that are herded by ferwors who are not economically active, and for this rea.on $\dot{\mathrm{i} s}$ an understutement.

accond, the 1963 cersus enumerated a total of

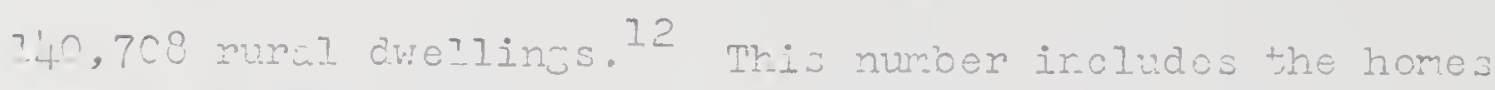
of rur. I forlies that are not ensaged in farmino but it does rot include those of urricultural perzonnel tho live in unban centers. Theie two eroups are approximately equil in nimber so thut the original figure is close to the uctuil number of farilies of fam personnel.

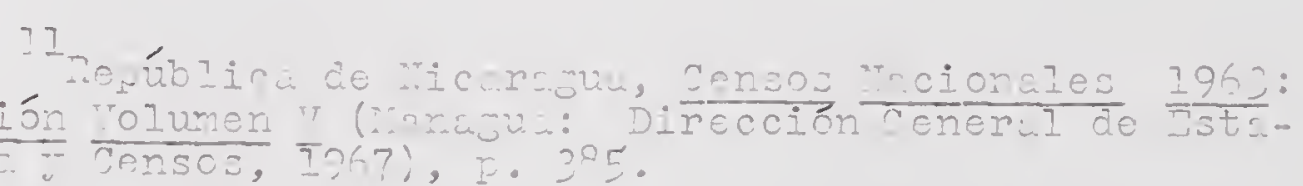

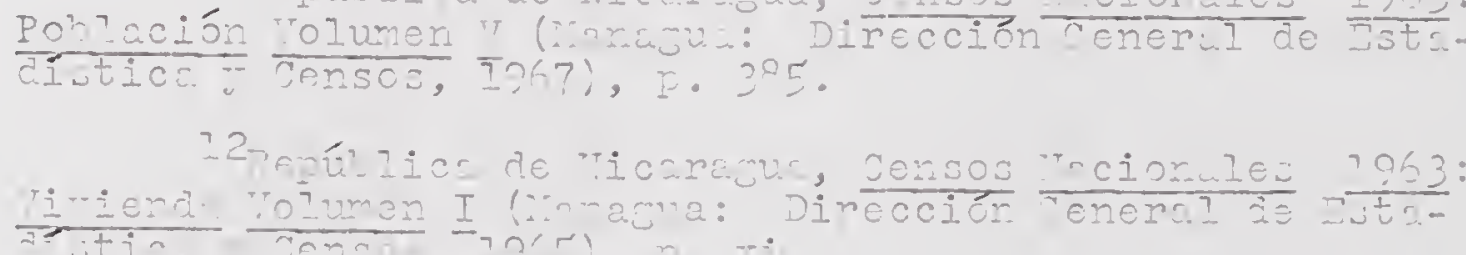


Third, a slightlj different wproach jivts 142,032 farm families. Mhis result is obtuined ky dividine tre total nural pcpulation $(208,296)$ by the mean size of rural families $(\{.4) .13$ igain, the rural families not enjaged in acriculture and the urban fumilies who live by fuming wre not taken into uccount, but they ure approuimate? equa in number.

Toun, 270,637 people wre reported as beinz economicunIy wetive in forring. If this number is divided by the mean number of persons pen family who are economically active (1.99), the computation jives an estimated 140,974 farm fomilies. 14 mhese fijures include both rural and urbur persons.

Thus, although the figures by no means should be considered exact, there is rery good reason fon taline 142, CoO as a fain approximation of the actual number of asricultural families in Micaracua.

Farm coerators.

The determination of the numbers and proportions of ricurajua's families tho belonj in the categories of

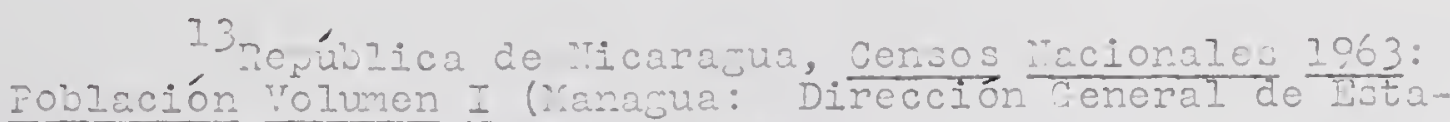
dIstica censos, I964), D. ani.

ILrepúbica de ticarasua, Censos tacionales 1963: Pobleción Tolumen III (Ianacua: 


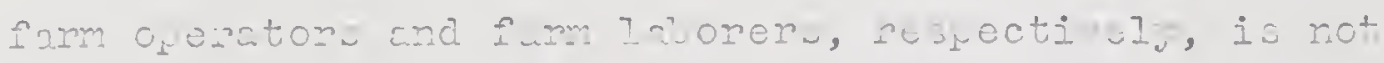

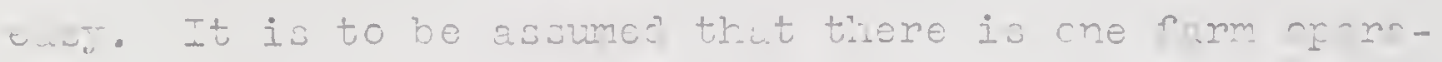

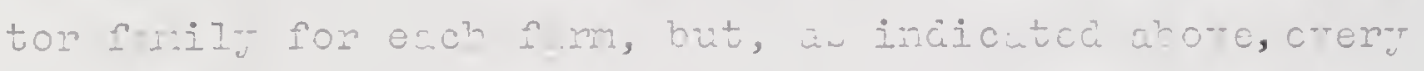

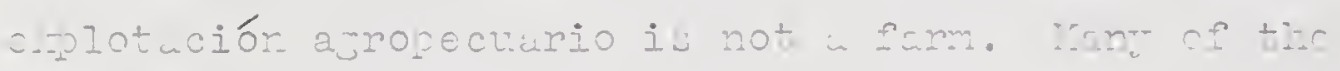
mull glots are merel- quina (amall country estrtes of neople who ror:- in the cityl and many others cre trocts iren in use to farm luhorers as partial purnent for their .orli on lanje fams. Tor this reison, il of the exilotacioncs contining less thin I maxianin, ore-half of those involving from I to 4.? manzanis, and one-third of thouc of from 5 to 9.9 merzinis are ezcluded from the catejory of fums. If these atractions are made, 79,923 explotaciones uropeciantos re left and most near? meet tire requitites fon alssificution us farms. ( vee male 7.) nnother aprroach car be used also. The cersus erumenations account for 140,977 furmers, stoclmrisers,

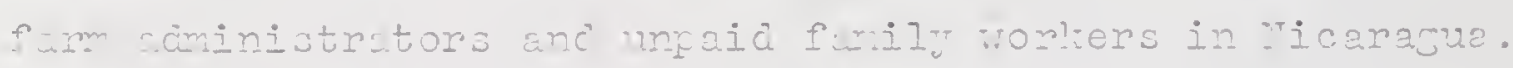
(see Trhze 8.) Soncidening the there rese 7.88 persons

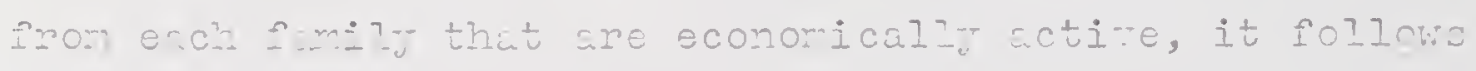
thut there re 79,243 familiej of fim coerators. Lotiz of tinese wrosches zi:-e approximetery the

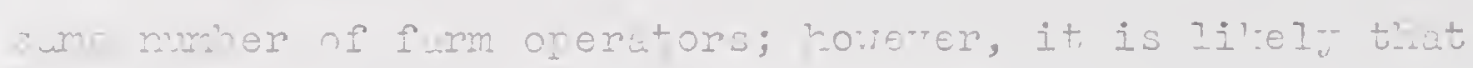
the fijunce urri ed at throngh both uppouches une too hili. There a man explotacionca of whore in munanas

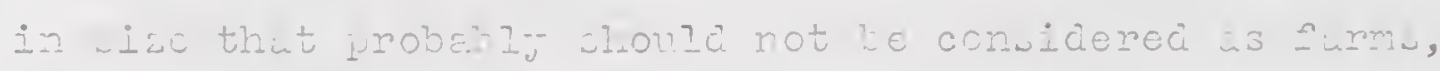

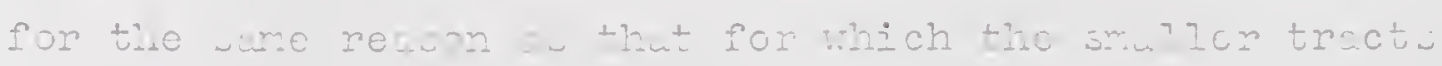


EXPLOTACIONES AGROPECUARIOS ACCORDING TO. SIZE IN NICARAGUA, 1963

\begin{tabular}{lrc}
\hline & \multicolumn{2}{c}{ Explotaciones } \\
\cline { 2 - 3 } (in Nanzanas) & Number & Per Cent \\
\hline Total & 102,201 & 100.0 \\
Less than 1 & 2,258 & 2.2 \\
$1-4.9$ & 33,948 & 33.2 \\
$5-9.9$ & 15,730 & 15.4 \\
$10-19.9$ & 13,273 & 13.0 \\
$20-49.9$ & 14,703 & 14.4 \\
$50-99.9$ & 10,949 & 10.7 \\
$100-199.9$ & 6,291 & 6.1 \\
$200-499.9$ & 3,551 & 3.5 \\
$500-999.9$ & 920 & 0.9 \\
$1000-2499.9$ & 405 & 0.4 \\
2500 and over & 170 & 0.2 \\
\hline
\end{tabular}

Source: Compiled and computed from data in República de Nicaragua, Censos. Nacionales, 1963: Agropecuario (Managua: Dirección General de Estadistica y Censos, 1966), p. xiv. 


\section{TABLF 8}

POPULATION ECONOMICALLY ACTIVE IN AGRICULTURE AND STCCK RLISING ACCORDING TO CCCURATICMAL LEVEL $I_{1}^{N T} T_{I} I A R \wedge G U A, 1963$

Cultivators, stock raisers and

administrators of explota-

ciones asropecuarios

91,543

Cultivators and stock raisers

91,049

Administrators

Farm laborers and gardeners

185,385

Laborers

125,287

Unpaid family workers

57,434

Operators of agricultural machines

1,651

Gardeners and caretakers

Other laborers

Total population economically active in agriculture and stock raising

تource: Compiled and computed from data in República de Ticaracua, Censos Macionales, 1963: Población Volumen I (Managua: Dirección Ceneral de Estadística y censos, 1967), p. 131. 
were previously excluded. Their exclusion would lower the first calculation. It is also likely that not all of the unpaid family labor should be considered as part of the family of farm operators. If so, this would lower the second figure. For these reasons, the number of farm operator families in Nicaragua is calculated to be approximately 72,000 , or 49 per cent of all agricultural families in Nicaragua.

In Nicaragua, there are a number of common terms used to denote the various types of farm operators. The meanings vary slightly from place to place and from common to legal usage, but they are generally understood by all. These terms are used here to describe the specific categories of operators.

A propietario is one who has legal title to land and is operating it as a farm. He enjoys all of the rights provided by the Constitution; in fact many of its restrictive aspects are not generally enforced.

An arrendatario is a farm operator who secures the use of land for a stated time and usually for a set purpose, through payment of a fee to the owner, usually in cash and in advance. At the present time a large amount of land is being rented in the Pacific region for use in cotton production; and the annual rent is around 300 córdovas (approximately \$42) per manzana. The duration of the rights to the land is restricted to the cropping 
season, the right of capital improvement is withheld, the decision-making rights are restricted to a specific crop, and no transferral rights are granted. This arrangement is made verbally where small amounts of land are in question, and by written contract in large transactions. Usually the arrendatario operates on borrowed capital; therefore, the credit agencies insist on a written lease. Commercial crop land is usually rented on an annual basis with an option to continue for another year. Land for other crops is rented on a long-term basis and more of the rights are transferred to the renter for the duration of the contract.

A comunero (also known as an ejiditario) is actually a renter and is a farm operator who uses municipio lands. He pays an annual rental fee and can sell his rights to another by a carta de venta (a written bill of sale that has been notarized). The cumunero does have the essential right of decision-making in all matters of farm operation but the duration of his tenure is insecure.

A usufructario is generally understood to be a farm operator who is allowed to occupy and use land that is owned by another. No legal contract is involved and the duration of these rights is always in question. This has been a stable arrangement in the past, but recent agrarian unrest has fostered a desire for legal recognition on the part of the usufructario. 
A poseador is a squatter, i.e., a farm operator who occupies and uses land that has no other legal owner. This is the case of those who live on national lands (tierras baldías). All of the rights are in question, but there is a recognized procedure for getting a provisional title (título provisorio) and later a legal title. This was common in the North-Central and Atlantic regions, although the Agrarian Reform laws have recently changed the procedures for securing titles.

An ocupante (also called precarista and paracaidista), also a squatter, is a farm operator who occupies without permission land that legally belongs to another. There are no recognized rights in this situation in Nicaragua, and the number of forced evictions and legal actions to get such interlopers off the land is increasing daily.

These common designations do not coincide with the tenure categories used in the agricultural portion of the Census of 1963, for the latter are based on land classifications and not on an analysis of the agricultural population. The categories of land as defined in the Census are as follows:

1. Owner-operated (propias): Farms with legal title that are operated by the owner.

2. Usufruct (usufruto): Lands not owned by the operator but from which the operator has rights to crops and benefits. 
3. Lands rented from a municipio (ejidos): Lands belonging to a county-like municipio, to which the operator has cultivation rights and pays an annual fee.

4. Lands rented from private owners (arrendadas): Lands rented for cash, for an amount of the crop, for services rendered, for a share of the crop or for any other form of payment.

5. Lands occupied without title (ocupadas sin título): Public or private lands that the operator cultivates without any legal title.

6. Other forms (otras formas de tenencia): Lands occupied by colonos, or any other form of tenancy not mentioned above. 15

The number of families in each of the categories of farm operators as calculated from the data available in Tables 7 and 8 presented previously as well as Table 9 are as follows: propietarios, 32,500; arrendatarios, 4,000; comuneros, 7,500; usufructarios, 5,000; poseadores y ocupantes, 19,000; and mixed operation, 400. When all of these are added together, the total is 72,000 operators which is the same as the total number of families of farm operators presented previously. These calculations are made with the necessary adjustments to eliminate those explotaciones agropecuarios that cannot be classified as farms.

15República de Nicaragua, Censos Nacionales 1963: Agropecuario, p. xvii. 


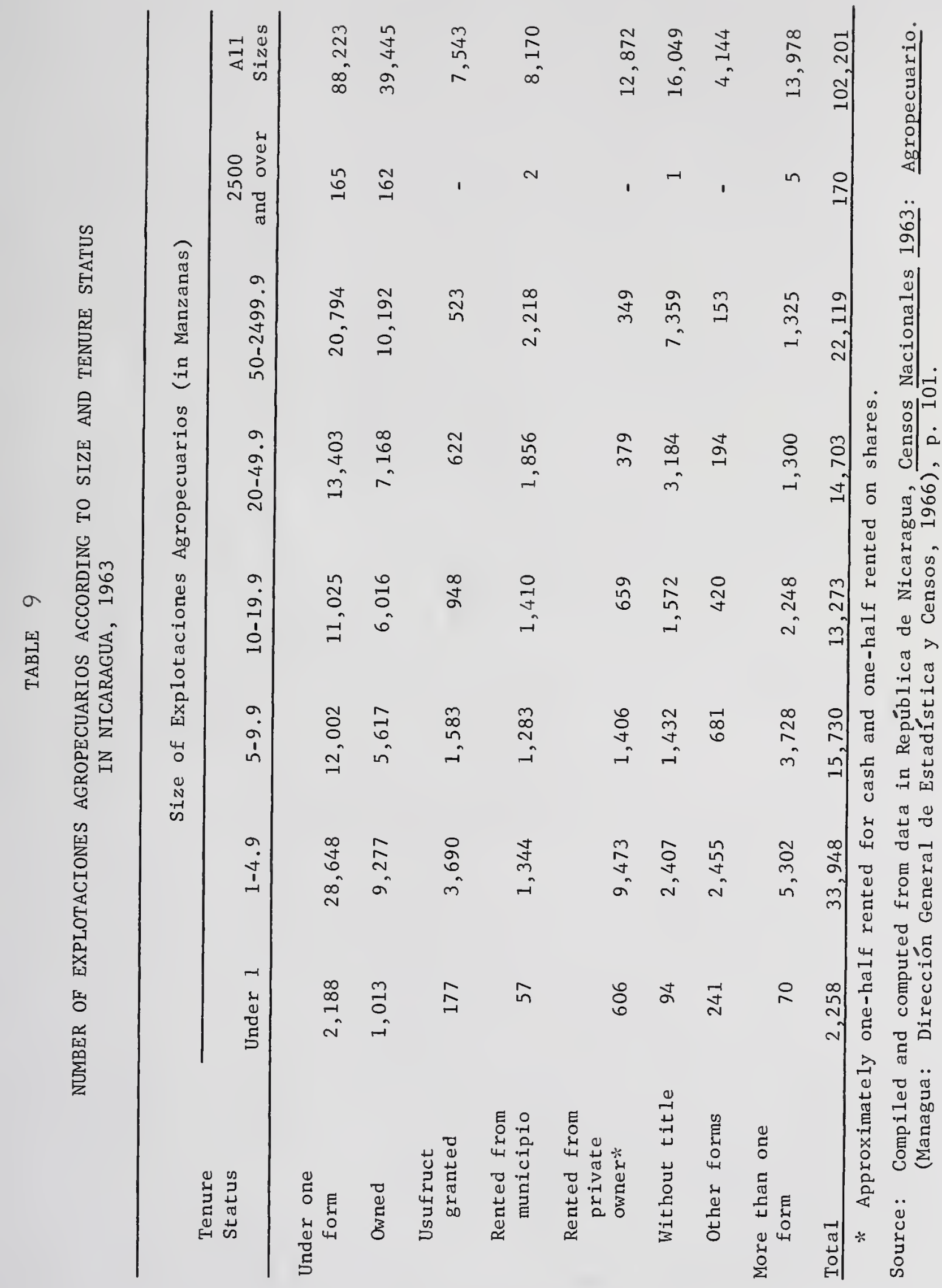


Farm Laborers.

The remaining Nicaraguan farm personnel must be classified as Iaborers because they do not exercise the managerial functions in the production process. The number of families headed by farm laborers is estimated by subtracting the families of farm operators from all families of farm personnel, and the figure secured is 70,000 families.

The above calculations can be checked by using the information of Table 8. The number of farm laborers $(125,287)$ is divided by the mean number of persons per family that are economically active (1.88). This gives a total of 68,059 such families. However, if some of the unpaid family workers are considered in this category then the number is increased thus approaching the 70,000 as previously calculated. All of this means that almost onehalf of the families dependent on agriculture and stock raising in Nicaragua do not have the property rights to the land which are necessary to be classified as farm operators. 16

16The Food and Agricultural Organization of the United Nations has combined all of the data of the 1963 Census that relate to land tenure and size of holdings. This collation, which shows a farm population of 283,000, indicates that 79.8 per cent of the rural families are either completely without land, have insufficient land to furnish a minimum income, or have few if any legal rights to the land they are now using. Food and Agricultural Organization, Nicaragua: Características 
Nicaraguan farm laborers fall into several categories, each of which is denoted in a common parlance by a specific term. First in these categories are the peones or jornaleros, who work by the hour, by the day, or by the

Generales de la Utilización y Distribución de la Tierra (A preliminary report prepared by the office of the Food and Agricultural Organization of the United Nations in Mexicol, p. 59.

In an earlier attempt to separate agricultural laborers from farm operators, Maturana compiled the occupational data from the 1950 Census and later data on the size of agricultural holdings. He found a farm population of 206,800 in which the proportion of agricultural laborers is greater than the proportion of farm operators and their families.

Still another attempt has been made to separate the two categories with size of farm as the criterion. Each family was assumed to have five members, resulting in a total of 133,300 farm families. Of these, 10.7 per cent were self-employed operators of family-sized farms, and 28.5 per cent were self employed on farms of subfamily size. The remaining 46.3 per cent were wage-earning families. Maturana has noted that the underemployment of those who live on the subfamily-sized farm means that most of them should be classified as wage earners instead of self employed. If this classification is made, then 74.8 per cent should be categorized as farm laborers and only 25.2 per cent of the heads of farm families as operators. Sergio Maturana, "Land Tenure" in Egbert de Vries (ed.), Social Research and Rural Life in Central America, Mexico

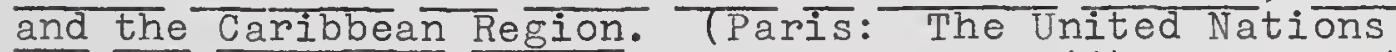
Educational and Scientific Commission, 1966), pp. 73-94.

In an earlier study, Schulman calculated that the economically active agricultural population of Nicaragua was divided into 19.3 per cent farm operators and 80.7 per cent farm laborers. Sam Schulman, A Sociological Analysis of Land Tenure Patterns in Latin America. Doctoral dissertation (Gainesville: University of Florida, 1954), p. 294. 
job. They are told what to do and how to do it by the farm operator or his representative. The only right they have is to receive an agreed upon wage and, until recent minimum wage legislation, even this was uncertain.

Aparceros are those who are paid a share of the crop for their labors instead of a cash wage. These are often classified as renter-operators instead of laborers, but close examination reveals that they do not exercise the right of decision-making. The managerial functions of combining land, labor, and capital in order to carry on one or more farm enterprises are exercised by the operators for whom they work, but not by the aparceros themselves.

The colonos are agricultural laborers who are allowed the use of small plots of ground on large haciendas or plantations as partial payment for their labor. They too are often classified as operators, but they lack all of the essential rights of an operator. The bulk of their time and energy is spent working under supervision on the hacienda or plantation and even the right of decision-making on their small plot is limited. No major improvements can be made without express approval from the landowner. By living on the hacienda or plantation, the colono even forfeits some of his rights as a free laborer to move about and look for better work. 
Arrimados are much like colonos in that they are given some kind of housing and perhaps a plot of ground while they are working in the area. Their stay is of short duration, and they can be classified as migratory laborers.

The approximate numbers in the specific categories of families headed by farm laborers are as follows: peones and jornaleros, 58,000; aparceros, 7,000; colonos, 3,000; and arrimados, 2,000. Included in these numbers were those who are listed in the census as operators of extremely small plots as well as the specific laborer categories. (See Tables 7 and 8. )

It should be mentioned here that all of these approximations are lower than the exact figures but were adjusted to conform with the total number of families headed by agricultural laborers $(70,000)$ as calculated earlier. This suggests that there are probably from two to three thousand families that could be shifted from the operator to the laborer category. At any rate the number of families headed by farm laborers is approximately equal to that number headed by farm operators.

Regional Variations in Tenure Status

The census data make possible an examination of the variations in the tenure status of the farm personnel from region to region. Tables 10 and 11 present the number of 


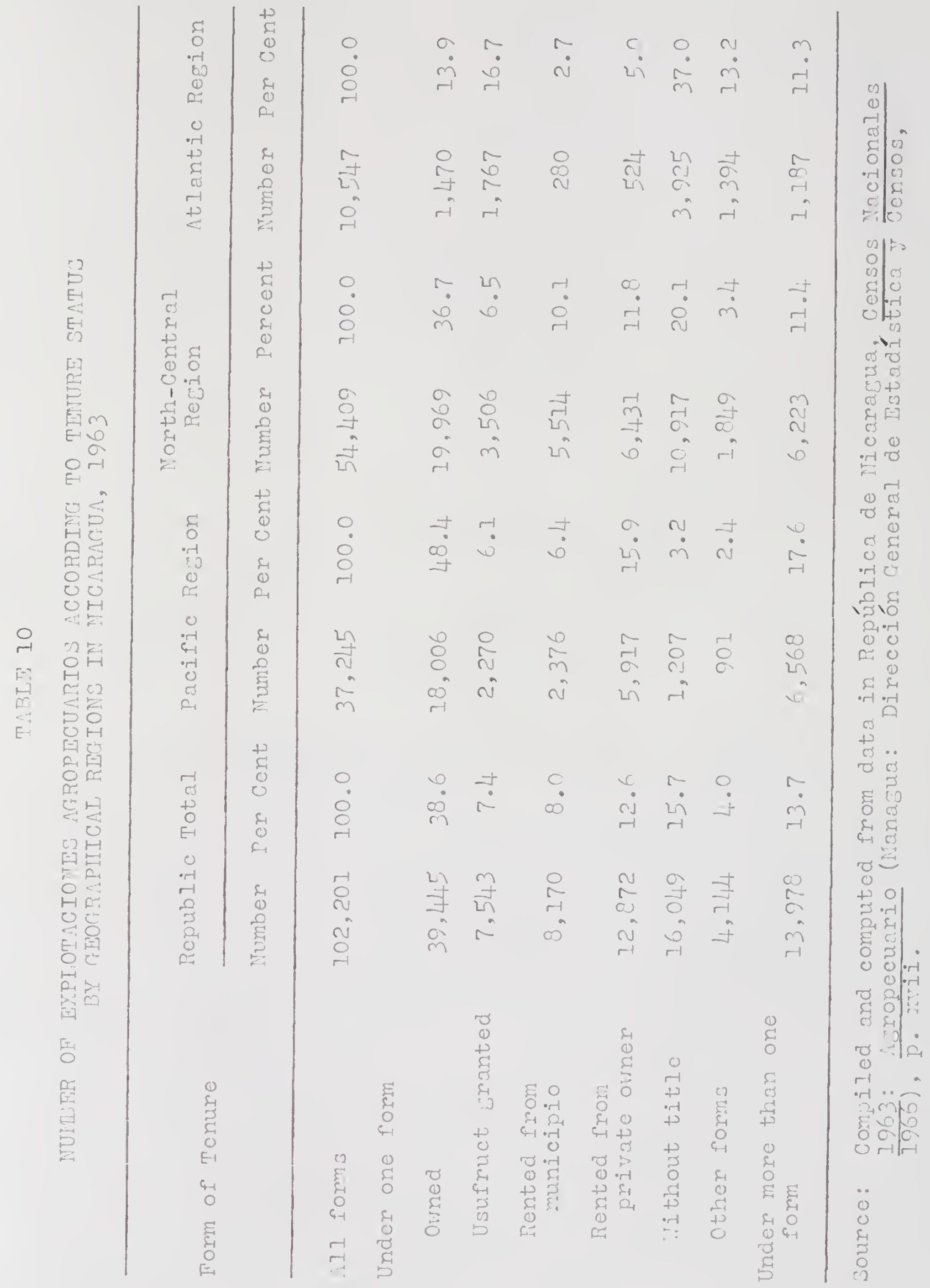




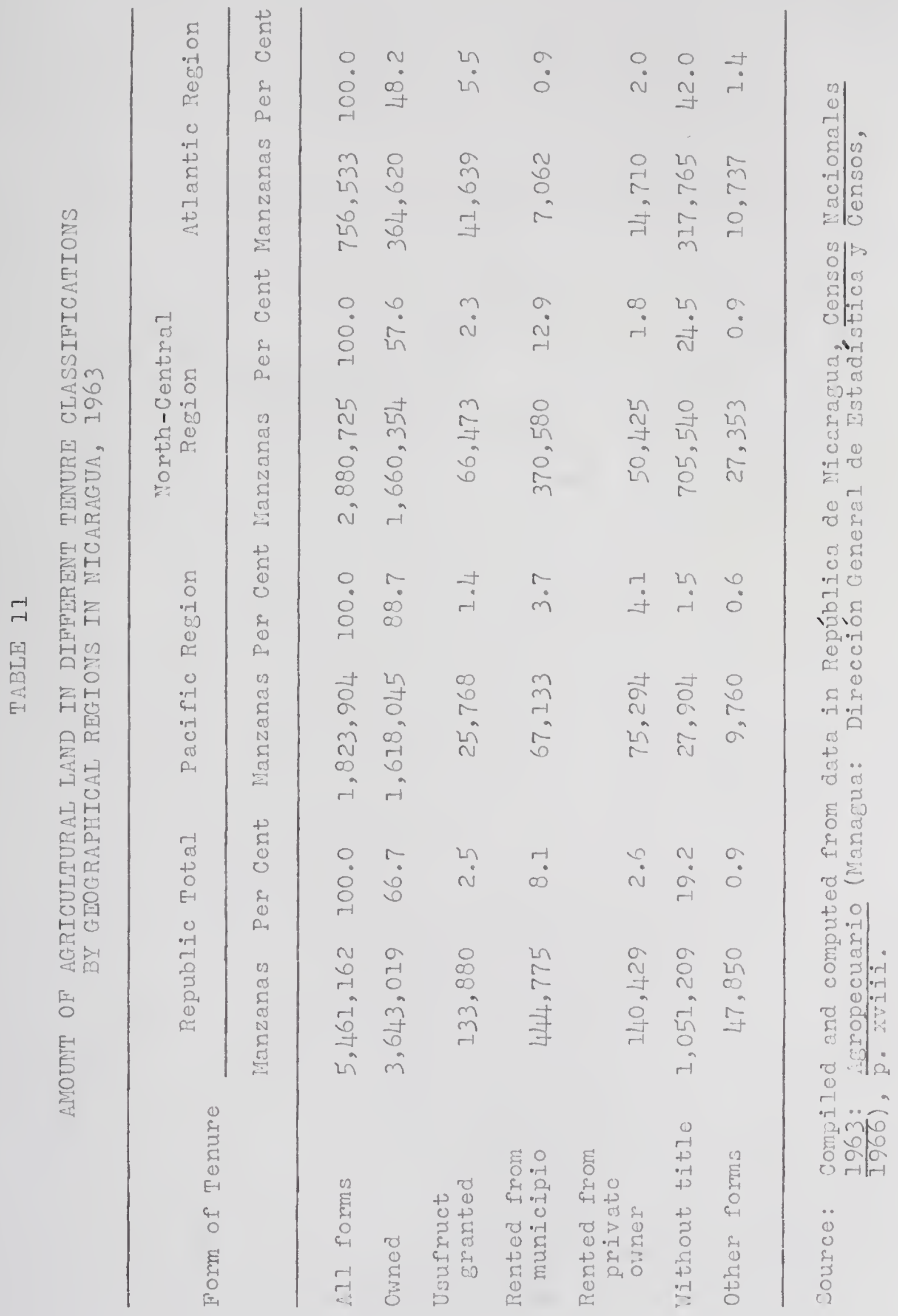


explotaciones agropecuarios and also the area in each of the census tenure categories in the three geographical regions. Table 12 gives further details of the different rental arrangements. Table 13, which gives the occupational activity of the rural population, is also helpful in indicating the distribution of the rights to the land in the different geographical regions.

As the data in these tables are analyzed, some interesting observations can be made in relation to regional variations. In the Pacific region the proportions of the following are the highest: (I) owner-operated establishments and area of the same; (2) cash-rented establishments and area of the same; (3) laborers and employees; and (4) sharecropper units and area of the same. This also is the region where the proportions of the following are the lowest: (I) patronos and self-employed; (2) usufruct and comunero-operated establishments and area of the same; and (3) land area operated without legal title.

It would appear that there are some contradictions when the high proportion of owner-operated explotaciones is compared with the low proportion of self employed and the corresponding high proportion of laborers. These apparent contradictions are explained by the fact that the Pacific region is characterized by minifundia, which inflate the listing of owner-operated holdings; yet these "owners" gain most of their livelihood by working as laborers or 


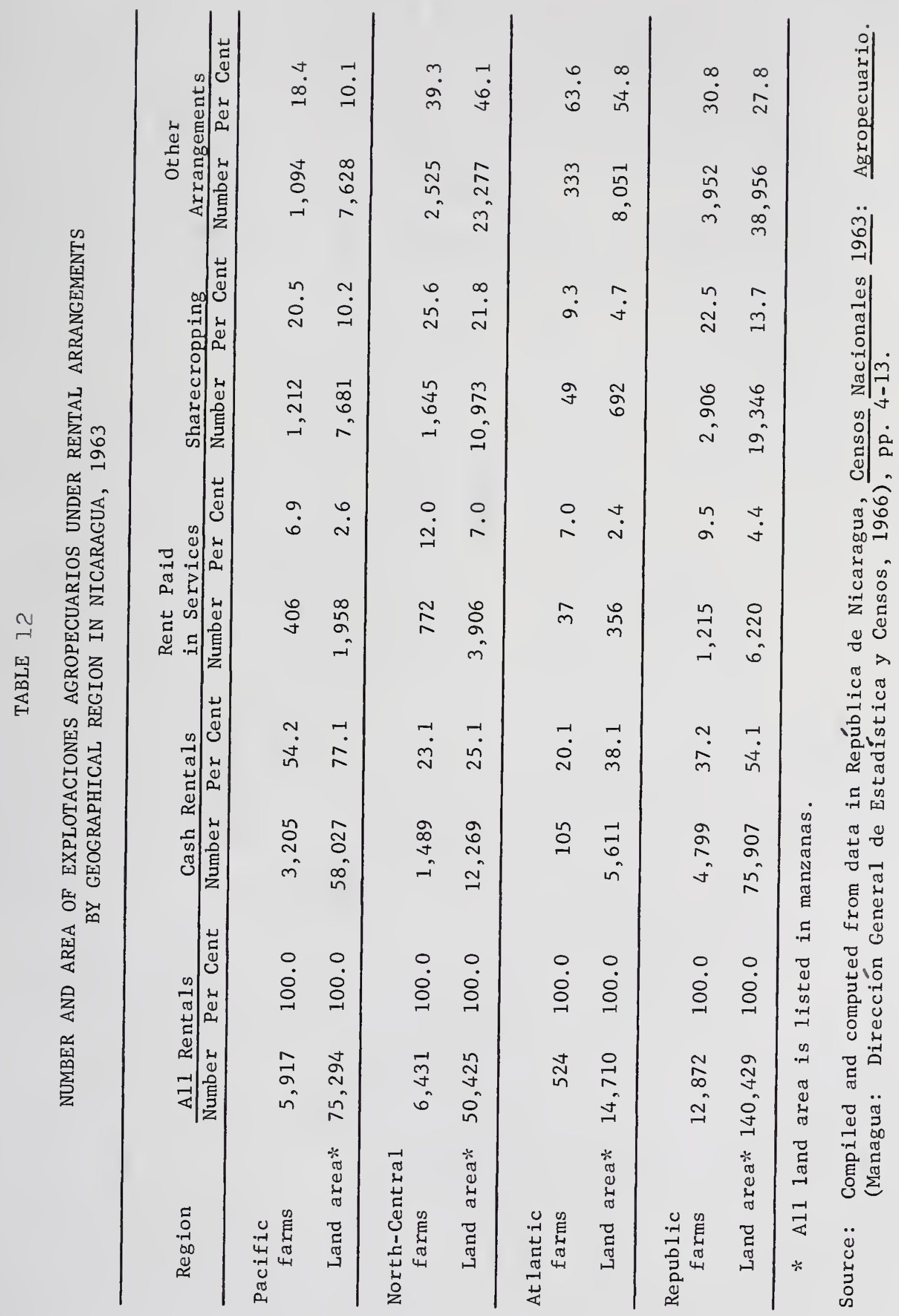




\section{TABLI 13}

NUIBER OF ECONCNICALLY ACTIYG PERSONS IT THE RURAL PCPULATION ACCORDITG TC OCCUPATIONAL LEYEI AND GEOGRAPHIC 1 L REGION IT NICARAGUA, 1953

Pural population

Economically Active

Pacific

Rezion
Torth-Central Region
Atlantic Pegion
RepubIic Total

Owner-emplojers

Iiumber

Per cent

Implojees

I'umber

Per cent

Iaborers

Tiumber

Per cent

Lelf employed

rimber

Per cent

Unpaid family

liorlers

irumber

Per cent

Unclassified

personnel

-rumber

Eer cent

motrl population

Number

Per cent
1,589

5,095

1. 3

14,036

11.8

59,012

49.7

28,048

23.6

16,021

13.5

170

158

0.1

0.1

118,876

100.0
34,411

$24 \cdot 2$
142,272

100.0
7,378

1.6
6,643

$27 \cdot 3$
26,931

9.4

5,064

110,967

20.8

38.9

82,807

29.0

41.3

57,075

20.0

Source: Compiled and computed from data in República de licarafus, Consos incionoles 1953: Ponlación Yolumen III (Mansgua: Diración Generil de zstádistica vensos, 1967 ), pp. 110-137.

24,370

100.0
285,518

100.0

\section{0}

C. 2 
employees and should not be considered as farm operators at all. At the other extreme there is a high proportion of latifundia, which accounts for the large area in owneroperated units. The high proportion of laborers, employees, and sharecroppers indicates a greater concentration of the rights to the land in the hands of a few in the Pacific than in any other region of Nicaragua. When the pertinent data are brought together, it appears that less than onethird of the farm personnel in this region are responsible for decision-making of the kind required of farm operators.

As the North-Central region is compared with the rest of the Republic, it is found to be neither extremely high nor low in most categories. It does have the highest proportion of usufruct and land used by comuneros and has moderately high proportions of sharecroppers and area attributed to them. It also has the lowest proportion of land that is rented for cash. In this region, the rights to the land seem to be more evenly distributed than they are in the Pacific. Approximately one-half of those related to the land apparently qualify as farm operators. However, the duration of these rights is insecure as can be seen in the large proportion in usufruct, establishments on land belonging to the municipios and land operated without title. Even the rights of decision-making are limited if the duration is insecure. 
A number of extremes can be observed in comparing the Atlantic region with the rest of the Republic. It has the highest proportion of: (I) patronos and self employed; (2) establishments and area of the same operated without legal title; and (3) establishments and area of the same operated under "other forms," which includes colonos. This region has the lowest proportion of: establishments and area of the same that is owner-operated; (2) laborers and employees, and (3) establishments listed as sharecropper units and area in the same.

The Atlantic is a frontier region, and as the data indicate, the rights of decision-making are widely distributed among those who are related to the land. Yet, the duration of these rights is more in question here than in any other region. The resulting combination of circumstances relating to property rights to the land is less favorable here than in the North-Central area.

Variations in Tenure Status in Nicaragua According to Size of Farms and Land Use

Data showing variation in tenure status according to size of farms are given in Table 14. In those establishments of less than five manzanas in size, the two major proportions are renter-operated ( 33 per cent) and owner-operated ( 31 per cent). The amount (13 per cent) of land operated on a usufruct basis is also significant. 
TABLE 14

ANOUNT OF AGRICULTURAL LAIT IN DIFFERETT TENURE CATEGORIES ACCORDING TO SIZE OF ETPLOTACIONES AGROPECUARIOS

IN NICARAYUA, 1963

Tenure

Size of Establishments\%

Categories

Under $5 \quad 5-49.9 \quad 50-2499.9$ Over 2500 Total

Owned

$25,859 \quad 362,375 \quad 2,168,853 \quad 1,085,932 \quad 3,643,019$

Usufruct

oranted

$11,002 \quad 48,059 \quad 74,819$

$1.33,880$

Rented from

municipio

4,249

91,793

340,793

$7,940 \quad 444,775$

Rented from

private

owner

Total

$28,215 \quad 54,908$

56,506

800

140,429

Cash

11, 291

20,365

43,451

800

75,907

Services

2, 450 3,001

769

6,220

Share

$7,380 \quad 11,064$

898

19,346

other

$7,090 \quad 20,478$

11,388

38,956

iithout title

$8,381 \quad 143,772$

892,456

$6,6001,051,209$

other forms

$6,664 \quad 18,956$

22,230

47,850

AII catesories

(manzanas)

$84,370 \quad 719,863 \quad 3,555,657$

$1,101,272 \quad 5,461,262$

All categonies

(number of farms) $36,206 \quad 43,706$ 22,119 $170 \quad 102,201$

* In manzanas.

Source: Compiled and computed from data in República de ricaragua, Censos Macionales 1963: Ajropecuario (Hanucua: Dirección General de Estadística J Censos, 1966), pp. 95-100. 
of the establishments of 5 to 49.9 manzanas in size, fully one-half are owner-operated, one-fifth are operated without legal title, and 14 per cent is used by those who rent from the municipios.

In the establishments of 50 to 2,499.9 manzanas in size, almost two-thirds (6I per cent) is owner-operated and approximately one-fourth is operated without legal title. This circumstance deserves special attention because a total of 1,051,209 manzanas of agricultural land in Nicaragua is operated in this way, and 892,456 manzanas (85 per cent) are in this size category. Further attention can be directed to the municipio lands, which account for only 10 per cent of the land in this size category but do include 79 per cent of all of the 444,775 manzanas of municipio lands of the Republic.

In the establishments of 2,500 manzanas and over in size, almost all (98 per cent) are owner-operated. The rest of the tenure categories involve insignificant amounts of land when considered on the basis of size or in relation to the totals for the Republic.

Some general observations can be made in the relationship of tenure categories and the size of establishments. As the size increases: (1) the proportion of agricultural land that is used by owner-operators increases, and (2) the proportion of agricultural land that is operated on a usufruct basis decreases. The proportion of land used by 
comuneros and that operated without title both decrease as the establishments become extremely small or extremely large in size (minifundia and latifundia).

There are no cross tabulations showing the relationship between tenure and land use in the published census data. An indirect comparison can be made by using sizeof-farms data as the common point of reference. A high proportion of the small grains (corn, beans, and rice) is raised on the farms of less than 50 manzanas in size, and they are the ones which have the lowest proportion of owner-operators. Cattle, coffee, sugar, and cotton production are highest on the farms over 50 manzanas in size, and they are largely owner-operated. Further investigation is necessary to confirm these relationships.

\section{Other Aspects of Land Tenure} in Nicaragua

The present land tenure arrangements in Nicaragua can be traced to the same causes mentioned in relation to the size of agricultural establishments. The heritage of the Spanish conquest and colonization was that of a landed aristocracy and a large laboring class who lived in slavery or at a semi-servile level. Possession of land was a mark of power and prestige from the time of the introduction of Spanish culture into the territory which now includes the limits of the Republic of Nicaragua. It was natural that 
those who obtained land would seek to retain possession of it for themselves and their descendants. The articles of the Constitution and the related laws gave legal backing to property rights, with full sanctions of the state for any who did not respect them.

It is only recently that the idea of the land owner's obligations to society has been seriously considered. Actually little has been done in the way of significant taxation of agricultural land or even of that classified as latifundia. It also is only recently that there has been some question as to whether it is "just natural" for society to be divided into a small privileged landed aristocracy and a large mass of agricultural laborers. The fact that the Agrarian Reform Law is directed at the establishment of family-sized farms and offers owner operation to those now working as laborers gives evidence of this. Whether custom and law will implement this in any large degree remains to be seen.

For the approximate 75 per cent of those economically dependent on agriculture who are either laborers or who work places that are too small to qualify as family-sized farms, the present tenure arrangements contribute to their disadvantaged position. It is among these families that poverty, health problems, illiteracy, and general levels of living are the lowest. Above all, their participation in, and contribution to, the general development of society is very small. 
Two aspects of the relationships of man to the land discussed in this chapter: the nature of the bundle of property rights to the land in Nicaragua, and the way these rights are distributed among those who are related to the land. Land as an item of wealth differs in many aspects from other property, so that land tenure, or the legal relationship of man and land, is of importance in any study of society.

The history of property rights to the land in Nicaragua is much like that of the other Spanish American countries. Rights were defined in the Laws of the Indies and later in the Constitution of the independent Republic. The rights today are essentially in fee simple, as they have been since the founding of the Spanish colony. This means that the private owner has almost complete control over the land. The government retains the right of eminent domain, the right of taxation, subsoil rights, and the right to define the social obligations of land ownership. The government has exercised very little the rights it retains.

Although the 1963 Census shows that a high proportion of the land is in establishments that are owneroperated, close analysis of occupational data demonstrate that farm laborers represent fully as large a proportion of the farm personnel as do the operators. 
The Pacific region is characterized by high proportions of laborers, low percentages of the self employed, and a poor distribution of the rights to the land. In the North-Central and Atlantic regions there is a better distribution of the managerial rights but a lack of security in the duration of all rights to the land. As the size of establishment increases, there is a proportional increase in owner operation, a proportional decrease in tenancy, and a proportional decrease in land operated on a usufruct basis. Relatively little of the land owned by the municipios is used in agricultural establishments that should be classified either as latifundia or minifundia. Owner-operators cultivate most of the land in units that qualify as family-sized farms.

only indirect observations can be made as to the relationship between tenure and type of farming. The data suggest that small grain crops for local consumption are raised by those with relatively few rights to the land, while cattle, coffee, sugar, and cotton are produced by those who are owner-operators.

There is little doubt that the 1 arge proportion of those related to the land who have few rights and receive small benefits are at a disadvantage economically and socially. The same observations as to health, education, and general levels of living could be made here that were made in the chapter on size of farms. Just as output 
efficiency in the agricultural pursuits of these workers is low, their contributions to the general well-being of society also are small. They see new opportunities in the cities and are ready to migrate as soon as the opportunity arises. 


\section{CHAPTER V}

\section{IAND DIVISION, LAND SURVEYS, AND LAND TITLES}

When the possession and control of land is to be distributed among individuals, there must exist accepted ways to measure, to divide, and to record the titles to the tracts given to each person. In a society that recognizes the institution of private property, these functions are accomplished through land surveys, systems of land division, and procedures for titling.

These three aspects of man's relation to the land are closely interrelated. Unless an adequate inventory of the total land area has been made and major divisions have been indicated by some kind of markings, it is almost impossible to assign tracts to individuals with any degree of accuracy. An accepted pattern of land division also must be recorded on paper in such a way that it conforms to the way things actually are on the land. Only when all three of these aspects have been worked out together can legal ownership of a specific tract of land be certain. Two especially important aspects of land division are considered in this chapter. First, are the surveys definite, determinate, and permanent? Second, how does 
the system of land division affect social interaction and the resulting social welfare? ${ }^{1}$

In Nicaragua it is no longer possible for a man to find a piece of land to his liking and physically defend it against other claimants. Furthermore, in the absence of a definite, determinant, and permanent system for surveying land, many difficulties and problems have recurred in recent times in man-land relationships in Nicaragua and a number of the other countries of Latin America. The following passage from my field notes illustrates the nature of some of these problems.

(San Carlos River, Costa Rica, 1962) Don A. spent considerable time telling me about the problem of linderos (property lines) with his neighbor, Sr.C. When he was cleaning the line last week, he was told that the property limits were only to the edge of the stream and did not continue in a straight line. This makes a difference of about 10 manzanas of land, although it is still in virgin forest and both land owners have plenty of land that has not been cultivated. Neither has legal title to the land, although both have lived in the area for some time. As there is no written description of the boundaries, definition of the boundaries depends on the word of each. If a court case were to come up, which is likely, it would depend on witnesses and would be a distasteful case. This is the kind of situation which caused the shooting of a man near the Tres Amigos River last year. Everyone on the river is trying to get some legal recognition of his right to the land.

ICf. T. Lynn Smith, Colombia: Social Structure and Process of Development TGainesville: University of Florida Press, 1967), pp. 147-49. 
This case is typical of thousands of social problems caused by the lack of adequate surveys and titles records in many of the Latin American countries.

Unless a survey is based on permanent and easily defined reference points, further problems arise. For example, there are some farms near the one mentioned above where the river, which forms parts of their boundaries has changed course, and this has given rise to serious disagreements. When unstable features such as meandering streams are used in the descriptions of boundaries of properties, an adjustment is necessary after each change. Men are not always disposed to make these changes readily, and friction and conflict often result.

Where new lands are to be settled, the need for adequate land division, surveys, and titles is primary. Even though the land may be settled on a volunteer or spontaneous basis, it is less costly to set up efficient systems before settlement begins.

\section{Types of Land Surveys}

Systems of land division may be classified generally as: (1) metes and bounds, (2) river front patterns; (3) rectangular systems based on astronomical observations, and (4) other special systems. 2

2. Lynn Smith, The Sociology of Rural Life (New York: Harper and Brothers, 1953), pp. 246-73. 
The system of metes and bounds is a haphazard method that is used where land is abundant. Such markers as trees, streams, and other physical features are used to indicate the limits of the various claims. This system has been used in the settlement of new areas throughout the world and was extensively used in the settlement of what is now the United States during the period from about 1750 to 1787. The cost of rectifying difficulties arising from this pattern at a later date is high and is levied on the society as a whole. Not only are there constant disputes over boundaries, but the helter-skelter settlement pattern allows for little of the social interaction which is necessary for community operation.

River front patterns develop where rivers are the natural means of transportation. This became a highly developed cultural pattern in Europe and especially among the French. The pattern has generally evolved by limiting the amount of frontage given to any one settler, and allowing greater length to the boundaries running from the river. This syster has at least one semipermanent point of reference, the river -- a more enduring marker than those usually used in metes and bounds. The river also serves as a common system of transportation, which allows for a settlement pattern that promotes social interaction. Often the farms are narrow enough so that the homes can be rather close together on both sides of the river. 
Unfortunately, the river front pattern does not provide permanent boundaries: when the stream changes the course and the banks of the river are no longer at the same site, many tremendous difficulties arise.

Rectangular systems based on astronomical observations utilize the same measuring techniques as those used in calculating the latitude and longitude of the earth. As the ultimate sources of the fixed points used in this system are astronomical and do not depend on "the shifting sands" of the surface features of the land, a farm is located in a specific area with dimensions that will not change through the years and can be easily remeasured at any time. As roads are built into this system and the farms are divided into rectangular plots, a grid or checkerboard type of arrangement is formed, such as is found in most of rural United States today.

other forms of land division have been devised in specific circumstances. In Cuba, a circular system was used by the Spaniards in allotting land to the early conquerors. This pattern seemed to work reasonably well while there was plenty of land available, but later it caused many boundary disputes. The system has many of the characteristics of indiscriminate location, as can be observed today when flying over Cuba. One source of friction has been the odd-shaped corners of land that are left over between the circles. These little fragments are 
called realingos, and the case of Realingo Dieziocho is one of the historic land disputes of the Cuban Republic. 3 Two aspects should be considered in evaluating the different systems of land division. The first is mathematical and the second is social. Mathematically, the system must describe the tract accurately, it must locate it in relation to other tracts, it must not change over time, and all of the calculations should be simple. Socially, the system of land division should facilitate interaction so that goods and services can be provided economically and so that community problems can be solved cooperatively. Of the different patterns mentioned, only the rectangular type or its modifications fit the first requirement; the river front type satisfies the aspect of social interaction; and ordinarily the system of metes and bounds satisfies neither of the requirements. 4

Contemporary Land Division, Land Surveys, and Land Titles in Nicaragua

Presently in Nicaragua the methods used for surveying, for land division, and for recording titles to land leave much to be desired. The present surveys are indefinite, indeterminate, and impermanent. A system that

${ }^{3}$ Lowry Nelson, Rural Cuba (Minneapolis: University of Minnesota Press, 1950), p p. 84-90.

${ }^{4}$ Smith, The Sociology of Rural Life, pp. 263-73. 
provides accurate and detailed description of all lands within the national territory is a prerequisite to division and titling of the land. No such accurate method of survey of lands was devised in Nicaragua before the process of division began, nor has there been one since. 5

In an attempt to correct this situation, Articles 122 and 123 of the Agrarian Reform Act of 1963 provided for a cadastral survey. This, however, actually is considerably more than a real property survey. Thus, after a lengthy study, the following recommendations were made as to the procedure that should be used:

1. A cadaster should be started by the Institute under the National and Municipal Lands Commission created by Article 122 of the Land Reform Act. The photograph or map portion of the cadaster should be graphical, based insofar as possible on representations of the property boundaries as shown on the new $1: 20,000$ scale aerial photography. No attempt should be made at this time to develop a mathematical or legal cadaster. If in time such a cadaster should become desirable, the Cartographic Agency should undertake its construction. At the present time the necessity for such a cadaster is far in the future. In any event, the increasing use of courses and distances in boundary descriptions will gradually provide much of the data necessary for a numerical cadaster.

2. The various items constituting the registry portion of the cadaster should be entered

5 Pan American Union, Central America (Washington: Inter-American Comittee for Agricultural Development, $325,3-E-7185)$, p. 45 . 
on punch cards for recovery by automatic data processing. Such cards can furnish rapid information on the ownership and economic factors affecting land. Among these are statistical data, census information, and natural resource elements.

3. Consideration should be given to establishing a regular mathematical subdivision system of laying out tracts of land in large areas to be settled. A large portion of the public lands in the Atlantic drainage not settled at present could thus be surveyed. A description of the system used in the United States for the survey of public land goes beyond the scope of this report. However, it is believed that the use of the United States system of surveys or some comparable system should be explored. 6

Aerial photographs will facilitate future surveying and mapping work. As of 1966 it was calculated that vertical photographs on a medium scale (scales above $1: 30,000$ ) were available for from 70 to 90 per cent of the total area of the Republic of Nicaragua. 7 Figure 2 shows the extent of topographical maps that are available. Figure 3 gives the same information concerning planimeter maps. This system is a rectangular one and has as its base, fixed astronomical points of reference.

Local surveys are made when needed in connection with large land transactions and especially when bank

${ }^{6}$ Clark L. Gumm, "Report on the Establishment of a Cadaster for Nicaragua" (unpublished report by the Chief Cadastral Engineer of the Bureau of Land Management of the United States Department of the Interior, 1965), pp. 24-25.

${ }^{7}$ Louis E. Heaton, Rural Development in Latin America (New York: American International Association, 1963), p. Il. 


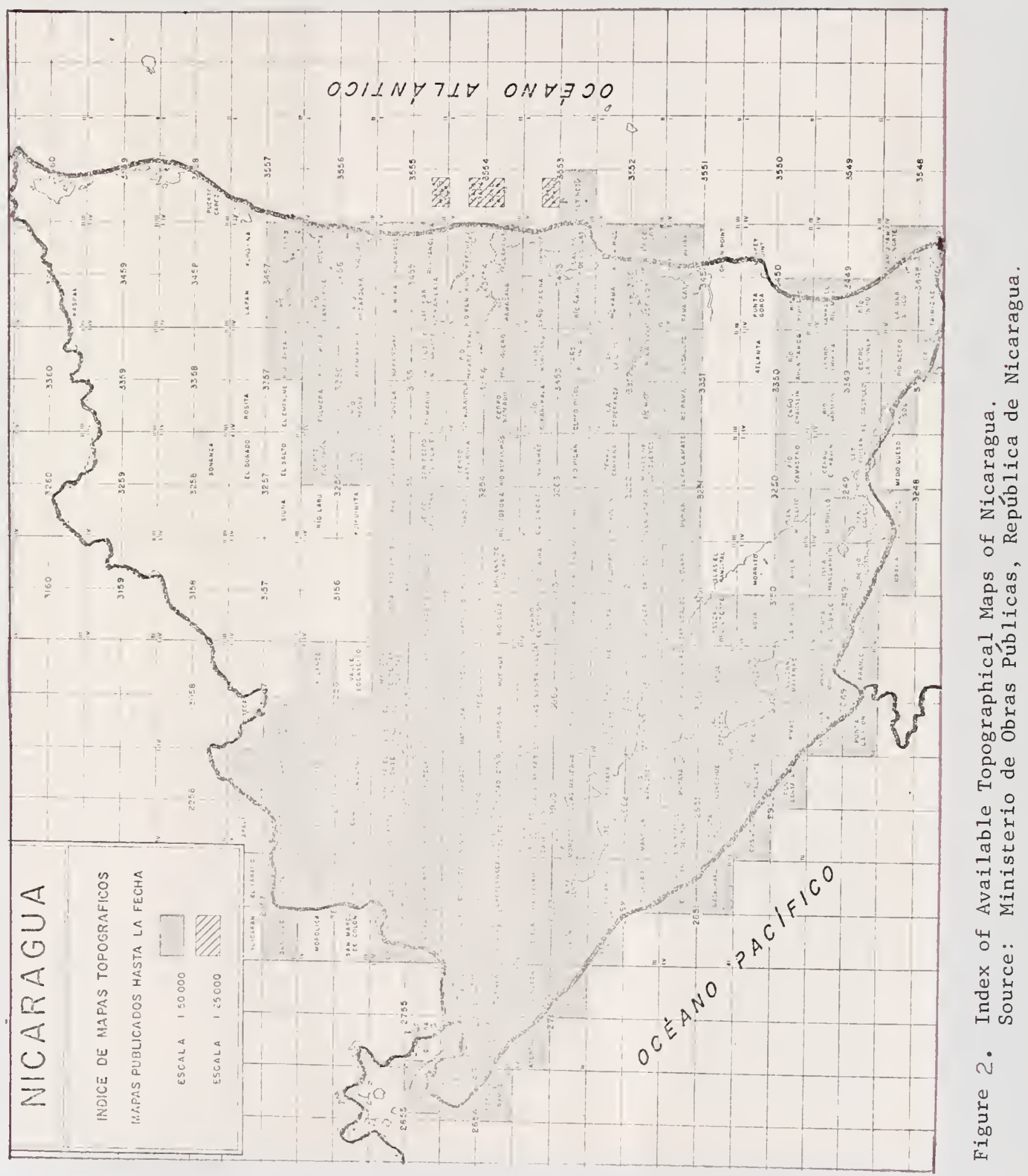




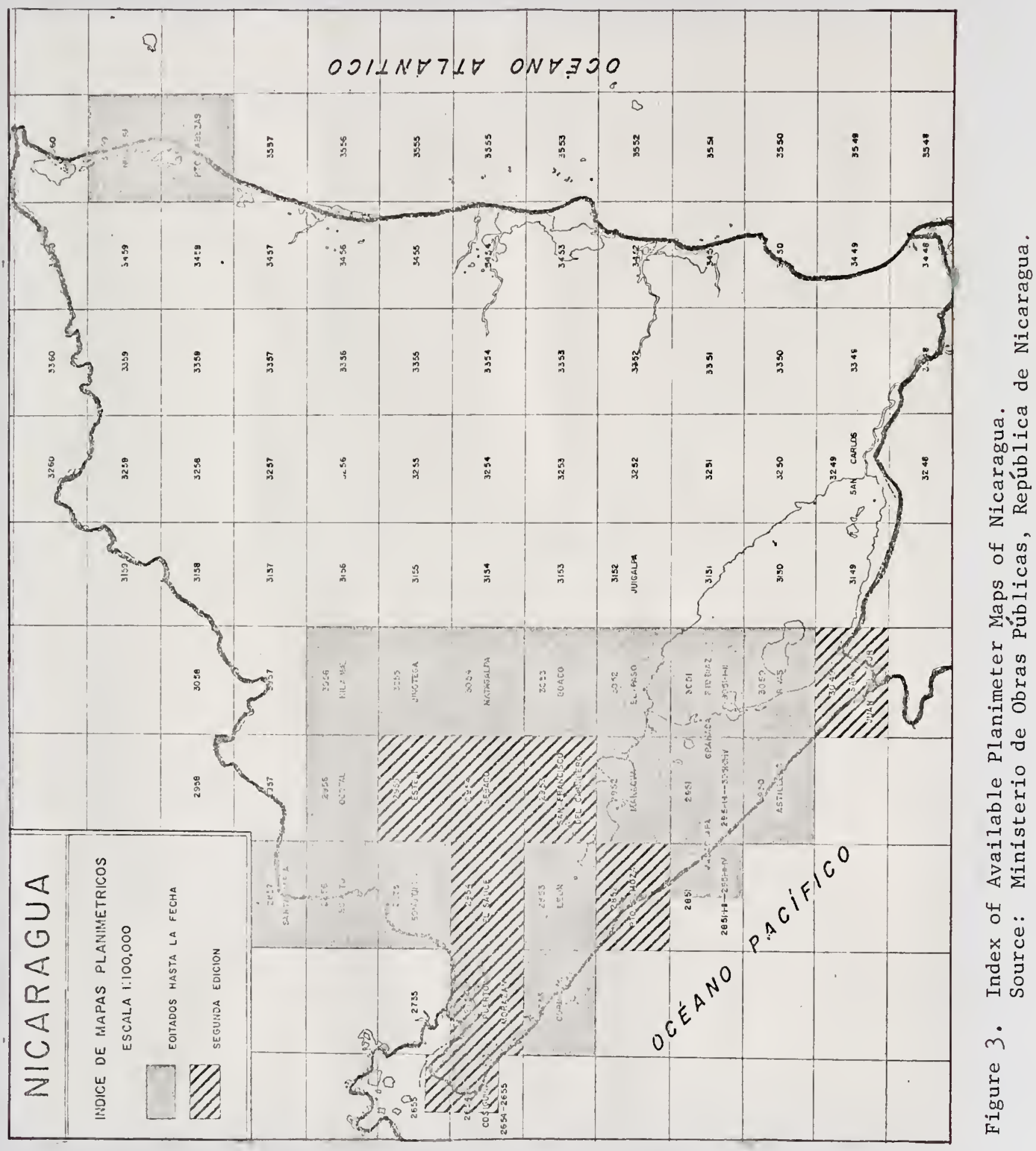


credit is involved. It is based on metes and bounds. (See Figure 4.) Yet, the process is expensive on a local and isolated basis and is used only in exceptional cases. Because of a lack of enabling legislation, it appears that it will be some time before a rectangular survey method is used in land division and titling.

In common transactions also, property boundaries are described in metes and bounds. Other systems of land division are almost nonexistent in Nicaragua. Natural objects or local landmarks are used as reference points. The following entries found in the records of the property registry of the departamento of Masaya give ample evidence of this. The registry was established in 1883;

before that time all property in Nicaragua was registered at two locations, León and Granada.

Buying and selling entry number 22, property registry number 20. Sr. don Manuel Barrera, of legal age, a farmer near this city and a resident of Tisma, sells to don Marcelo Vega, of legal age, storekeeper of this neighborhood, sixteen manzanas of land located in Tisma bordering on the east with land of don Jose Jaime, with a road between; on the north with land of the buyer, don Marcelo Vega; on the west with unclaimed land; and on the south with the pasture of don Jose Juan Baray, with a road between; for the sum of sixty pesos simple, $\$ 60$. This is all in the public records as presented before the scribe don Jose Antonio Solano at eleven o'clock on the twentieth of January of the year eighteen hundred and eighty-three. Signed with the interested party at three o'clock on Tuesday the twelfth of June of eighteen hundred and 


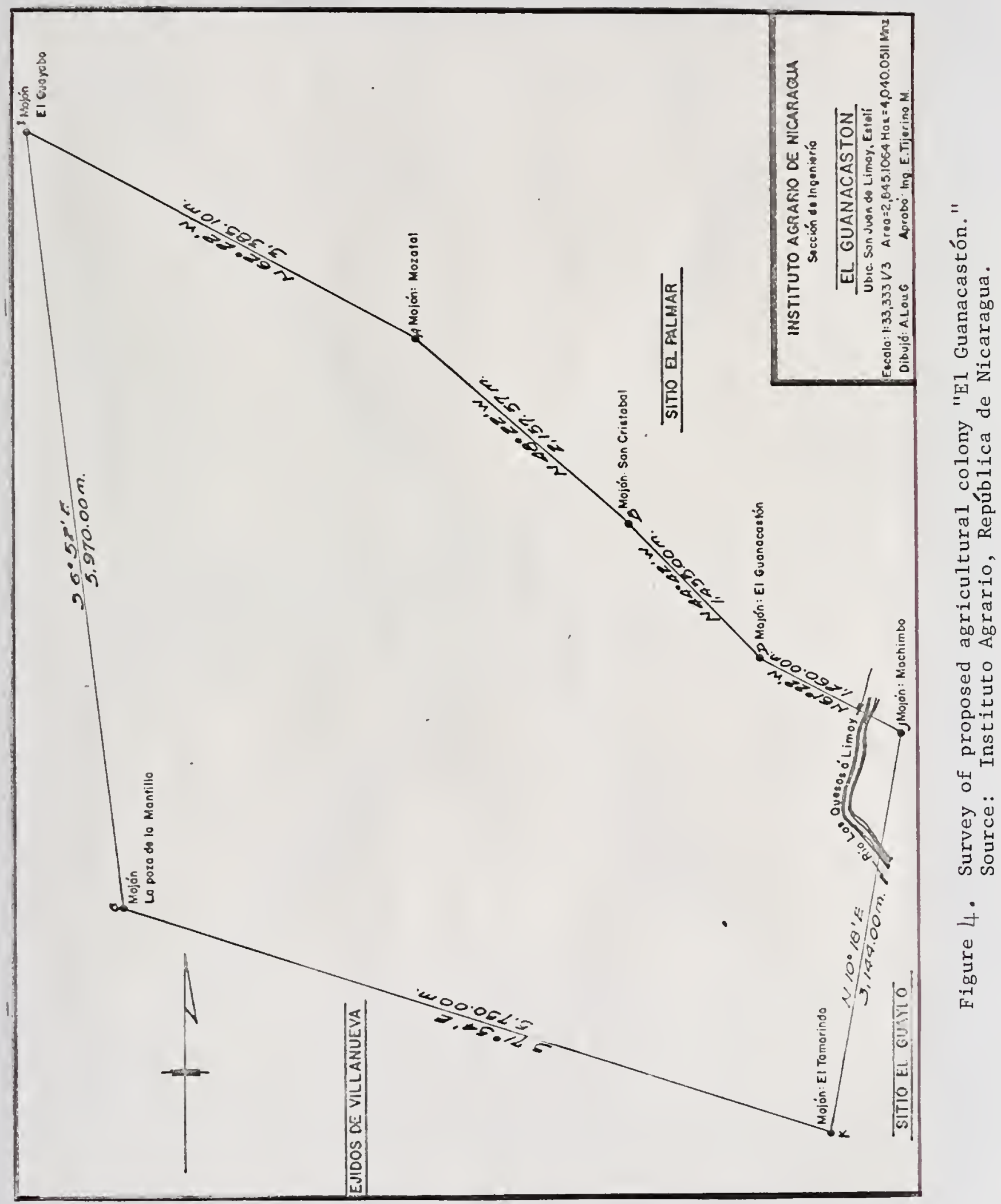


eighty-three. Amended by Manuel Barrera. (Signed: Marcelo Vega and Grego Poiginer)

The above example was one of the first properties to be registered in Masaya. Later in the same year the following entry was made in reference to another property:

Buying-selling report number 107: Enfracio Perez, of legal age, laborer and resident of Sanbrano, sold to don Sirando Plata, of legal age and a resident of this locality, a right to land in the place known as Santa Cruz for the sum of thirty-two pesos strong (\$32) with location to the north of this city and approximately four lequas (about 20 kilometers) in distance and which borders with land of don Trincito Miranda on the east; with the town of Nindiri on the west; on the north with the plot of don Jerónimo and on the south with don Efraín. Signed by the interested party in Masaya at $40^{\prime}$ clock on the first of December of eighteen hundred and eighty-three. (Signed: Emedardo Sambrano) 9

After 1904 a new system of property registry was used, but the method of describing the land remained much the same. The registry books were slightly smaller, but each entry was made across the two open sheets instead of on a single sheet. There was room in the registry for any special conditions of the sale, cancellations, and any mortgages levied on the property. The following is part of an entry made in 1907:

Rustic farm number 11: . . a farm of fruit trees of approximately twenty manzanas situated

${ }^{8}$ República de Nicaragua, Registro de Propiedad: Año 1883 (Masaya: Oficina de Registro Público, 1883). 
in the valley of La Laguna in the proximity

of Masaya with the following boundaries:

on the east with the land of Jacinto Pilarte and Celedino Morales; on the north with that of Julio Espinoza and Juan Rives; on the south with those of José María and Juan Rivas...10

Even this system of description is without fixed points that can be used to locate this tract as a unique piece of land.

Today the description of property is much the same as it was in 1883 and earlier. One of the entries made in the 1968 registry reads in part as follows:

Book 359, number 24554: . . a rustic farm located within the jurisdiction of El Raizón of this departamento, composed of land that measures thirteen thousand three hundred and thirty-three square varas (one vara $=32.87$ inches) within the following boundaries: to the east a neighborhood road and land of Pedro Ignacio Reyura López; to the west, the successors of José de Jesús Miranda; to the north, Eusevio Reyura López; and to the south, Pedro Ignacio Reyura López. This farm that is now listed as number 24554 is a part of the larger farm listed as number 20543 in folder 2 of volume 162 ...11

All titles of ownership of land are recorded in the Registro de Propiedad (property registry) which, as in the case of Masaya, is located in the capital cities of each

$$
\begin{aligned}
& { }^{10} \text { Ibid., p. } 24 . \\
& { }^{11} \text { Ibid., p. } 82 .
\end{aligned}
$$


of the 16 departamentos. The property registry is combined with an office for the registry of mortgages and a registry of persons. Leases may be registered, but the practice is not common. As can be observed in the sample entries, each title transaction is given a number, and the registry volume and year are recorded. The owner of the property receives a true copy of this entry, and it serves as documentation of his rights. These registry books are open to the public so that anyone can investigate a transaction.

In certain special cases, a double entry is made in reference to one piece of property. If a farm extends over departamento boundaries, then it will be listed on the books of each departamento involved. Double entry is also used to record large farms that are subdivided for leasing purposes. 12

Registry is only one aspect of the titling procedure. Early titles came from direct grants or purchases from the Spanish Crown or the governments that were established later. In recent times, titles have been secured through prescription, the Agrarian Law of 1917, and the Agrarian Reform Act of 1963. The procedures for securing title through prescription and through provisions of the

12 Alfonso Blandon, Land Tenure in Nicaragua, Master's thesis (Gainesville: University of Florida, 1962), p. 15. 
Agrarian Law of 1917 are outlined in the following

paragraphs:

PRESCRIPTION -- Prior to adoption of the Constitution of 1939, all national lands were subject to prescription in the same manner as private lands. One exception was public land if possession was based on a "just" title. A just title is one which, although transferring ownership, involves some circumstance that renders it ineffective of itself as proof of alienation.

Where lands were held under a just title, prescriptions would run from the date that title was recorded in the Public Register Office. After ten years of occupation and use, the claimant could go before the court and present his witnesses and bona fides. If the judge decided that ownership was in the petitioner, he would issue a decision to that effect. The decision would provide the basis for a clear title for recording in the Property Register. Similarly, clear title could be obtained after 30 years without a title.

The possibility of prescription is a constant threat to private land owners and is largely responsible for the large number of wellbuilt fenced enclosures in Nicaragua.

AGRARIAN LAW OF 1917 -- This law, as amended at various times until 1952, provided another method for the disposition of public lands. Under this law, public lands, with some exceptions, could be granted by the Executive with or without payment.

Under the purchase requirements, a written application for an allotment of public land was made to the head of the Department. The application described the lands desired and furnished other pertinent information. Within three days after receipt, a hearing was held at which witnesses testified as to the physical condition and other circumstances which might affect an allotment. If the decision was 
favorable, the land was classified for allotment, and a public notice was issued giving 30 days for the presentation of protests. After consideration of any protest, the application could be allowed. The lands were then assessed and the purchase price was determined. The cost, depending on the type of land, varied from 30 to 150 córdobas per hectare. In addition the land also was subject to surcharge for commercial forest lands and accessibility to arteries of commerce. If the land was not suitable for agriculture or stock raising, the price per hectare was 20 cordobas.

The law required that after appraisal a surveyor's report should be submitted and if all was in order the land was marked out on the ground. A provisional title could be issued at this time if a bond was posted to insure payment. After five years an inspection was made to see if the cultivation requirements had been met. If less than half the land had been cultivated, only title to twice that in cultivation could be obtained. Within the meaning of the law, stock raising could qualify under the cultivation requirement. When all requirements were met, final title was issued which could be recorded in the office of the Public Register.

There is some uncertainty as to whether the Agrarian Law of 1917 is still in effect, although the Land (Agrarian) Reform Act of 1963 provides that all provisions of the Agrarian Law in contradiction with the later act are repealed. However, the Agrarian Institute comes into control of national lands only after such lands are transferred to their jurisdiction by the Executive. To date few transfers have been made. Because of this situation, the point has been made that settlement under the Agrarian Law is still permissible.13

13 Gumm, op. cit., pp. 3, 4. 
There are three main objectives in the titling procedures outlined in the Agrarian Reform Act of 1963: (I) the formation of new agricultural colonies on unused national lands; (2) the clarification of titles of those now living on municipio lands; and (3) clarification of the title of those on land that is of questionable ownership. The titles of ownership will be given to the agricultural colonists when they have met all of the stipulations of the original application contract, after they have paid 25 per cent of the value of the property, and if, at that time, the whole farm is under cultivation. 14 at the latest report 1,31l titles have been given out under this program. ${ }^{15}$ Apparently little action has been taken with regard to the other two aspects of the Agrarian Reform Act of 1963.

Causes of the Contemporary Situation

The present situation is a reflection of the past. Land has been abundant since the Spaniards first set foot on Nicaraguan soil. There was little reason why land should not be made available to those who could make it

14 República de Nicaragua, Colonias Agrícolas

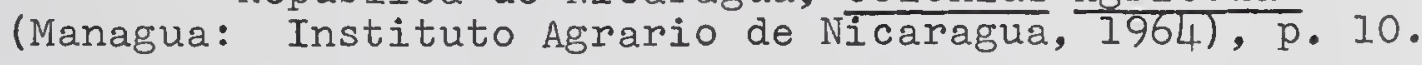

15República de Nicaragua, Memoria 1966 (Managua: Instituto Agrario de Nicaragua, 1968), p. $\frac{196}{26}$ 
productive. The desire for land was also strong, and these two conditions fostered land grabbing. It was to the advantage of those receiving land that the perimeters be "open" at least on one side. No one questioned the custom of extending the boundaries to include much more than the original grant.

Even today, Nicaragua has a relatively low population density, and the amount of potential farm land is as great as the amount now in cultivation. The past custom of extending boundaries and the present abundance of land have made it difficult to change attitudes toward land surveys, land division, and titling procedures.

There are two other factors that tend to maintain the present situation: the cost involved because of the geographical features in making an adequate survey, and the property taxes that will be levied once the farms are clearly defined. The Agrarian Reform legislation has contemplated such a survey as a basis for land taxation but, curiously enough, the enabling laws have not been passed by Congress. As with any projected social change toward which there is resistance, it is useful to discover who is benefiting from the situation as it presently exists. It would appear that the land owners benefit because taxes cannot be levied, and the lawyers benefit because there is an increasing amount of litigation. 
Results of the Contemporary Situation

The lack of land surveys, of a clear description of land divisions, and of accurate titles has undoubtedly contributed to the low levels of living found in the rural areas. Low investment is a characteristic of Nicaraguan agriculture, but there is little incentive to invest unless the boundaries and titles are beyond question. If the title to the land is not definite and clear, it is almost impossible to get credit to invest in improvements or even in production enterprises. Without capital investments the output per person or per unit of land remains at a low level.

If social services are to be made available to the rural population, tax revenues must be increased. Already some attempts have been made to provide basic educational and health services to all areas of the Republic, yet taxes from the land represent only a small contribution to the national budget. Usually money from land taxes is applied directly to building roads and schools. Although no documentation is available, it is not unrealistic to suspect that unscrupulous people have taken advantage of the lack of clarity in land division and land titles. In dealing with rural people who are not too sure of their rights to the land, I have found that they live in fear of being manipulated so as to lose their land. 
Sometimes this anxiety is unfounded, but there have been enough cases to perpetuate apprehension in each new generation.

\section{Development and Trends}

Before the Spaniards came to Nicaragua, only simple maps were used by the natives to describe the limits of the land of each village. Any boundary disputes were settled by the tribal chiefs, and such differences probably were not a source of major conflict because land was plentiful.

Land division began almost immediately upon the arrival of the conquistadores. References to land are to be found in the earliest exchanges between the officials and the Spanish Crown. Individuals requested land in large quantities so that it might be occupied and brought into production. A further motivation was that the natives of the area might be Christianized. Often land was requested for its strategic location in the defense of an area.

Such a request was made by Capitan Gil Gonzales de Avila in a letter sent to the King of Spain in 1524. In this letter are a number of requests for mercedes (land grants), from which the following is extracted and translated:

A petition for 10 square leguas (one legua equals approximately four kilometers) of 
land that is located at the northern side of the mouth of the great fresh water sea and an equal amount at the southern side.16

This request was made by the capitan for himself and "to be granted in perpetuity to him and his offspring."

Land that was requested and granted was described with little regard for exactness. Descriptions might define a boundary as extending "to the borders of the deep stream," "as far as the crest of the hill," "to the limits of the land of Sr. X." In only a few cases were geometrical angles used to describe contingent borders.

As time went on, these transactions were handled locally. All privately owned land was registered in a local public office, and contracts for transfer of the land were known as asientos. The lack of accurate descriptions in the division and registration of lands was the cause of many disputes and litigation. This situation continues up to the present time.

A number of laws have been passed in relation to land titles and procedures for titling. Such legislation is included in the Civil Codes of 1871, 1904, and 1929; in the Commercial Codes of 1889, 1916, and 1949; in the Code of Civil Procedure of 1871, 1905, and 1950; in the

16 Andrés Vega Bolaños, Documentos para la Historia de Nicaragua Tomo Primero. (Madrid: Ministerio de Educación de la República de Nicaragua, 1954) p. 113. 
Mining Code of 1906; and in the Labor Code of 1945. These laws are in addition to the articles of the Constitution, and they relate to liens, mortgages, inheritance, sale-purchase contracts, foreclosures, establishment of boundaries, and modification and recording of deeds in the public registry. There is some question as to the constitutionality of some of these laws. ${ }^{17}$

Recently, there have been further moves "to put the house in order" in regard to land division and titles. The work of the National Agrarian Institute has been widely publicized. The fact that some rural people have received title to farm land has given hope to others. The mapping project is providing materials that can soon be used to equate visible boundaries with existing registered farms. Already, many farmers in the Pacific region have realized that a clear title with undisputed boundaries is necessary even if they have to pay taxes as a result. Land that rents for 300 córdovas a year per manzana can well afford the maximum tax of five córdovas per manzana. It is frequently commented in Nicaragua that much more can be done if Congress will pass legislation approving the proposed survey and titling procedures of the Agrarian Reform Law.

17 Blandon, op. cit., p. 19. 
Land division, land surveys, and land titles are those means by which land is measured, divided, and recorded. The methods of accomplishing these functions are important in a study of the relation of man to the land because the property rights to the land pertain to a specific land that is in a specific geographical location. The lack of clarity in regard to land rights is the cause of many social problems in the rural world today and is partly responsible for slow economic development in some areas.

The contemporary system of land division that prevails in Nicaragua is that of metes and bounds.

The lack of a survey of the lands has made it impossible to develop any accuracy in the division and description of individual farms. Consequently there is much difficulty in including the exact location and dimensions on the land titles, as can be observed in the entries in the property registry.

Some of the reasons for the present situation are: the abundance of agricultural land, the strong desire for land acquisition, the custom of extending boundaries of areas claimed for those legally justified, the high cost of surveying because of the geographical features of the country, and the desire of owners to keep their land off the tax rolls. 
Some of the effects of the present situation are: a general insecurity in the property rights to the land; lack of investments in agriculture; lack of tax revenue for schools, roads, and health facilities; constant disputes over boundaries; and a slow rate of agricultural development.

Undoubtedly the historical development of this aspect of man-land relations in Nicaragua is a factor in the present situation. Before the Spaniards came, little emphasis was placed on exact boundaries because there was abundant land. During the time of the Spanish colony, some attempt was made to describe the grants of land made by the King, as well as later subdivisions of these grants. Things have changed little up to the present time. The Agrarian Reform Act of 1963 proposes major changes, starting with a national survey as the basis for clearing up present disputes over boundaries and giving an exact mathematical basis for future divisions of public lands. Also contemplated are clear titling procedures and an equitable tax on land. However, these measures are dependent upon enabling legislation, which has not been passed as jet. 
CHAPTER VI

SETTLEMENT PATTERNS

Settlement patterns denote the spatial arrangements of the dwellings of people living on the land; i.e. the manner in which the homes are arranged in relation to one another and to the fields which are used by the families living in them. There is a close relationship between settlement patterns and land division, land surveys, and titles.

Farming differs from most other occupations in the amount of space that is needed for production. The farmer has to make a choice of whether to have his house close to the land he works or close to those of his neighbors. If he chooses to live adjacent to other families, then village patterns of settlement result. If he elects to reside on the land, then scattered settlement patterns result. If the land is surveyed in certain ways, such as by metes and bounds, and is not part of a planned division scheme, then isolation of the various farm families may be great.

Although the settlement pattern is a choice that all those living on the land must make, it is not an individual choice. Like all cultural patterns, it develops 
over time and because of diverse circumstances, but once established, it is the accepted way of settling on the land and is difficult to change. ${ }^{1}$

\section{Principal Types of Settlement}

There are two aspects to be considered in evaluating settlement patterns: efficiency in social interaction, and efficiency in agricultural production. The two are often in conflict with each other, and the best arrangement may be one of compromise. These aspects can best be seen by examining the three patterns of settlement used by rural people to note the advantages and disadvantages of each. 2

In the village type of settlement, the dwellings are grouped together in some kind of village or hamlet. In this small center a school, a church, some kind of market or trading establishment, and a sports field are often found. Unless the space is limited, there may be near each house a small garden plot and even some barns or stables for animals. A Mexican agricultural village described in my field notes is an example:

(San Juan de Acosác, Mexico, 1965) San Juan is an agricultural village about an hour's ride

$I_{T}$. Lynn Smith, The Sociology of Rural Life (New York: Harper and Brothers, $\frac{19531, \mathrm{pp}}{1.99-200}$.

$2_{T}$. Lynn Smith, Colombia: Social Structure and Process
Florida
Press, 1967), pp. 257-58. 
on the bus from Puebla. It is at high altitude and specializes in vegetable crops. Surrounding the village are fields of carrots and cabbage as well as corn and alfalfa. Each of the homes in the village is surrounded by adobe walls. There are two entrances to each home: one is through the front door and the other is a solid wooden gate that goes into a courtyard.

At the home where I stayed there were grains and other products stored in the inner patio of the home. I also noticed that the courtyard was used for keeping the animals at night and for storing a small wagon and other farming equipment. There are always chickens in the courtyard and they sometimes enter the patio of the house. Along one wall of the courtyard was a planting of peppers and some other plants that I didn't recognize. A cutting of hay is brought in with the animals in the evening, and manure is carried out in the morning. By noon it is rather warm, and the smell of animals in the village is noticeable.

There are a number of small stores here, a large church, a big school, a soccer field, and a system of electric lights. Water is a problem, and it is obtained from streams and from cuts in the ground that serve as well-cisterns. Some of these cuts are deep and seem hazardous for animals and children. There is a large water trough in the lowest spot in the village, where a stream runs that is used by everyone for washing the vegetables before they go to the market in Puebla and Mexico City. Not all of the houses have toilets and there is no village sewer. If this were at a lower elevation, there would be problems of sanitation.

In a village pattern of settlement, there are often

in the area surrounding the nucleus zones that are dedicated to different kinds of production. Nearest the village are found garden plots if there is not room near the dwelling. Next there may be field crops. The pastures and land used less intensively, such as forest land, are usually furthest from the village. Where water is a problem, irrigation is 
reserved for the choice land near the village. This system of zones is one of the reasons that the village settlement pattern is often accompanied by fragmentation of holdings. Such a pattern causes further loss in efficiency as the farmer travels from plot to plot in his daily labors. 3

In an attempt to give needed protection as the harvest approaches, it is often the custom to erect a temporary shelter in the fields and have a member of the family there at all times. The following extract from my field notes gives an example of this:

(Cochabamba Valley, Bolivia, 1966) As we approached Malco Rancho, it was evident that the potato harvest was at its peak. Whole families were in the fields. The plots were so close together that it appeared as if the whole village had turned out, and there was a sense of festivity in the air. In the center of each of the plots was a temporary shelter on stilts. I was not sure if this was used for storage of the crop or what its purpose was; I was told that a member of the family stays there at every moment until the crop is completely harvested.

In contrast with the agricultural village, an isolated farmstead type of settlement is one in which the dwellings of the farmers are dispersed over the landscape, each on the land pertaining to the respective family. This pattern permits the farmers to be close to

${ }^{3}$ Smith, The Sociology of Rural Life, pp. 216-18. 
their work and at the same time to protect their crops and animals. It prevails in most parts of the United States; and in some parts of the Midwest a mile or so may separate the homes of neighbors. In areas of Europe and Latin America this pattern is also found, but it is not as common as it is in the United States. Costa Rica is exceptional in this regard, as most of the rural population lives on isolated farmsteads. In spite of the Laws of the Indies that were imposed by the Spanish Crown on the colonies, it was impossible to keep the people from going back to live on their land. This was due in great part to the fact that everyone was a land owner, and each cultivated his own land with only the help of his family. 4

Social isolation is the price that is paid for the increased efficiency of production in the isolated farmstead. This settlement pattern fosters reserve and formality in all social relationships. In extreme cases there is a lack of the social graces necessary for any kind of pleasant interchange. Cooperative community efforts are difficult in these cases, and such services as schools, roads, churches, and electric power are difficult to establish and maintain.

4 José Manuel Sal̦azar N., Tierras y Colonización en Costa Rica (San José: Universidad de Costa Rica, 1962), 
A third type of settlement pattern has occurred where special planning or geographical circumstances have fostered it. This can be classified as the line village. In this type of settlement, families live on the land that they work but, because of the arrangement of the farms, they also live close to their neighbors. French settlements in different parts of the world have shown this tendency. An important factor is a river, which serves as a ready built "road" near which all of the settlers build their dwellings. Farms of this type are narrow and deep, thus reducing the distance between the homes. 5

Realizing the advantages of this type of settlement pattern, those planning certain colonization projects have used it. They have found that it is efficient from a production standpoint and that it fosters necessary social interaction. Perhaps the outstanding example of this kind of planning can be seen in the "circular" line village found in Israel. The following extract from my field notes gives some of the outstanding characteristics of the Moshav Nahalal.

(Moshav Nahalal, Israel, July, 1965) The Freudenberg family live on one of the 75 farms that form the community. Their modern house faces a circular drive that is about three miles in circumference. It looks much

${ }^{5}$ Smith, The Sociology of Rural Life, pp. 213-16. 
like a city street with modern houses, some 50 yards from each other and all facing the center circle. Behind the houses are the barns and other outbuildings, with the kitchen garden directly behind the house. Beyond the barns are orchard trees and then the irrigated fields. At the very back of the farms are unirrigated lands that are planted to grain crops once a year. The farm is wedge-shaped, narrow at the front where the house is located and wide at the back of the farm. In the center circle are service facilities of all kinds -- schools, a synagogue, a community center, a swimming pool, a sports field, the water supply, the electrical plant, a fruit-packing plant, a milk-processing plant, a granary, a feed mill, a store, and a machinery repair center. Although the farms are individually owned and operated, the services are all run as a cooperative.

Using these three types as a standard of comparison, the contemporary settlement patterns of Nicaragua are li sted.

Contemporary Settlement Patterns in Nicaragua

A modified village pattern of settlement can be observed in many parts of Nicaragua. These villages are not as compact as those in the highlands of Mexico or Bolivia. There are no adobe walls to enclose the courtyards, perhaps because of a need for all of the possible breeze to dispel the heat. Other than this, the appearance is that of an agricultural village.

Los Rizos is an example of such a village. It is located approximately one hour from Managua in the San Rafael Sur area. There are approximately 90 homes in the 
village, and also a small store, a school, and a chapel. Each of the homes has an area that is used for growing some root crops, and there are a few chickens that belong to each family. Horses can be seen in the village at almost any time, and they sometimes are tied near the house and eat hay that has been cut for them. The horses are used for riding, and oxen are used for hauling. oxcarts are a common sight. The pasture lands are outside the village. Most of the people of this village work on cattle farms, or as field laborers on large farms nearby. Many of them also have small plantings of their own. In this same general area, there are four other villages much like this one. This general pattern has been observed around Masaya, León, and Chinandega. It is much the same for the whole Pacific region where the land is level and is cultivated. (See Figure 5.)

Upon close analysis, it is apparent that these villages are not true agricultural villages but clusters of dwellings belonging to agricultural laborers. It is true that many of those living in such locations as Los Rizos, Los Sanchez, and Los Gutierrez have small plots that they cultivate outside the living area, but the inhabitants of these caserios (village-like settlements) are essentially agricultural laborers. This is more akin to the settlement pattern of the hacienda or the plantation than the agricultural village. 


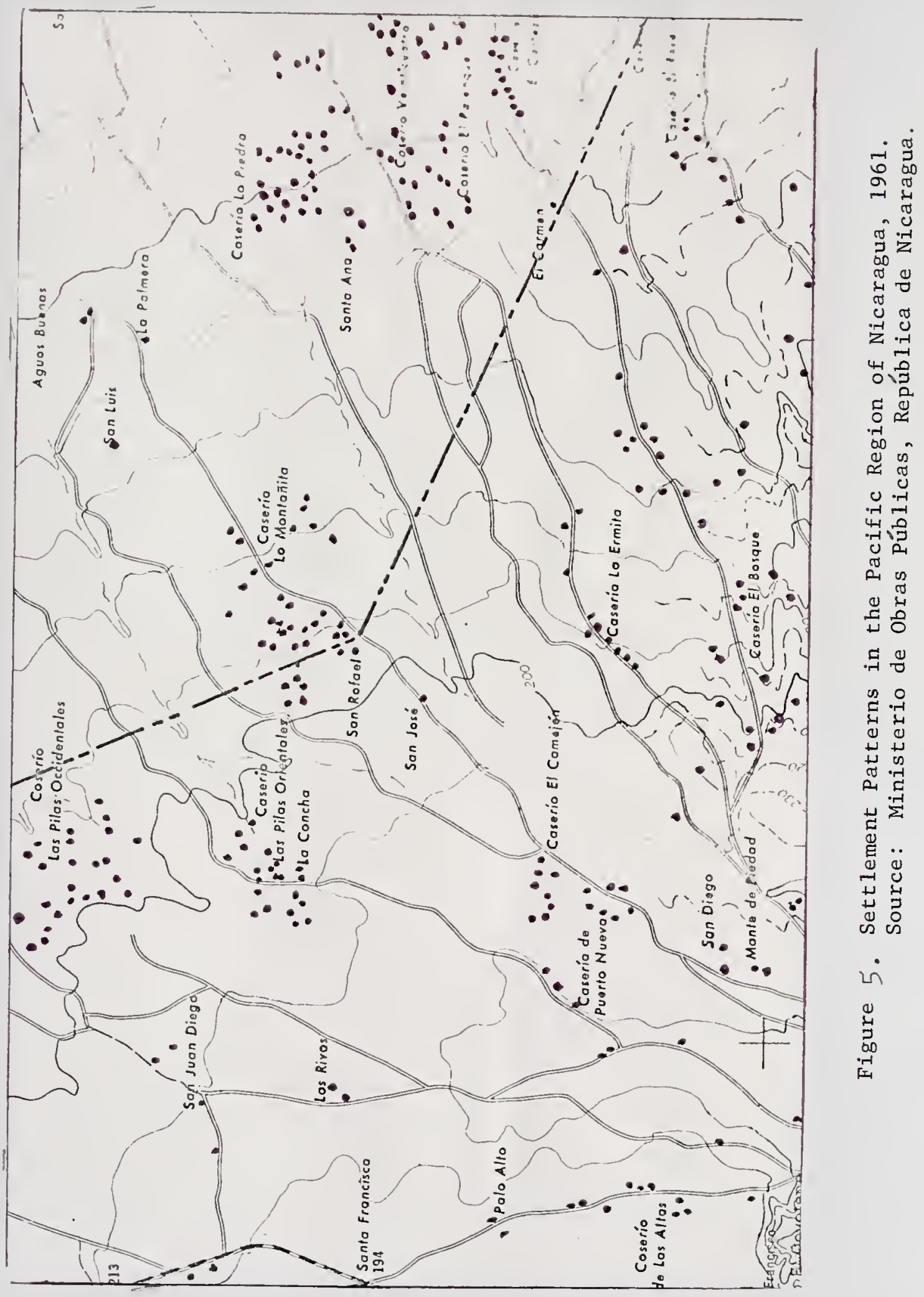


In contrast, the farm operator who is a full-time farmer generally lives on his land. For this reason the predominant settlement pattern in Nicaragua is the isolated farmstead. Away from the plantation and hacienda areas, the individual farmsteads can be seen dotted about in the countryside. (See Figure 6.) Most of the large land owners live in urban centers and visit their farms only from time to time. The manager or overseer of these large holdings lives on the land, as do at least part of the laborers. The fam renters also live on the land, although the rental contract may prohibit them from making any permanent constructions.

In the colonization projects sponsored by the National Agrarian Institute, provisions have been made for each family to live on its land. In some cases a modified line village plan has been used so that the essential services are available and social interaction is possible. From the literature, it appears that the primary consideration is to have each family live on its land. 6

${ }^{6}$ República de Nicaragua, Memoria (Managua: Instituto Agrario de Nicaragua, 1967). p. 7 . 


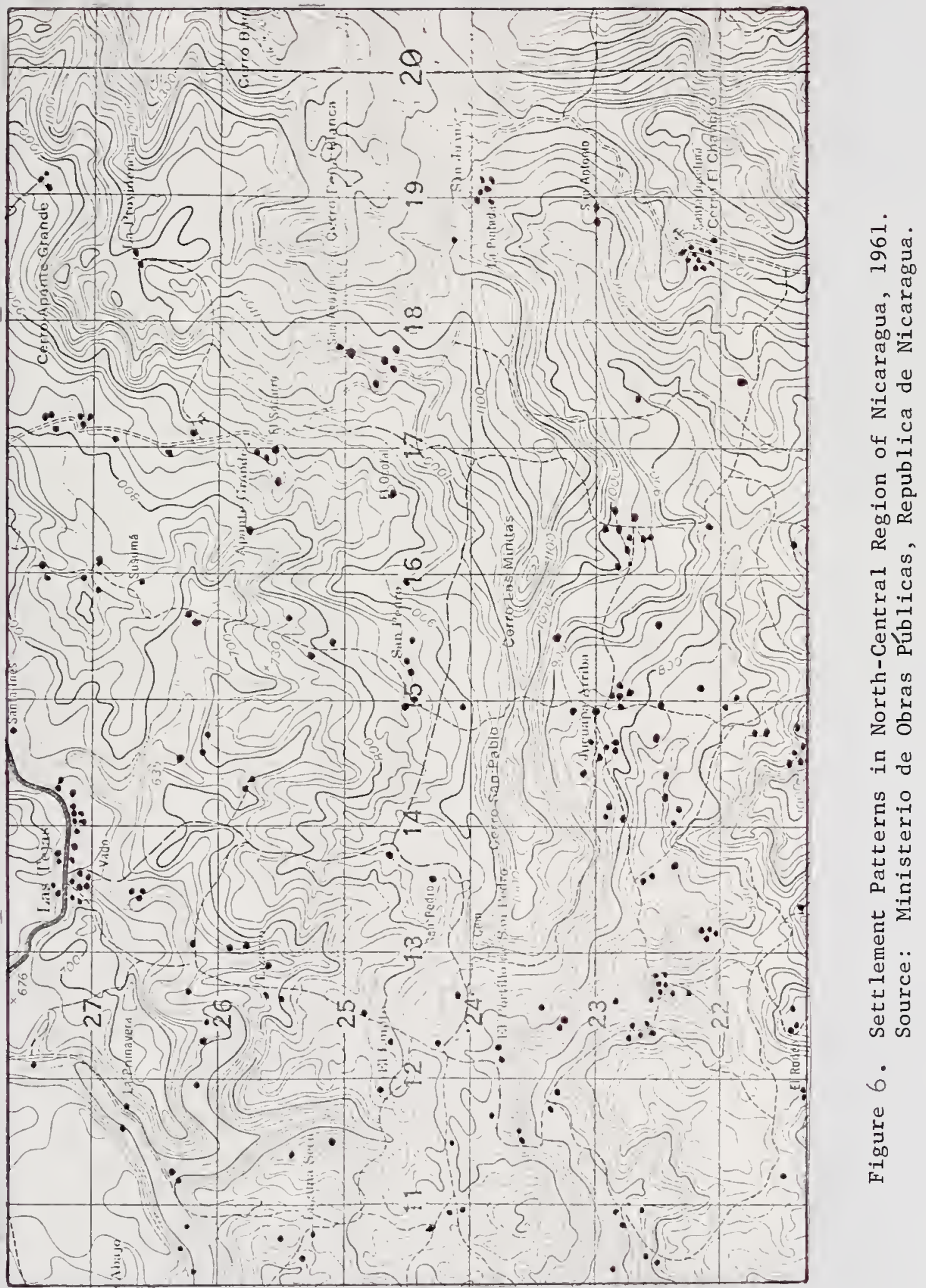


There are noticeable differences in the settlement patterns prevailing in the three geographical regions of Nicaragua. In the densely populated sections of the Pacific region, the village-like clusters are common. These are the same areas where the cattle haciendas, the cotton plantations, and the sugar cane plantations are found. In the hill and mountain areas the smaller farms are located, and the operators live on scattered farmsteads.

The North-Central region is more hilly and mountainous than the other regions, and there the scattered farmsteads prevail. Often the farm homes are in the numerous river valleys, so that contact is facilitated to some extent. In the cattle lands of Chontales, the cluster of hacienda laborers' homes gives a village-like appearance to the settlements. This is also true of the coffee plantations around Matagalpa.

The Atlantic region is a frontier area, and the rugged individual who stakes out his claim there expects to live apart from others. It has been found that most of those settling in this area came from mountainous areas of the North-Central region rather than from the densely 


\section{6}

populated Pacific region. 7 Many agricultural laborers have a desire to be on their own, but they have been accustomed to life in the caserios and would find living in isolation difficult. Closer to the Atlantic coast, the isolation is less. In this area are found many of Jamaican and Mesquito backgrounds. ${ }^{8}$ The navigable rivers and coastal lagoons serve as means of transportation and communication and some examples of line-village types of settlement can be seen. Settlement has gone on rapidly along the new Rama Road that connects the Atlantic to the rest of the western part of the Republic. (See Figure 7.) So far, no directed settlement has been carried out there, but the National Agrarian Institute has planned major colonization projects for this area. 9

The variations to be noted in settlement patterns in Nicaragua give further indications of how custom prevails in man's relation to the land. The question has often been asked: Why do the poverty-stricken agricultural laborers of the Pacific region continue to live in

7 República de Nicaragua, Censos Nacionales 1963: Población Volumen IV (Managua: Dirección General de Estadistica y Censos, 1967), pp. 25-26.

8 The Mesquito Indians maintained a separate kingdom for many years which included almost one-half of the distritos of Zelaya. This kingdom was backed by British interests and there was a free interchange with Jamaica during this period.

${ }^{9}$ República de Nicaragua, Memoria. 


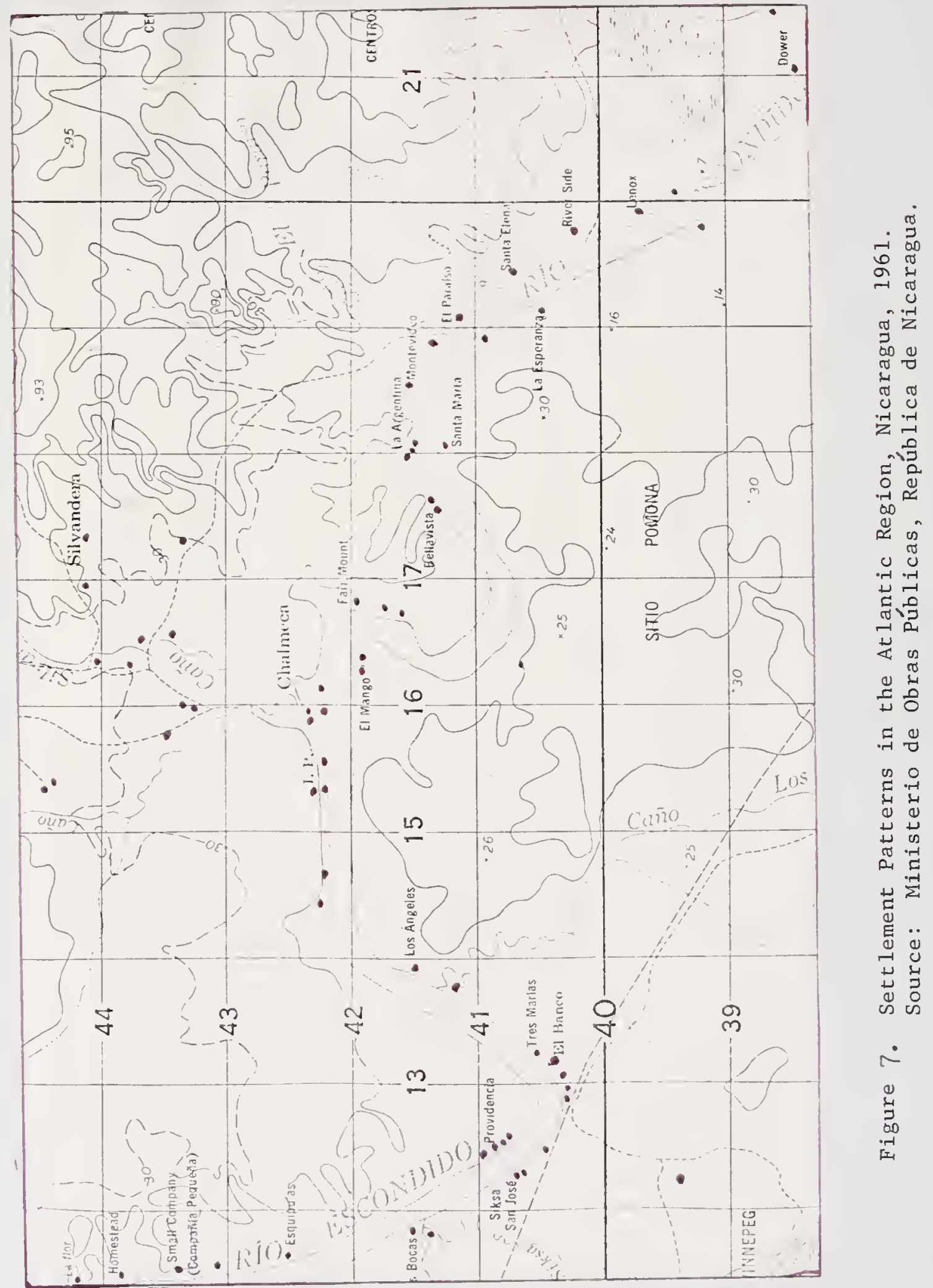


that area when there are vacant fertile lands waiting to be claimed in the Atlantic region? Recently, as I was talking to a man who was contemplating such a move, he expressed the reason very clearly. He said, "A man does not like to move away from his people and his place." This man was formerly an agricultural laborer but, being of an enterprising nature, he is now renting and operating 50 manzanas of good cotton land in the Pacific region. The increasing rate of rent is squeezing him out, but he prefers economic loss to social isolation.

\section{Factors Responsible for Present-Day Settlement Patterns}

The form of settlement is a cultural pattern that is borrowed or transmitted rather than invented. Village and scattered farmsteads patterns are both found in the cultural heritage of Nicaragua. Moreover, geographical features, land use, the time of settlement, the tenure relationships, the size of holdings, and the years of political upheaval have all contributed to the contemporary situation.

Isolated farmsteads seldom arise where large proportions of the land are owned and operated by a few people. Usually, it is more convenient to have the laborers living in a central location instead of being scattered over the land. In Nicaragua, for those who sought to escape these 
conditions, the alternative was to stake out a claim on uninhabited land and physically occupy it hoping that some day physical occupation could be backed by legal recognition of ownership. Many have persevered, and isolated farmsteads prevail today; yet the cost of isolation and lack of protection during political strife have forced many to go back to the safety of numbers.

Results of Present-Day Settlement Patterns

There are a number of characteristics to be noted in those areas where isolated settlement patterns prevail. Migration to these areas is increasing, and the proportion of males to females is greater than it is in the more populous areas. School facilities are inadequate. Illiteracy is high and school attendance is low where there are isolated settlement patterns. Levels of living are low, as can be seen in the high proportions of homes without water, without sanitary toilets of any kind; there are also few radios. The fertility index is generally high in these areas, although the proportion of legal marriages is low.

In the extreme cases of isolated settlement, such as the Atlantic region, the distance from farm to farm and to the nearest trade center makes it impracticable for the government to provide social services. Often these services come only when community pressure is applied, but 
there is little feeling of community even to request government help. This region also has the highest proportion of land occupied without legal title.

There are further aspects that cannot be measured in statistics. The social graces that are considered minimum equipment for the twentieth century are lacking in families growing up in these isolated situations. A good example of this was provided me by a school teacher from the departamento of Nueva Segovia. He said that it is common in many areas for the children to hide when a stranger comes to the farm. He has had trouble as a teacher getting the children to come to school even when schools are provided. He has found that to visit a family in an isolated home he must pick the time of day when the farmer is in the house if he is to find anyone at home. It must be noted that the problems of health, education, and general levels of living are not completely dependent on settlement patterns. The concentration of the land and the inadequate distribution of the property rights to the land have also been shown to affect the levels of living.

Evolution and Trends

Pre-Columbian settlement patterns in Nicaragua were not uniform. In the Pacific, there were established agricultural villages. From the villages, the farmers and their 
families went out to the surrounding fields, as was the custom in all of the areas of Central America where corn was king. 10 This pattern did not conflict with the desires of the spanish conquerors. It was easier to control the labor force if they were all together, and it was easier to use the agricultural land if the people were not living on it. Also, the Laws of the Indies prescribed the agricultural village as the settlement pattern that should prevail.

In the Atlantic, pre-Columbian agriculture and settlement patterns were different. Rather than sedentary seed growers, the Indian tribes were migratory hunters and gatherers. ${ }^{11}$ The tribal organization was not as formal and there were few established villages. Individual families were freer to move about on their own in order to search for better food sources. As the land and labor of the Indians were portioned out to the conquering Spaniards, the only escape was to the east. Even the Indians who were accustomed to living in close tribal unity found isolation a better alternative than slavery and death. Nor did all the Spaniards get large land grants, and

${ }^{10}$ Carl 0. Sauer, Agricultural Origins and Dispersals (New York: The American Geographical Society, 1952), pp. 40-60.

${ }^{11}$ José D. Gamez, Historia de Nicaragua (Managua: El Pais, 1889), p. 50 . 
some of those who got no grants preferred independence in isolation to dependence on a large hacienda. The net result was that the hills and mountain areas became areas of isolated settlement, and the level areas of the Pacific region came to be occupied by the plantations and haciendas where the laborers lived in caserios.

The transition from the predominance of the agricultural village to the present scattered farmsteads type of settlement can be seen in a reference made by squier in his travels in 1847. He observed that most of the people lived in towns and went out daily to labor in the fields. He noted that the forest was dotted with small clearings where the people had their plantings. It is likely that these observations were made in relation to the small plots in the hills for the level areas of the Pacific region were occupied by the plantations and haciendas long before this time. He also noted that a general state of banditry and violence prevailed in the isolated country areas at that time. ${ }^{12}$

The push into the unoccupied lands has taken place at an increasing rate in recent years. The growth of the rural population between 1950 and 1963 in the North-Central and Atlantic regions was 41.6 per cent and 34.5 per cent, respectively, as compared to 24.5 per cent in the Pacific

12E. G. Squier, The States of Central America (New York: Harper and Brothers, 1858), $\frac{1}{364 .}$ 
region. ${ }^{13}$ As indicated above in these areas the scattered farmsteads type of settiement prevails.

Summary and Conclusions

Most Nicaraguan farm families live on their land in scattered farmsteads type of settlement. There are many village-like clusters in the rural areas but, upon close examination, the majority of the residents of these are found to be farm laborers and not farm operators. The owners of the large farms are city dwellers.

The village-like clusters are most common in the Pacific region where the proportions of minifundia and latifundia are high. In the North-Central region, most of the families live on their farmsteads. In this area, there are few laborers so that the village-like clusters are not common. In the Atlantic region, most of the farm families live on widely separated farms.

A number of factors account for the present settlement pattern. The village-like clusters are part of the heritage from the pre-Columbian culture as well as from the Spanish colonizers. The scattered farmsteads were

13 República de Nicaragua, Censos Nacionales 1963: Población Volumen I (Managua: Direccion General de Estadistica y Censōs, 1964), pp. xvi-xviii. 
produced in part by a desire of the laborers to escape servitude on the plantation or hacienda. Other factors such as geographical features, type of agriculture, and political instability have also been important.

A consequence of the scattered farmstead type of settlement is a lack of social interaction and the scarcity of community institutions and facilities such as schools, roads, and churches. It also probably has done much to prevent the development of effective local self-government. The youth that grow up in these areas have little opportunity for preparation for the future.

Due to spontaneous and planned colonization, the number of people living on their land is increasing in the eastern portion of Nicaragua. There, a few line-village type of settlements are developing, but most of them are made up of single farmsteads. In the Atlantic region, new settlements are rather chaotic, although the government is trying to promote planned colonies and the ways and means of establishing clear titles to the land. 


\section{CHAPTER VII}

\section{SYSTEMS OF AGRICULTURE}

The concept, system of agriculture, is an analytical device that is helpful in the observation of the intricate activities that take place in the production process. A system of agriculture has been defined as "that integrated set of ideas, cultural traits, skills, techniques, practices, prejudices and habits employed by the members of a given society for extracting a living from the soil."I

The term "system" aptly applies in discussing this aspect of man-land relations because there are many elements involved, and these elements are with one another as parts of a functioning whole. Anyone who has lived and worked on a farm realizes how closely the production process is interrelated and how it shapes all of the family's activities, as well as those of the community. The daily care of animals means a routine schedule around which other activities are planned. During the season of the harvest, all other activities are adjusted to fit the special

IT. Lynn Smith, The Sociology of Rural Life (New York: Harper and Brothers, 1953), p. 324. 
situation. All of the jobs necessary to make each of the different enterprises successful are woven into a complex pattern. The result is a balance of expenditure of time, energy, materials, and equipment.

Systems of agriculture are more than mere patterns of farm management dealing with the different activities of the production process. Much more important in the study of man-land relations are the aspects that make it truly a socio-cultural system. Agriculture is a way of life in which all of the cultural heritage is applied at every moment as the individual works with the land and with his fellow men in achieving the desired production. Good examples of the close interrelation of the elements of an agricultural system can be seen where subsistence agriculture predominates. All of the traditional ways of doing things have a quality of ritual that is not easily changed. The time and manner of preparing the soil, the preparation of the seed to assure germination, the ways in which the planting is done, and so on until the crop is safely stored -- everything is done with fear of a misstep that will result in a poor crop. The system includes all the activities in the field as well as the festivals and religious rites of the community. What the producer is and does is related to the production process, and any change is likely to bring disaster. The following extract from my field notes illustrates this point. 
(Oriente, Cuba, 1956) In the farmers' meeting tonight the leaf-cutting ant was discussed. It has been extremely costly this year and has destroyed a number of young citrus plantings. One farmer spoke, suggesting that the only remedy that really works is to take several ants, put them in a paper bag, swing the bag in a circle over your head, at the same time repeat seven "Ave Marías," then crush the bag and throw it out of the field saying "to the devil." It was interesting to note that no one disagreed with this remedy, although one farmer suggested that DDT had also worked.

It is evident that this practice was part of an intricate pattern of beliefs, values, habits, traditions, and accepted customs of the community that could not be changed unless the new practice could be seen to fit.

All of this suggests that an analysis of agricultural production based on the concept of systems of agriculture can be extremely fruitful. If agricultural production must be increased to win the battle with hunger and if each production practice is merely one part of a systematic way of life that cannot be changed separately, then it follows that the attempt to introduce separate practices by themselves will have little success.

Going beyond the point of hunger, if the levels of living are to be raised for the rural population and in turn for the whole country, the system-of-agriculture approach has further meaning. T. Lynn Smith has suggested that the system of agriculture that is used by a people has more to do with determining the level of living than 
any of the other factors that have been suggested as determinants. ${ }^{2}$ Even those natural resources which we consider to be desirable are of little utility until the values and technology of a society make them useful. The six basic agricultural systems as developed and described by Smith are used in this study. These are: (I) river bank plantings, (2) fire agriculture or felling and burning, (3) hoe culture, (4) elementary plow culture, (5) advanced plow culture, and (6) mechanized farming. 3

Contemporary Systems of Agriculture in Nicaragua

Nicaragua is a land of contrasts in many respects and particularly in the methods that are used in extracting products from the soil. One can observe the most modern equipment and techniques used in the production of cotton and, on a neighboring hill-side, the smoke rising as the subsistence farmer burns off the vegetation to prepare for his small planting of corn. The latter practice pre-dates even the crudest hoe or plow in man's experience as a cultivator of the soil. The six basic systems of agriculture are presented here, along with indications of the extent to which they are used in Nicaragua.

$$
\begin{aligned}
& { }^{2} \text { Ibid., p. } 325 . \\
& 3 \text { Ibid., p. } 330 .
\end{aligned}
$$


River Bank Planting

This is but a step above mere collecting as a means of obtaining products from the soil. The system is characterized by the use, as a seed bed, of the soft soil left on the banks of a receding stream. The beast of burden is the human being, and the tools are the feet and hands of the woman who does the planting.

There is little evidence that this system of agriculture is relied upon to any great extent in Nicaragua. small plots of corn and other crops are sometimes planted along the rivers and streams in areas that are below the high water line; when this occurs, it is usually to take advantage of good soil and to be near water in case simple irrigation is needed. Often the planting is close enough to the water level for the roots to go down and obtain enough moisture even in the driest part of the year. Simple tools, such as the hoe and machete (long knife), are used in weed control. The products are taken from the plots on pack horses if the harvest is large enough, but usually the planter himself is the means of transportation. No figures are available to indicate the extent of crops grown in this manner. From personal observation, I would judge that a very small proportion of Nicaraguan crops come from this type of production. 
Fire Agriculture or Felling and Burning

As a system, fire agriculture is much like river bank planting but here it is fire instead of water that prepares the seed bed. First, the trees and brush are cut and left to dry. When the materials are dry enough and the weather suitable, it is burned leaving a soft, pliable and ash-covered seed bed. Few, if any, tools are used. A digging stick is often employed to make the hole for the seeds but, if the soil is soft enough, the human foot serves the purpose. A negligible amount of effort is required for weed or insect control, for the fire leaves little insect or plant life to compete with the crop. The harvest is usually large enough to be carried off on the back of an animal, on a sled arrangement, or even on a simple wheeled vehicle.

This practice is extremely depleting of soil reserves. Particularly in tropical areas, the most important agricultural factor in the soil is the amount of organic matter, which comes from decayed plant life. If the organic matter is burned, it never reaches the soil and, further, the organic matter in the soil itself is burned. Fire agriculture has been modified to a rotation system of burning, where the land is allowed to go back to second-growth vegetation from time to time so that the organic matter is not completely burned out. In any event, 
production gradually declines over the years with this system of agriculture.

In Nicaragua, fire agriculture is used extensively. Just prior to spring planting, usually in the month of April, smoke can be seen on the horizon in all directions. This could be compared to spring plowing where other systems of agriculture are used. Many arguments are used to defend the practice of burning. Some say that they have always done it that way, and that it is the customary way to raise crops. Usually, there is agreement that it does make the soil "tired" after a few years and it must be left to "rest." Some planters report that they have tried planting by other methods, and that such methods resulted in smaller crops, even though they prepared the seed bed and controlled the weeds and insects. They are absolutely correct in this observation, and it is one that anyone attempting to change the practice or the system should take into account. Volcanic soils may be extremely acid, even beyond the point of tolerance for many crops such as corn. A corn plant can grow perfectly in such soils, but, when it comes time to form grain, phosphorus is needed in rather large quantities. This element becomes insoluble and unusable when the soil is even slightly acid, even though it may be abundantly present in the soil. The ashes left from burning the dried brush and plants neutralize the soil acidity, thus freeing the phosphorus and 
giving higher grain production. Naturally, the se are only short-range increases, for once the phosphorus is used up or leached off, the soil will produce a very small crop even with ashes to help.

The most important reason for the extensive use of fire agriculture is that it fits into a total system of production and rural life. To change from burning to another practice would mean changing many things, including the orderly way that the agricultural calendar is arranged according to custom. There are alternatives, such as the planting of velvet beans, which completely choke out everything else, can easily be chopped down, decay quickly so that a mulch is formed for the new seed bed, and add organic matter and needed chemical elements to the soil. Yet this practice has been tried and abandoned because it does not fit the system.

As with river bank plantings, there is no way of calculating the amount of production that comes from the system of fire agriculture. From personal observation, I would say that most of the grains grown on the small- and medium-sized holdings are products of this system. This is especially true in the North-Central and Atlantic regions because of the hilly land that does not lend itself to plowing. It is commonly referred to as desmonte $\underline{y}$ quema (felling and burning). A stick (espeque) is used for planting in most cases, although a hoe is sometimes 
used. Particularly in the hilly land, the crop is hauled from the field in a cruzeta (wooden cross frame) on the back of a horse.

\section{Hoe Culture}

Hoe culture as a system of agriculture introduces the practice of soil preparation by means of man-made tools. In the most elementary form of this system, a crooked stick is used to prepare the soil. The stick is selected and prepared to do the job in the best manner possible. Today a metal blade is attached to the stick to make it into a hoe. Other tools such as a sickle or machete are used in the harvest. Animal power is used for transportation, although the crops are often carried on the back of the farmer. Fertilization and irrigation may be part of this system. The hoe also allows for weed control during the growing period, which is not possible with river bank plantings and fire agriculture. Even with as simple a tool as the hoe, considerable control of the environment is possible.

Because of the extensive use of fire agriculture, hoe culture as such is not as common in Nicaragua. The hoe is often used, but it is used in conjunction with burning. After the land has been burned over, it is left a while before it is further conditioned by the hoe. In most of the Republic, the macana is used instead of the 
hoe. This implement has a longer handle and is not as wide as the hoe. It is open-faced like a shovel so that it is pushed instead of pulled. Particularly in corn culture, the young plants are cultivated with the hoe or macana to prevent any competition from weeds.

Where coffee is grown on the high hillsides, hoe culture is common. Fire agriculture is impossible because of the multi-season life of the coffee plantings, yet some kind of cultivation is needed periodically. It is not possible to use animals and plows, since the terrain is too steep. A hoe, a macana, a simple shovel, or a special knife are the only implements that give satisfactory results. Coffee is also a crop that is fertilized. In some of the larger plantations, streams have been diverted for irrigation purposes. The coffee is carried by the pickers to be measured at the edge of the field and is then transported by pack horses or in oxcarts to the plants where it is processed.

It is not possible to give any exact statistics on the proportion of Nicaraguan production that comes from hoe culture. From observation I would judge that it is less important than fire agriculture. It is found as a predominant system in coffee farming and this occupies only 
2.6 per cent of the farm land in the Republic although it does represent approximately 14 per cent of all crop land. 4

\section{Rudimentary Plow Culture}

The first use of draft animals was in the preparation of seed beds, and this was a real breakthrough in the evolution of the methods of producing food. Rudimentary plow culture represents the beginning stage of man's attempts to break the soil with a crude, pointed instrument that is pulled by a large four-footed animal. In most cases, this animal is the ox, and usually the plow itself is little more than a pointed piece of wood that roots the soil instead of turning it. There are other instruments besides the plow in this system: the soil is further broken up and leveled with a sled-type of drag, the harvesting is done with a knife or sickle, threshing is done by beating, and the crop is transported with the help of animals.

Rudimentary plow culture is common in Nicaragua. Particularly on the small- and medium-sized farms, oxen are to be seen working in all of the many operations of agricultural production. (See Figure 8.) This is particularly true in the Pacific region where most of the

${ }^{4}$ República de Nicaragua, Censos Nacionales 1963: Agropecuario (Managua: Dirección General de Estadistica yCensos, 1966), pp. xx-xxiii. 

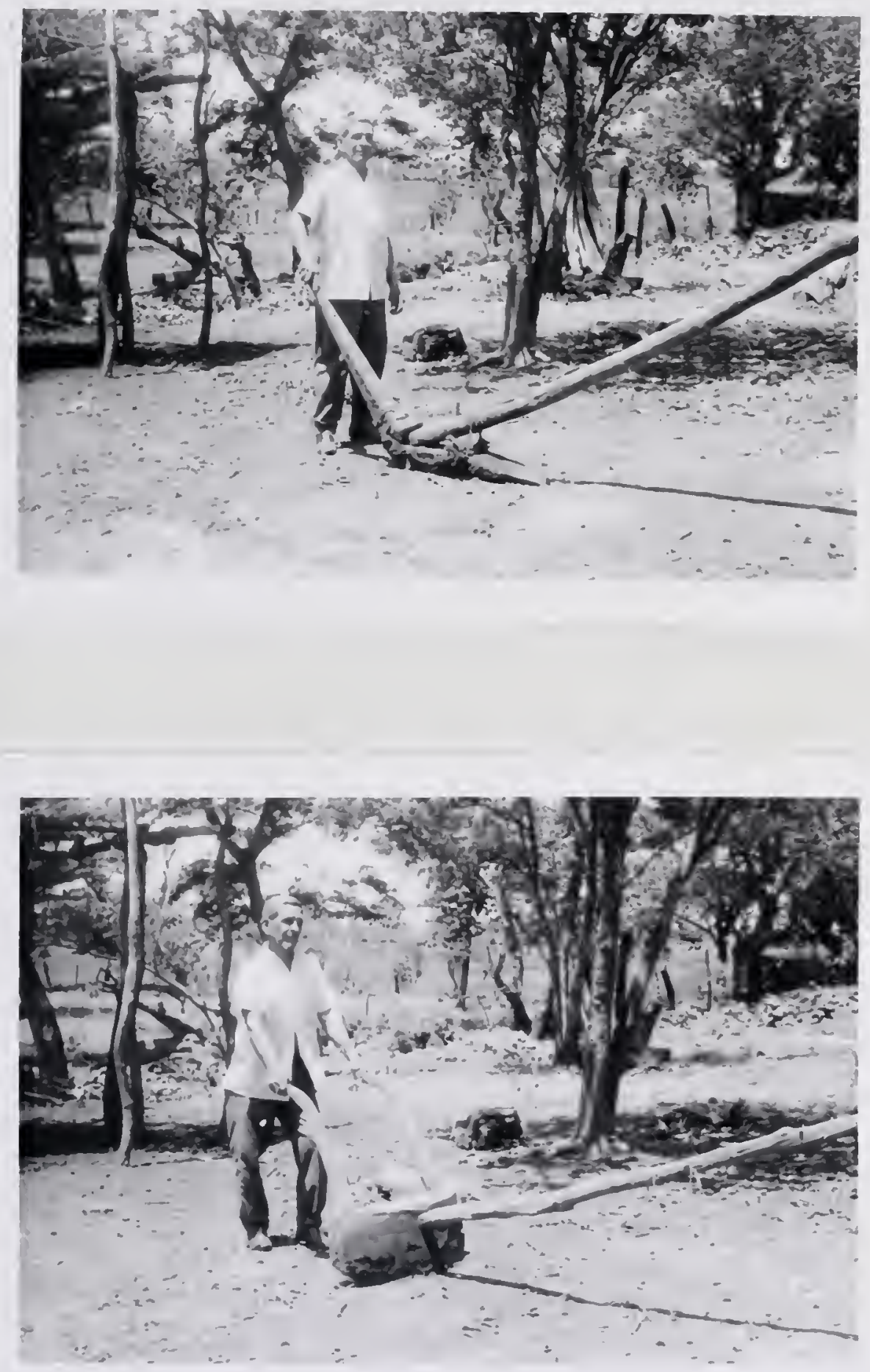

Figure 8. Agricultural equipment used in Nicaragua. Upper: native plow for use with oxen. Lower: a hiller also pulled by oxen. 
terrain is not rugged and the land is freer of stumps than the other regions. Of the 55,909 oxen (bueyes) enumerated in the 1963 census, 31,402 were in the Pacific zone. There were 22,912 in the North-Central region and only 1,595 in the Atlantic region.

The oxen are hitched with a head-yoke instead of the neck-yoke. A good set of horns is an asset, for it provides a secure place to lash the yoke. From the yoke, a long pole (timón) goes back to a simple plow that has but one handle and a wooden point covered with metal in the shape of a long cone. The plow is pulled through the ground by sheer force, and there is little adjustment possible that can improve the efficiency. If the ground is hard, a stone may be lashed to the plow for deeper penetration. The same plow is used as a harrow, and the land may have to be gone over a number of times. The plow is also used to make the furrow for planting and later for weed control in a row crop such as corn.

The spike-point type of plow is being replaced in some areas by one with a strong moldboard that works much better in sod. The adjustments are few and it seems to give good results. Where this turning plow is used, other implements are needed, such as a harrow and a cultivator, because a plow with a moldboard does not double as a drag and a cultivator as does the spike-pointed plow. There 
are no data available on the number or types of plows now in use in Nicaragua.

The oxcart is even more conspicuous than the plow. As one travels in the rural areas, and even on the highways, oxen can be seen pulling the two-wheel carts with any and every kind of load imaginable. The speed of the oxcart can be judged by the fact that the driver usually is walking and has no trouble keeping up with the vehicle. The oxen are guided with a long stick that is also used as a prod. There are still many carts with solid wooden wheels covered with steel rims, although rubber-tired wheels are coming into use.

In Nicaragua, except on the large farms, the grain is harvested with the machete. The machete is one instrument that is never lacking and is probably the first tool that the farmer buys. In the case of upland rice, which is common in most areas of the country, the stalks of grain are dried in the field and then threshed. A threshing floor is prepared by placing canvas on the ground and a vertical wooden platform at one end. Small packets of stalks are beaten against the platform, and the grain falls on the canvas. The flail is not used. Later, the worker cleans the grain by scooping it up and dumping it from as high as he can reach. If the wind is not strong enough to blow away the chaff, then it must be fanned as it falls. In wet weather and also when grain is stored for home 
consumption, it is not threshed but stored in bundles in the house or other shelter. The stalks are cut off, leaving only the heads; these are hung from the rafters. Corn is also stored this way, and the best place for such storage is the large open kitchens, where the smoke serves to dry and preserve the grain.

Another familiar sight in the country homes is the large mortar and pestle (pilón). This equipment is closely related to rice growing or, better, rice consumption. The rice must be hulled before it is usable, and the pilon is used for this purpose.

Advanced Plow Culture

Efficiency is the outstanding characteristic in the system of agriculture denominated as advanced plow culture. This system has developed where there has been a constant effort to improve the efficiency in the use of land, labor, and energy. The ox is replaced by the horse because the horse is faster and smoother in gait; the cumbersome neck hitch and heavy wooden center tree are replaced by the collar and a light-weight system of hitches that can balance each animal of the team for the job. The rooting plow is replaced by the turning plow, which has adjustments for depth and soil differences. Each operation, from seed bed preparation to storage of the crop, is made more efficient by labor-saving devices. Such machines as the sulky plow, the spring-toothed and spike-toothed 
harrows, the drill, the walking and riding cultivators, the mowing machine, the hay rake, the hay loader, the reaper, the threshing machine, and the important fourwheeled wagon are all part of the advanced plow culture. Even special breeds of horses are developed to add more power to farm operations.

We should make one observation before further discussing advanced plow culture in Nicaragua. Efficiency in agriculture takes place only where there is incentive for it. Advanced plow culture is closely related to the familysized farm. As indicated in Chapter IV, it is here that the combination of capital, management, and labor in the person of the farm operator gives the highest incentive for efficiency. Each task that is performed is analyzed by the performer, and some truly ingenious inventions have come out of the process. When invention itself becomes part of a cultural pattern, it is not strange to see the farmer's contributions to technology, such as steel being used to make a plow scour on prairie soil, or a sickle-bar mower replace hand cutting of hay and later become a grain reaper, or a corn planter, mounted on wheels, doing more work in an hour than one man can do in a whole day. It is not by chance that the highest development of advanced plow culture has taken place where the family-sized farm prevails. 
Advanced plow culture is not common in Nicaragua. This is not to say, however, that agriculture has not advanced beyond the stage of rudimentary plow culture, but that the conditions in Nicaragua have not been conducive to the widespread development of efficiency in the use of land, labor, and energy. On the larger farms, though, there has been a leap from rudimentary plow culture to mechanized agriculture. A good example of this can be seen in the jump from the oxcart to the jeep and from the ox-drawn plow to the tractor plow.

Horses are common in Nicaragua, as are mules and donkeys. For the most part, these are not used as draft animals but for riding and packing. The 1963 census accounts for 174,768 horses, 43,627 mules, and 6,726 donkeys (asses). The greatest numbers of all three animals are found in the North-Central region, where trails are more common than roads or lanes. 5

\section{Mechanized Agriculture}

Mechanized agriculture is characterized by tractor power. There is hardly a person in Nicaragua today who has not seen a tractor at work. All of the large farms in the Pacific region use tractor power unless they are

\footnotetext{
5 Ibid., p. xxxvii.
} 
dedicated exclusively to cattle raising on native grass. Tractors are not as common in the North-Central and Atlantic regions because of the terrain, although the lumbering operations have introduced them to even the more remote areas. The latest data available (1967) account for 2,409 tractors. 6 The distribution of tractors, as well as other components of mechanized agriculture, can be seen in Table 15 .

Mechanization has been applied to all phases of cotton production except harvesting, and even this application is now beginning. A few enterprising young men are buying equipment and hiring it out for custom plowing, cultivating, spraying, and hauling at harvest time. The next step is for them to rent land and put in the crop for themselves. Mechanization has gone to the point of widespread use of small planes for spraying and dusting.

In other large-scale enterprises such as sugarcane production, mechanization is applied to all stages except harvesting. Coffee producers have applied various levels of mechanization but more at the stage of processing than in the field. The growing of corn, rice, and beans is not

${ }^{6}$ República de Nicaragua, Informe Anual (Managua: Banco Central de Nicaragua, 1967), p. 104. 


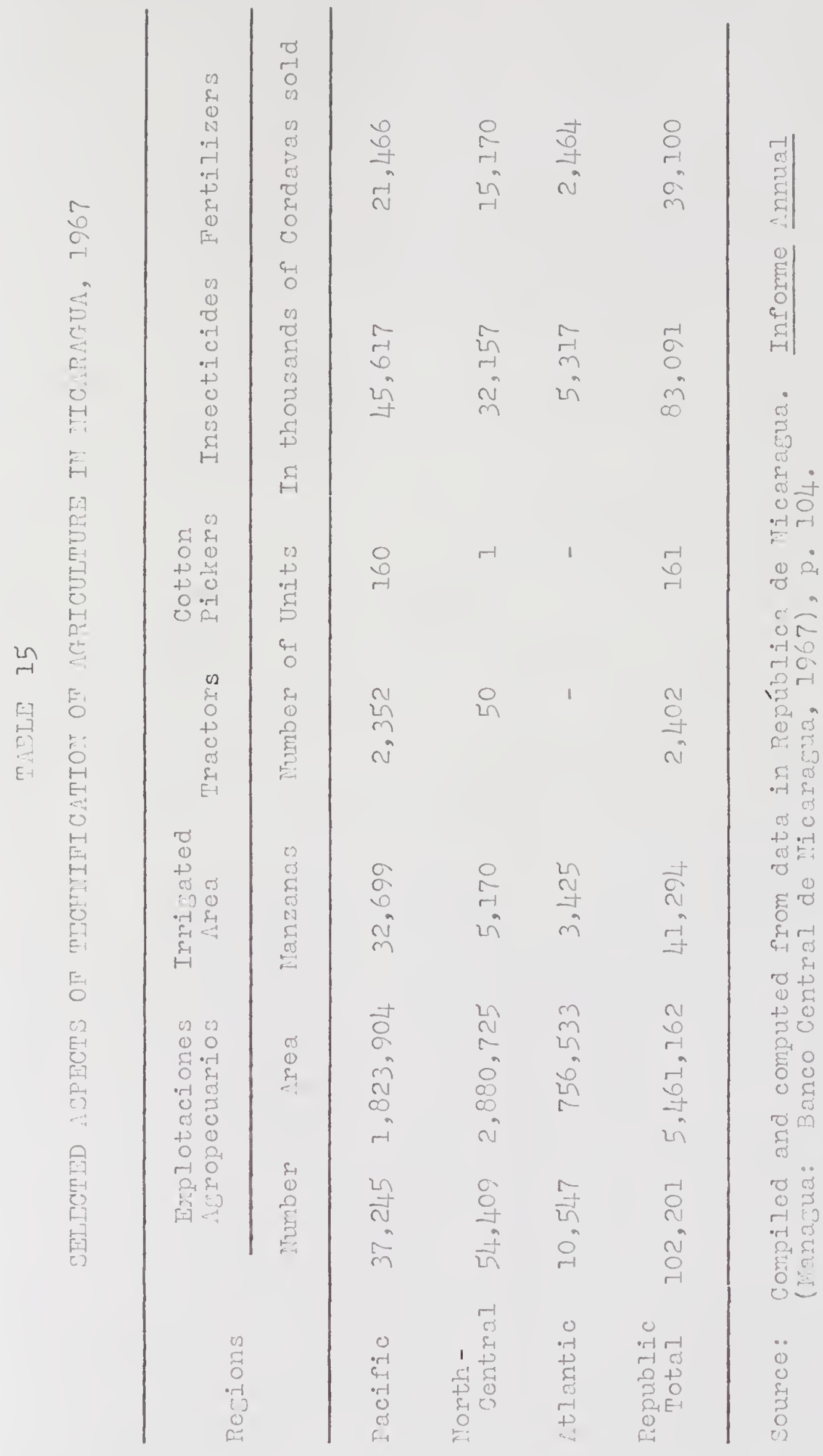


highly mechanized except where these crops are grown on a large scale.

An interesting situation is developing in some areas because of the availability of custom plowing and other services. Some small farm operators find it to their advantage to hire someone to plow their land instead of keeping oxen of their own. There is diversity of opinion as to whether the outcome is the same. Some feel that the land is not prepared as well, and others have frankly confessed that many other parts of the system are changed when they get rid of the oxen.

Further indications of the degree of mechanization of agriculture can be seen in the products and techniques used in Nicaraguan agriculture. (See Table 15.) Considerable amounts of chemical fertilizers, insecticides, fungicides, and herbicides are being used. Also sprinkler irrigation is being used on a large scale in some areas to offset the lengthy dry season.

In summary, the prevailing systems of agriculture in Nicaragua are: (1) fire agriculture, practiced as such in much of the North-Central and Atlantic regions; (2) rudimentary plow culture, characteristic of the smaller farms in the Pacific region and, where the terrain permits, in the North-Central region; and (3) mechanized agriculture, practiced on the large farms in the Pacific region and to some extent in the North-Central region. Burning is also 
common in pasture renovation, and in getting rid of the residue of former crops in both rudimentary plow culture and in mechanized agriculture. Advanced plow culture is conspicuous by its absence, due largely to the lack of family-sized farms.

\section{Reasons for Present Systems}

The level of technology applied to the efforts of extracting products from the soil is closely related to values and attitudes. These, in turn, are the result of cultural traditions that persist through many generations. For example, the attitude toward work, and particularly field work, is one of disdain. This has been present in Nicaragua since the Spaniards first came as conquerors and masters but not as tillers of the soil. The desired relationship to the land is that of owner or operator, but not as a laborer.

Another observable set of values or attitudes is that which concerns education. Education is not generally regarded as a means of improving agricultural techniques. Rural people have a high regard for education, but it is seen as a means of leaving agriculture instead of improving it. A farmer who wishes for his son to continue on the farm will consider that his training should be done on the farm. The cultural pattern of education in Nicaragua involves preparation for urban life but not 
for a better life in the country. Except in special cases, the teachers are oriented toward urban Iife and values. These attitudes, as part of the cultural heritage of the present inhabitants constitute a major reason for the existence of the present system of agriculture in Nicaragua .

The Indians were using fire agriculture and a simple version of the macana long before the arrival of the Spaniards. The conquerors brought with them hoe culture and rudimentary plow culture. There have been no largescale transplantations of farmers with a cultural background of advanced plow culture in Nicaragua as there were in North America. Without these farmers to introduce and perpetuate this advanced system, it would take many centuries and rather special conditions for it to evolve if it developed at all.

There are also some conditions and special situations that are responsible for maintaining the prevailing systems of agriculture in Nicaragua: the lack of familysized farms in which the entrepreneurial factor operates to increase efficiency and improve techniques; the lack of an effective land tax that puts a premium on intensive use of the land; the internal strife during the history of the Republic in which plunder and destruction have limited orderly progress; the lack of adequate credit facilities for the small producer; the lack of market security 
resulting in minimum capital input in production; the insecurity of tenure which fosters resource mining instead of resource development; and the lack of farm-to-market roads which will allow quick delivery of perishable products to the consumer. All of these elements contribute to the insecurity of attempting new techniques. At the same time, the security of old and tried ways of doing things, of continuing the many activities and practices that "all fit together," make change and innovation difficult.

In spite of this, agriculture in the Pacific region has changed more in the last ten years than it did in the previous century. With the commercialization of cotton production, many changes have been noted. Supervised credit has been made available by international buyers; thus a guaranteed income has been assured. The production has been guided by expert technicians whose recommendations must be followed as a prerequisite to the receiving of credit. Marginal producers are being squeezed out by the competition for the land on the rental market. The subsistence plots have been eliminated as a result of this competition and of the lack of rights to the land. In the areas of cotton production, the choices have been limited to adopting the new mechanized system of agriculture or leaving. The large owners have adopted the 
system or rented to those who did; the small land owners have adopted the system and rented more land or left the area.

Key people in this new system are the tractor drivers and operators of special machinery. They are much different from the traditional agricultural worker and have skills that surpass those of their employers. Instead of being bound to the inefficient routine of the field worker, they are oriented toward efficiency, the learning of new skills and the improvement of the present ones. It is not strange that they often have their own equipment and rent land to become farm operators themselves. They are younger men who are oriented toward mechanics and are given as much backing by their fathers as economic circumstances permit.

The Effects of Contemporary Systems of Agriculture

Low crop yields are among the immediate results of the prevailing systems of agriculture. Corn is produced and consumed in large quantities, yet the national mean yield in 1966-67 was only 13.6 quintales per manzana (roughly 14 bushels per acre). Bean production is also 
low, averaging an estimated 10.9 quintales per manzana (approximately 620 pounds per acre).?

On the other hand, cotton yields are high, giving 35 quintales of fiber per manzana (approximately 660 pounds per acre). The other crops produced using mechanization -- bananas, sugar, and, in some cases, coffee -also have higher yields. 8

As we have seen, primitive agricultural methods and soil depletion have brought about declines in production. This in turn is responsible for inadequate income and low levels of living for the majority of those who live in the rural areas. The gap is so great between the systems of agriculture used on the small-and medium-sized farms and the large mechanized operations that abandonment of the small operation is easier than an attempt to improve. For this reason, many migrate to the city and others leave for new lands to the east.

The Evolution of Agricultural Systems in Nicaragua

The cultural heritage that is applied to present-day agriculture in Nicaragua is rooted deep in time and in places beyond the limits of the Republic. Nicaragua, like

7 República de Nicaragua, Informe Annual, p. 93.

8 United Nations, Nicaragua: Características Generales de la Utilizacín y Distribución de la Tierra (Mexico City: Fo od and Agricultural Organization, 1967), p. 80 . 
all of Central America, was the scene of two converging types of native food production. Sauer has called them the "seed planting culture" and the "vegetable planting culture." The seed planters were centered to the north of Nicaragua near the present border of Honduras and Mexico. In this culture, a workable combination of corn, beans, and squash was developed. It found suitable soil of volcanic origin and an advantageous climate with a clear division between wet and dry seasons. From this center, the seed culture spread far to the north but only slightly to the south, reaching into the former Nicaraguan province of Guanacaste (now a part of Costa Rica). The seed planters did not inhabit all of Nicaragua but only what is today the Pacific region. 9

Everything that was done had its relation to corn and the corn field. The temples and sacrifices were used to assure a bountiful crop. The calendar year was divided according to the cycles of the corn field. There were ceremonies related to field location, water sources, field marking, cutting and burning trees, seed planting, weeding, ear bending, harvesting, storing the grain, and grinding the first meal. The tools that were used in this system of agriculture were few: the digging stick, the

${ }^{9}$ Carl 0. Sauer, Agricultural Origins and Dispersals (New York: The American Geographical Society, 1952), pp. $40-60$. 
stone axe, and the grinding stone (metate). The grain was transported on the backs of humans, about 75 pounds being considered a load and 8 to 10 leguas (approximately 35 miles) a day's journey. Fire had been used widely in the preparation of seed beds long before this period of history and was used here extensively. These were not nomadic groups, shifting from one spot to another, but were relatively stable. They gradually reached further into the forest to satisfy the needs for fuel and new lands. It was a workable system of agriculture and it allowed for enough surplus in production for the building of great temples, as are found in Guatemala and Mexico.10

The second cultural pattern of food production, that of the vegetable planters, came from a center in present-day Colombia. This pattern spread along the Atlantic watershed up through the areas currently in Panama, Costa Rica, Nicaragua, and on into Honduras. The most highly developed occupational skills were fishing, boating, and hunting. The crops were peanuts, pineapple, manioc (casava, yucca), sweet potatoes, peach palm (pejibae), malanga (root crop), and tobacco. The muscovy duck was the one common domestic animal, although some records mention a low-slung dog also. All of the humid Atlantic watershed 
of Nicaragua was considered the domain of this cultural pattern, although the population was extremely sparse. This area includes the present-day Atlantic region and most of the North-Central region. The nomadic life of the hunter and gatherer was common for most tribes; yet, there were sedentary beginnings: a river bank system of agriculture developed and animals were domesticated. ${ }^{11}$

At the time and in the area of the Spanish conquest of Nicaragua the agricultural arts of the seed planters were well advanced. The natives were cultivators of the soil and considered this as the main source of public wealth. Corn was the principal crop, and it was accompanied by beans, squash, and pumpkins. Cacao, cotton, tobacco, plantains, onion, sweet potatoes, potatoes, and various other root crops were also found. Magué was planted for both fiber and the juice that was easily fermented. Indigo was cultivated for tinting. A number of animals had been domesticated; deers, pheasants, mountain turkeys, wild pigs, and tepescuente (a piglike animal found only in Central America) were common. The most advanced tribes were the Niqueranos and Chorotegas living near the Pacific ocean. Their methods of agriculture and crop specialties were almost identical to those found today among the

11 Sauer, op. cit., pp. 40-60. 
Queche in Guatemala. Metal instruments such as simple axes and points for the digging stick had been perfected. Fire agriculture as a working system was the accepted cultural pattern. 12

There had been some cultural diffusion between the vegetable planters and the seed planters by the time of the Spanish conquest. Cacao came from the vegetable planters, but it was a highly prized crop among the seedplanting Pacific tribes. Special ceremonies were conducted during the seed selection, a ritual was used for germination, and the planters engaged in sexual relations the night before planting to insure fertility. This crop was of special interest because the seeds were used for money, and only the most wealthy could afford to use chocolate in their diet. 13

The Spaniards who came to Nicaragua were not farmers; yet they made a profound impact on the systems of agriculture that were to follow. Spain's agriculture in the fifteenth century was probably the most retarded of all western Europe. It was burdened by a latifundia system, which concentrated the control of the land in the hands of a few people. There was a monopoly of the mesta (the

12 José D. Gamez, Historia de Nicaragua (Managua: El País, 1889), pp. 37-56.

13 Ibid., p. 54 . 
sheep raisers' association) which allowed flocks to be driven across the central plateau, trample the cultivated fields, and thus accelerate erosion by stripping the hillsides of protective cover. The system of mayorazgo (primogeniture) passed on the estates intact to the oldest son of each family. This system allowed little breaking up of the large land holdings and even fostered a tendency for them to become larger. There was negligible incentive for effective use or improvement of agriculture under these circumstances. The tiller of the soil was considered to be at the very bottom of the list of preferred occupations, in contrast to the high prestige of the soldier, the cleric, or the poet. AII manual labor was held in "stubborn contempt."14

As a consequence of these traditional attitudes, large land holdings were important to the Spanish conqueror. They meant power, prestige, and a new home. He quickly set out to dominate the Indian who occupied the land. His object was to take the Iand away from the Indian, yet somehow keep him to work it. The priest Bartolomeo de las Casas was deeply disturbed by conditions in Nicaragua in the seventeenth century. He saw the planters in the area of León treat the Indian slaves worse than the Negro

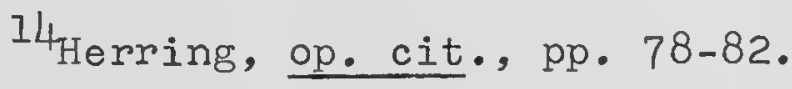


slaves had ever been treated in the West Indies. There was no distinction as to age, sex, or rank; all were forced to do the bidding of their masters, who "wasted their products in revelry." Las Casas writes bitterly, "If their contributions of corn were not punctually delivered, or if any part of their labor was not performed to the satisfaction of their masters, they were immediately condemned to death."15

There was an early introduction of Spanish animals and equipment into the territory of Nicaragua. In a letter of authorization sent by the king of Spain to the authorities in Panama on December 20, 1527, permission was given to move "horses, mares, cows, sheep, pigs," and other animals and equipment. 16 The list of practices and materials that came from spain includes: fertilization of crops, irrigation, seed selection, stock improvement, use of iron and steel implements, the wheel, the oxcart, oxen, chickens, hogs, sheep, goats, sugar, wheat, barley, oats, bananas, oranges, Iimes, peaches, and coffee. 17 Some of these importations flourished in the new land, such as the

${ }^{15}$ Carl Scherzer, Travels in Nicaragua (London: Longman, Brown, Green, Longman and Roberts, 1857), I, p. 92.

16 Andrés Vega Bolaños, Documento para la Historia de Nicaragua (Madrid: Ministerio de Educación de la Republica de Nicaragua, 1954), VI, 283.

17 Herring, op. cit., p. 201. 
horses that Iater ran wild in droves; others were shortIived because of unsuitable climate or of lack of interest on the part of the colonists.

The major change in agriculture after independence was in the Iabor supply. SIavery was no longer possible, although the reduction of this source through disease, escape, and killing had been considerable before that time. One of the earliest accounts of life in the Republic is found in the travel records of the German doctor, Scherzer, in 1857. He was dismayed at the low levels of production in a land with such great potential. Cattle and corn were the two main products. Indigo had been abandoned as a major crop. He sums up the situation by saying: "Trade, agriculture and industry alike languished under the blighted influence of war and civil discord." 18

A few years later Squier traveled extensively and observed "all of the known tropical plants": cotton, sugarcane, indigo, tobacco, rice, cacao, coffee, bananas, plantains, beans, tomatoes, yams, citrus, melons, limes, Iemons, oranges, pineapples, guavas, coconuts, sarsaparilla, vanilla, ginger, gum, and many others. Corn was seen everywhere and was the principal article of food.

18

Scherzer, op. cit., p. 120. 
Cattle were also important, and the hides were exported. In spite of the variety of products and the ease of marketing, there was little commercial agriculture at that time. 19

Toward the end of the nineteenth century another European traveler, Levy, wrote a detailed report of agriculture after his extensive visit to Nicaragua. He classified the farming into two categories: the huerta and the hacienda. The huerta was the name used for small plantings of products for every-day consumption, including corn and plantains. The hacienda was a large farm with a production specialty, although some diversity was needed to sustain the workers and the animals. Of particular interest were the haciendas dedicated to cattle, coffee, cacao, sugarcane, indigo, cotton, and rubber.

Levy described in detail the system of agriculture that was most common. In preparing land for planting, first came the socolar, where the small brush and vines were cut away; next the desmontar, where the large trees were chopped down but the roots were left in the ground; after a time of drying the quemar or burning was done to prepare for planting. Often it was necessary for a requemar, a second burning, where the land was new. When

${ }^{19}$ E. G. Squier, The States of Central America (New York: Harper and Brothers, 1858), pp. 363-68. 
corn was to be planted, the desmonte and quema were done at the end of the sumer. The planting was done as soon as the first rains came. In planting, a small bag of seed was tied to the bolt, and a metal pointed stick was used in the left hand to make the holes. Two and three grains were placed in each hole and then the foot was used to cover each hill.

The agricultural instruments used were listed as an axe, a machete, a hoe, a macana, a barreta (an allmetal pole), a shovel, an oxcart, a yoke and hitching equipment, and a sillon (packing frame) for the pack mule. Animal power common at that time was provided by oxen, pack mules, and riding horses. 20

Levy was most impressed by the inefficient agricultural practices. "The agricultural procedures in Nicaragua are yet, in most plantings, the same as they were 300 years ago and the innovations are only accepted with difficulty in the whole Republic." He calculated yields to be extremely low, considering the potential. He was also critical of cattle raising. Because it was in the hands of the richest and most influential families and required little labor except burning, it contributed to the backwardness of agriculture. Fences were not required

${ }^{20}$ Pablo Levy, Nicaragua (París: Librería Española de E. Denné Schmitz, 1873), pp. 442-49. 
on the cattle haciendas, and a fence law could never be passed because the Congress was dominated by the cattle men. Anyone wanting to plant had to fence the cattle out, which added considerably to the cost of production. 21

Recent trends in the use of animals can be observed in Table 16. The decrease in the use of oxen and the increase in the use of tractors (1,153 in $1952^{22}$ and 2,400 in $1955^{23}$ ) indicate some shift from rudimentary plow culture to mechanization. Many of the large farms have shifted from oxen to tractors, and a number of the smaller farmers hire tractor work done and no longer depend on oxen. The Atlantic region is still in a stage of development where fire agriculture prevails and is only gradually moving to rudimentary plow culture.

The increase of mules as compared to the decrease in oxen might suggest a shift to advanced plow culture. In reality, the mule is used more as a pack and riding animal than for pulling. The increase of mules in the Pacific could partiy be attributed to a change from oxcart to mule cart. This is particularly true in urban hauling.

\section{${ }^{21}$ Ibid., pp. 458-79.}

${ }^{22}$ Lyle B. Norris, Statistical Abstract of Latin America -- 1965 (Los Angeles: Latin American Center, University of California, 1966), p. 63.

${ }^{23}$ Pan American Union, América en Cifras 1965 Situación Económica: I (Washington: Instituto Interamericana de Estadistica, 1966), p. 27. 


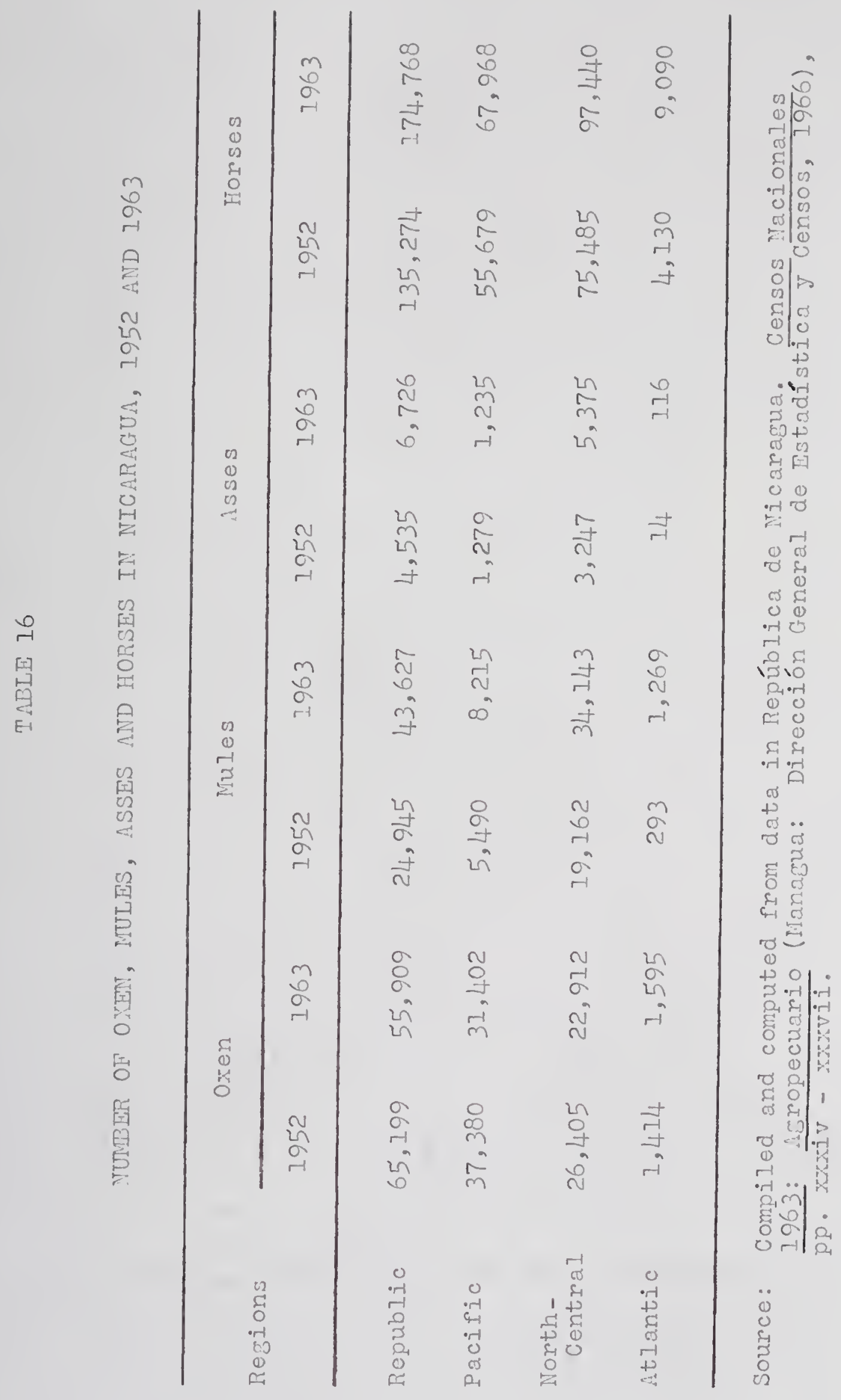


The North-Central zone relies heavily on pack animals to get products over rough terrain where only trails are available. In this same region, the number of asses has also increased. They are used for pack animals as well as for breeding purposes. The figures suggest that the North-Central zone serves as the major source of mules for the other regions.

Horses are used almost exclusively for riding purposes and as pack animals. The breed of horses used in Nicaragua is small and does not have the pulling power that a work horse needs. The increase in horses in all regions of the country is not related to any changes in systems of agriculture.

For the majority of those who work the land, the systems of agriculture have changed little since the time the seed planters first settled in Nicaragua. Fire is still the most common means of seed bed preparation. This is especially true when improved pasture land is included with crop land. The rudimentary plow system that was imported by the spaniards is giving way to mechanized agriculture. The hoe culture system still prevails on the coffee and cacao farms. Advanced plow culture has not been part of the development of agriculture in Nicaragua, nor will it likely be in the future. 
Summary and Conclusions

A system of agriculture is all of those ways and means used by man in taking products from the soil. It also includes the attitudes and values that motivate the activities. Because farming is a way of life which is integrated, it is not possible to separate the job categories that a farmer performs or even the different enterprises in which he is engaged. This concept is important in analyzing the productive aspect of man's relation to the land. Without an understanding of agriculture as a system, it is difficult to promote changes, although change must come if food production is to increase to meet the needs of an increasing population.

We have examined six systems that are used in the analysis of Nicaraguan agriculture. River bank plantings are the most primitive type: seeds are planted in the soft soil left by receding streams. There is little of this kind of planting in Nicaragua. Fire agriculture, which uses fire to burn off all that has grown on the land and leaves the soil clear for the desired crop, is one of the most common methods of planting in Nicaragua. Hoe culture is more advanced in that it uses tools. This system is also widely used in Nicaragua, the most common tool being the macana. Rudimentary plow culture, which makes use of animal power to pull simple tools, also is 
widespread in Nicaragua. Although advanced plow culture, characterized by horse-drawn equipment, is highly efficient, it is an almost nonexistent system in Nicaragua. Finally, mechanized agriculture is centered on the tractor and all the machines that go with it. This system is rapidly being adopted in the large commercial farming operations.

A number of factors are responsible for the contrast in agricultural systems in Nicaragua today. Attitudes toward land and work from the past, present-day education, lack of family-sized farms, lack of credit, lack of marketing facilities -- all of these work together to foster the use of traditional methods. On the other hand, where marketing facilities, credit, and technical help are available, such as in cotton, a jump from primitive plow culture to mechanization has taken place in a short time.

Because of the antiquated techniques used in much of Nicaraguan agriculture, yields are low. From low yields, low income and low levels of living follow. The history of man's agricultural relation to the land in Nicaragua goes back many centuries. In preColumbian times, there was a convergence of seed culture from the north and vegetable culture from the south. Later, the Spaniards brought animal culture and imposed a system of grazing as well as new cultivation techniques. Present-day agriculture in Nicaragua has elements of all 
this cultural past as well as some special adaptations caused by climate and geography. Though recent trends are toward mechanization, the majority of those who till the soil in Nicaragua are using techniques that were well known 5,000 years ago. 


\section{CHAPTER VIII}

\section{SUMMARY AND CONCLUSIONS}

The portion of the earth's surface that is called Nicaragua has many desirable characteristics as a place to live. Its natural endowments offer the possibility of livelihood to many people. The combination of rich soils, adequate rainfall, varied elevations, abundant sources of water, and a lengthy growing season offers the optimum conditions for plant and animal growth.

The population of this land base numbers slightly over 1,500,000. It is the least densely populated of the Central American countries. In relation to the land potential it is also sparsely inhabited.

of the total population, approximately 60 per cent is dependent on agriculture and stock raising for its livelihood. As nearly as can be calculated, approximately 140,000 families are thus employed. These families are almost evenly divided into two categories: farm operators and farm laborers. In general, the farm operators live on their land in isolated farmsteads. The farm laborers live in village-like clusters near their places of employment.

The distribution of the ownership and control of the land among the farm operators is very unequal. A 
small number of operators ( 1.5 per cent) control a high proportion ( 41.2 per cent) of the agricultural land. At the opposite extreme, a large number of operators $(35.4$ per cent) have the use of only a small proportion ( 1.5 per cent) of this land.

Just as the amount of land is unequally distributed, so are the property rights to the land. In Nicaragua the tenure rights tend to increase with the size of the farm. This means that the operators who have large farms also have greater legal security than those farmers with smaller tracts.

There has been no adequate method used to survey the land in Nicaragua, and most land divisions and property boundaries are open to dispute. This further contributes to the uncertainty of land possession.

Many contrasting methods are used in extracting products from the soil. Fire is used in a high proportion of the farms as an aid to agriculture. Sometimes this is the major operation and the production system is merely felling and burning or fire agriculture. Rudimentary plow culture is also common where the oxen are able to work on level land. Hoe culture is often used in the growing of row crops. Mechanized agriculture is increasing where commercial crops are grown for export.

There are three geographical regions in Nicaragua, and man's relation to the land varies somewhat from region 
to region. The Pacific region contains a high proportion of level lands, and the year in this area is divided into two seasons: wet and dry. Two-thirds of the population of the Republic live here, but the proportion engaged in agriculture and stock raising is lower than in the other regions. It is here that the concentration in ownership and control of the land is the highest. Some other characteristics of this region are: large numbers of agricultural laborers; a large proportion of minifundia; an unusually large amount of the land area which has legal title; a considerable amount of absentee ownership; a major part of the land dedicated to commercial crops for export; and rapid mechanization of agriculture.

The North-Central region has a more varied climate and topography. It has fewer urban centers here than the Pacific region, and relatively more of the inhabitants are engaged in agriculture and stock raising. This region contains an unusually great proportion of familysized farms. Other characteristics of the region are: a high proportion of isolated farmsteads; extensive use of fire agriculture, hoe culture, and rudimentary plow culture; and relative inaccessibility to markets and other services.

The Atlantic region is the largest in area, but vast portions of it are unused. The topography is rugged, and the rainfall constant. Few roads have been 
constructed, and boats are the common mode of transportation. The population in this region is sparse and most of its inhabitants are settled along the navigable parts of the rivers. Most of the farm personnel are operators of subsistence plots. Some of the farms are extremely large, but the possessors of most of them lack legal titles. Here fire agriculture is used extensively. Some cattle are produced on a commercial basis.

The causes of the unequal distribution of the rights to the land and its products among the farm personnel range from historical to cultural. The ways in which the rights to the land were given out at the time of the Spanish conquest established a cultural pattern that has been modified only slightly over the years. Because of the strategic location of Nicaragua, international politics has fostered internal violence in which the victors have claimed the spoils (including the ownership and control of land). Modern communication and cultural interchange have introduced new techniques. These new techniques, such as those applied to the production of cotton, contrast greatly to those used by the large majority of the farm population. Population is increasing rapidly, and so are the expectations of what life should offer to the individual. Access to land continues to be seen as the road to position, prestige, and economic security. At the same time, the demand for 
products that can be secured on a large scale and with the efficiency of mechanized methods does not foster breaking up the large farms so that a more even distribution of this essential item for "the good life" can be accomplished. Cultural patterns are hard to change, particularly when the present system is profitable to those who have vested interest in the present situation.

The effects of the present relations of man and land in Nicaragua are also many and complicated. As a direct result, the capabilities of both the land and the people are being used inefficiently. Moreover, some of the cultivation methods are resulting in a rapid depletion of the soil. At the same time the low economic and educational levels of most of the farm personnel probably contributes to the rapid increase of the population. The purchasing power of the farm laborers and operators of subsistence plots does little to stimulate manufacturing; and the lack of industry in turn denies alternative employment opportunities to those who would like to change occupations.

The large proportion of the farm personnel which is engaged in routine physical labor and is denied opportunities for decision-making, results in little incentive for increased efficiency in production. Good yields are found only in those export crops that are produced by mechanized techniques. 
The inability of the small farmers to acquire desirable land and the insecurity of boundaries and legal possession all make for the least possible investment in the production process of time, energy, and capital. For this reason, it is much easier for them to continue using the systems of agriculture of the past than to try new ways that only add more uncertainties to an already insecure existence.

For those who have sought to claim land for their own, the price has been isolation. The isolated farmsteads of the North-Central region, the Atlantic region, and even the hills and mountains of the Pacific region are without the services, including medical care, education, and communication, that allow for effective social interaction.

The over-all situation relative to the relations to the land of the families that depend on agriculture for a livelihood has been listed by the director of the Agrarian Reform Institute as follows: Approximately 50,000 families $(400,000$ people) are landless; another 50,000 families have very little land; and only 10 per cent of those related to agriculture and stock raising are proprietors of large farms. Thus, from 80 to 90 per cent of the rural population lack land. Moreover, they are illiterate, in poor health, and depend on curanderos (spiritist healers). They are undernourished, they pay 
a high rent; they are in debt, lose half the value of the crop in the marketing negotiations, and they are forced to buy at high prices. Further, the yields are so low that in the year 1963-64, 161,465 quintales ( 1 quintal $=100$ pounds) of corn, 192,000 quintales of rice (30 per cent of the amount produced nationally), and $2,911,948$ kilos ( 1 kilo $=2.2$ pounds) of milk products were imported. I

Many of the components of the present institutions governing man's relation to the land in Nicaragua have been borrowed from other cultures. Prior to the arrival of the Spaniards two cultures existed in this area: (I) a seed growing culture had been brought by peoples from the north and this was localized in the western part of the country; and (2) a vegetative planting culture, which had been brought up from the south. The Spanish conquest was also an attempt at cultural domination which almost succeeded; yet some of the pre-Columbian practices continue in use today. In more recent times the ideal of the family-sized farm and the components of a mechanized system of agriculture have been borrowed from the United States and western Europe.

The most recent trends may be sumarized as follows: (I) there has been a continuous addition of virgin lands

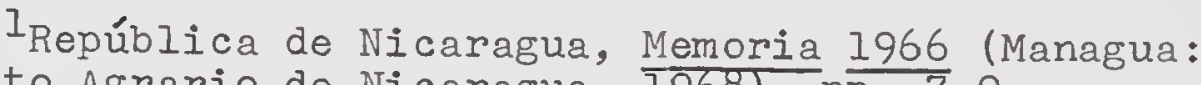
Instituto Agrario de Nicaragua, 1968$),$ p. 7-9. 
to the area already under cultivation produced by an increasing number of settlers who are colonizing the forest and mountain areas on a voluntary and individual basis; (2) there is some increase in the number of people who depend on agriculture and stock raising for a livelihood, but a considerable decrease in the proportion of farmers in the total population; (3) the number of farm operators who own or control enough land or enough security of tenure to enable them to gain a livelihood for their families that will meet their standards is decreasing; and (4) congressional leaders are reluctant to make necessary changes in laws that might promote access of all farm families to the agricultural land.

Up to this point the trends mentioned have emphasized problems more than improvements. There are, however, a number of developments already in process which may bring improvements. The Agrarian Reform Law of 1963 is one of these. The major goal of its proponents is to increase the number of family-sized farms, thereby increasing the volume of farm products and bringing about a more equitable distribution of the same among the population. Already over 1,300 farms have been distributed to farming families. Most of this has been done in the colonies that have been established in the Pacific region. The success has been over played, but it has been great enough to prove that this is a workable method. 
The aerial mapping program has progressed to the point that a new system of property survey, based on permanent fixed points, soon can be used. This should help in defining the boundaries of lands and make more exact descriptions of properties possible in the deeds to the same. As this is done, the land tax may be implemented to provide money for further improvement of the social conditions in the rural areas. Unfortunately, an enabling act ordering completion of the survey project and obligating the payment of property taxes on the land has not been passed by Congress.

Another development which must be taken into account in the future consists of the growing demands of farm laborers who expect something better from life than they have known in the past. All of them have visited the cities and some have remained in them; but even those who return to the country now realize that there are attractive alternatives.

Those in responsible government positions agree that the discontent of the laborers should not be allowed to increase indefinitely. The desire for ownership of land by the landless is great; and the amount of land that is unclaimed or of doubtful ownership also is considerable. Present plans are to make these two factors offset one another and thus improve the over-all relations of man and land in the Republic. 


\section{GLOSSARY}

The definitions given for the following Spanish terms are according to general usage in Nicaragua and may not correspond exactly with the meaning in other Spanish-speaking countries.

Aparcero: share cropper or share hand. Arrendado: rented.

Arrendatario: one who operates a farm on rented land.

Arrimado: a migratory laborer who lives temporarily on another's land.

Asiento: a contract for the legal transfer of land.

Bueyes: oxen.

Barreta: a crowbar.

Carta de venta: a notarized bill of sale.

Caserio: a disorderly grouping of the huts of the campesinos.

Colono: an agricultural laborer who is paid in usufruct of a small plot of ground on a large hacienda or plantation as partial payment for his work.

Comarca: a subdivision of the municipio; it is the smallest administrative unit in Nicaragua.

Comunero: a person operating a farm on land belonging to a municipio.

Cordova: a unit of Nicaraguan money; I Cördova equals $\$ 0.14$ US. 
Cruzar: to cross; plowing land for the second time at right angles to the first plowing.

Cruzeta: a wooden cross frame placed on a horse's back and used for holding the pack.

Cultivos anuales: annual crops.

Cultivos permanentes: perennial crops.

Curandero: a spiritist healer (quack-doctor).

Departamento: one of the major or state-like political units into which Nicaragua is subdivided.

Desmontar: to cut down the large trees in preparation for planting.

Desmonte y quema: felling and burning.

Fjiditario: see "comunero."

Ejido: lands belonging to a municipio.

Encomienda: a grant of Indians, during the colonial period, requiring the grantee to provide for the spiritual and temporal welfare of his charges, and giving him the privilege of exacting tribute from them.

Espeque: planting stick.

Fazenda: large landed estate as found in Brazil.

Fundo: large landed estate as found in chile.

Hacienda: type of large farm in Spanish America; usually used for cattle production.

Huerta: a farm dedicated to small plantings of products for home consumption.

Inquilino: a farm laborer in Chile.

Kilo: a unit of weight equal to 2.2 pounds.

Latus Fundus: the "broad estates" first observed in the Roman Empire about $80 \mathrm{BC}$. 
Latifundia: extremely large farms on which little, if any, attempt is made to make an intensive use of the land.

Legua: a unit of linear measure, approximately equal to four kilometers.

Lindero: property line.

Macana: long-handled instrument used for hand cultivating; much like the hoe except that it is open faced and is pushed instead of pulled.

Machete: long-bladed knife.

Magué: a crop grown for fiber.

Malanga: a root crop (yanthasoma spp.).

Manioc: yucca (manihot esculenta).

Manzana: a unit of land measurement equal to 0.7 hectares or 1.7 acres.

Mayorazgo: the system of primogeniture that passed on the estates intact to the oldest son in each family.

Merced: a land grant.

Mesta: the sheep raisers association of Spain at the time of the conquest.

Metate: a grinding stone for corn meal.

Minifundio: a small subsistence farm.

Ministerio de Economía: Ministry of Economics.

Municipio: a county-like political subdivision.

ocupado sin título: land occupied without legal title.

Ocupante: one who occupies land that legally belongs to another, a squatter.

Otras formas de tenencia: other forms of tenancy. Paracaidista: see "ocupante." 
Patrimonio familiar: family estate.

Patrono: land owner who hires laborers.

Pejibae: peach palm. (Guilielma gasipaes.)

Peones: farm laborers.

Pilón: large mortar and pestle.

Poseador: a person who occupies land that has no legal owner.

Precarista: see "ocupante."

Propias: owner operated lands.

Propietario: land owner.

Quinta: country house of well-to-do Nicaraguan.

Quintal: unit of weight equal to 100 pounds.

Quemar: to burn (as in preparation for planting).

Registro de propiedad: property registry.

Requemar: to burn land over for the second time.

Sillon: a packing frame for a mule.

Socolor: to cut the small brush and vines in preparation for planting.

Tepescuente: a pig-like animal found only in Central America.

Tierras baldías: unpatented portions of the public domain.

Tierras con bosques y montes: forest lands.

Tierras con pastos naturales: land in natural pastures.

Tierras con pastos sembrados: land in planted pastures.

Tierras en descanso: fallow land.

Timón: the tongue of a plow. 
Titulo provisorio: a provisional title to the land.

Unidad de explotacion agropecuario: an agricultural stock raising unit or roughly a farm.

Usufructario: one who is given the right to plant and harvest on the land belonging to another.

Usufructo: usufruct.

Vara: a unit of linear measure equal to 32.8 inches. 


\section{BIBLIOGRAPHY}

Ackerman, J. and Harris, Marshal. (eds.) Family Farm Policy. Chicago: University of Chicago press, 1947 .

Alers Montalvo, Manuel. Sociología: Introdución a su uso en Programas Agricolas Rurales. Turrialba: Editorial SIC, 1960 .

Arce, M. Antonio. Sociología y Desarrollo Rural. San Jose: Lehmann, $196 \overline{1 .}$

Baali, Fuad. Relation of the People to the Land in Southern Iraq. Gainesvilie: University of Firlorida Press, 1966.

Bagú, Sergio. Estructura Social de la Colonia. Buenos Aires: El Ateneo, 1952.

Bennett, Ernest M. Problems of Village Life. London: Williams and Norgate, 1914 .

Blandon, Alfonso. Land Tenure in Nicaragua. Unpublished master's the sis. Gainesville: University of Florida, 1962.

Bolaños, Yela, J. Ramiro. Breve Recopilación de Aspectos Economico-Geograficos de centro America y el Mundo. Guatemala: Fieria del Libro, 1958.

Bradford, Sax. Spain in the World. New York: D. Van Nostrand, $\overline{1962}$

British Government. The Mosquito Territory. London: T. R. Harrison, 1848 .

Brown, Lester R. Man Land and Food (Foreign Agricultural Economic Report $\overline{\text { NO. }}$ II.) Washington: USDA, Economic Research Service, 1963.

Brunner, Edmund de S. Village Communities. New York: George H. Doran Company, 1927 . 
Brunner, Edmund de So, Hughs, Gwendolyn S., and Patten, Marjorie. American Agricultural Villages. New York: George H. Dor an Company, 1927.

Brunner, Edmund de S., and Kolb, John H. Rural Social Trends. New York: McGraw-Hill Book Company, 1933.

Brunner, Edmund de S., Sanders, Irwin T., and Ensminger, Douglas (eds.) Farmers of the World. New York: Columbia University Press, 1945.

Carroll, Thomas F. Land Tenure and Land Reform in Latin America. Washington: Inter-American Development Bank, 1965.

Carvalho, Hernani de. Sociología de Vida Rural Brasileira. Rio de Janeiro: Editora Civilizacao Brasileira, 1951.

Clements, Harold M. A Sociological Study of the Mechanization of Agriculture in Minas Gerais, Brazil. UnpubIished dissertation. Gainesville: University of Florida, 1966.

Cole, J. P. Latin America: An Economic and Social Geography. Washingt on: Butterworths, 1965.

Committee for Economic Development. Cooperation for Progress in Latin America. Ne work: Res earch and Policy Committee of CED, 1961.

Committee for Economic Development. Economic Development of Central America. New York: - Research and Policy Comittee of CED, 1964.

Committee for Economic Development. How Low Income Countries Can Advance Their Own Growth. New York: Research and Policy Committee of CED, 1966.

Consejo Superior Universitario Centro-Americano. El Sistema Educativo en Nicaragua. San José: Secretaria Permanent e deI CSUCA, 1965.

Corredor, Berta and Torres, Sergio. Transformación en el Mundo Rural Latino Americano. Bogotá: Centro de Investigaciones Sociales, 1961.

Crist, Raymond E. "Tropical Subsistence Agriculture in Latin America" in Smithsonian Report for 1963. Washington: Smithsonian Institution, 1964 . 
Crow, John A. The Epic of Latin America. Garden City:

Doubleday and Company, Inc., 1946.

Ducoff, Louis J. "The Role of Migration in the Demographic Development of Latin America." Milbank Memorial Fund Quarterly, Vol. 43, No. 4 (1965).

Durand, John D. and Pelaez, Cesar A. "Patterns of Urbanization in Latin America." Milbank Memorial Fund Quarterly. Vol. 43, No. 4(1965).

Elizaga, Juan C. "Internal Migrations in Latin America." Milbank Memorial Fund Quarterly, Vol. 43, No. 4, (1965).

Encyclopaedia Britannica, 1949 edition, Vol. II.

Evans, Hubert. Nicaragua. London: Her Majesty's Stationery Office, 1954 .

Fals-Borda, Orlando. A Sociological Study of the Relationships Between Man and the Land in the Department of Boyacá, Colombia. Unpubli shed dissertation. Gainesville: University of Florida, 1955.

Fals-Borda, Orlando. Peasant Society in the Colombian Andes. Gainesville: University of Florida Press, $\overline{1962 .}$

Ford, Thomas R. Man and Land in Peru. Gainesville: University of Florida Press, 1955.

Freyre, Gilberto. The Masters and the Slaves. New York: Alfred A. Knopf, 1946.

Galpin, Charles J. The Social Anatomy of an Agricultural Community. Wisconsin Agricultural Experiment station Bulletin 34, Madison, 1915

Gamez, José D. Historia de Nicaragua. Managua: El País, 1889.

Gillette, John M. Constructive Rural Sociology. New York: Sturgis and Walton, 1913.

Gillette, John M. Rural Sociology. New York: The Macmillan Company, 1922.

Goode's World Atlas. (l2th Edition). Chicago: Rand MeNalIy and Company, 1964. 
Greaves, Ida C. "Plantations in World Economy," in Pan American Union Plantation Systems of the New World. Social Science Monograph VII. Washington: Organization of American States, 1959.

Gumm, Clark L. "Report on the Establishment of a Cadaster for Nicaragua." Unpublished Report by Chief Cadastral Engineer of Bureau of Land Management of the United States Department of the Interior, 1965.

Hanke, Lewis. Mexico and the Caribbean. Princeton: D. Van Nost $\overline{r a n d}$ Co., $1 \overline{959 .}$

Heaton, Louis E. Rural Development in Latin America. New York: American International Association for

Economic and Social Development, 1963.

Herring, Hubert Clinton. A History of Latin America. New York: Alfred A. Knop $\bar{f}$, I955.

International Bank for Reconstruction and Development. The Economic Development of Nicaragua. Baltimore: The Johns Hop kins Press, $195 \overline{3}$.

James, Preston E. Latin America. New York: The Odyssey Press, 1959.

Kolb, John H. and Brunner, Edmund deS. The Study of Rural Society. Cambridge: The Riverside Press of Houghton-Mifflin, 1952.

Kalijarvi, Thorsten V. Central America: Land of Lords and Lizards. New York: D. Van Nostrand Co., $1 \overline{962 .}$

Kingsbury, Robert $C$. and Schneider, Ronald M. An Atlas of Latin American Affairs. New York: Praeger, 1965.

Landis. Paul H. Rural Life in Process. New York: McGraw$\mathrm{Hi} 11,1940$.

Leonard, Olen E. Bolivia: Land, People and Institutions. Washington: The Scarecrow $\overline{\text { Press, }} \overline{195} 2$.

Leonard, Olen E. Canton Chullpas: A Socioeconomic Study in the Cochabamba Valley of Bolivia. Washington: office of Foreign Agricultural Relations, 1948.

Leonard, Olen E. Pichilingue: A Study of Rural Life in Coastal Ecuador. Washing Fon: Office of Foreign Agricultural Relations, 1947 . 
Levy, Pablo. Nicaragua. París: Librería Expañola de E. Denné Schmitz, 1873.

Lockley, Lawrence C. A Guide to Market Data in Central America. Tegucígalpa: Central Americ $\overline{a n}$ Bank for Economic Integration, 1964.

Loomis, Charles P., and Beegle, J.Allan. Rural Social Systems. New York: Prentice-Hall, $\overline{1950 .}$

Loomis, Charles P., and Beegle, J. Allan. Rural Sociology: The Strategy of Change. Englewood Cliffs: Prentice HaI1, 1957 .

Loomis, Charles P., et. al. Turrialba: Social Systems and the Introduction of Change. GIencoe: The Free Press, 1953.

Lyle, Norris and Colman, Richard A. Statistical Abstract of Latin America ( 9 th Ed.) Los Angeles: Center of Latin American Studies, 1965.

Martz, John D. Central America: The Crisis and the Challenge. Chapel Hill: The University of North Carolina Press, 1959.

Maturana, Sergio. "Land Tenure" in Egbert de Vries (ed.), Social Research and Rural Life in Central America, Mexico and the carib bean Region. Paris: The United Nations Educational and Scientific Commission, 1966.

McBride, George M. Chile: Land and Society. New York: American Geographical Society, $\frac{1936 .}{1936}$

Mortara, Giorgio. Caracteristicas de la Estructura Demográfica de los Paises Americanos. Washington: Pan American Union, $\frac{1964 .}{196}$

Neilson, N. Medieval Agrarian Economy. New York: Henry Holt and Co., 1936.

Nelson, Lowry. The Mormon Village. Salt Lake City: University of Utah Press, 1952.

Nelson, Lowry. The Mormon Village: A Study in Social Origins, Brigham Young University Studies Number 3. Provo, Utah: Brigham Young University, 1930.

"elson, Lowry. Rural Cuba. Minneapolis: University of Minnesota Press, 1950. 
Pan American Union. América en Cifras 1965. (Situación Económica: 1. Agricultura, Ganaderia, Sivilicultura, Caza J Pesca.) Washington: Instituto Interamericano de Estadística, 1966.

Pan American Union. Características de la Estructura Demográfica de los Paises Americaños. Washington: Instituto Inter-Americano de Estadrstica, 1964.

Pan American Union. Central America. Washington: Interamerican Committee for Agricultural Development, no date.

Pan American Union.
Nicaragua 1950. Washington: $\frac{\text { Constitution }}{\text { Organization }} \frac{\text { of }}{\text { Of }}$ American States, 1966.

Pan American Union. Nicaragua. Washington: Organization of American St $\overline{a t e s, 1964 .}$

Parsons, Kenneth H., Penn, Raymond J., and Raup, Philip M. (eds.) Land Tenure. Madison: The University of Wisconsin Press, 1956.

República de Nicaragua. Censo General de Población 1950. Managua: Dirección General de Estadrstica y Censos, 1954 .

República de Nicaragua. Censos Nacionales 1963 Agropecuario. Managua: Dirección General de Estadistica y Censos, 1966.

República de Nicaragua. Censos Nacionales 1963 Educación Volumen I. Managua: Dirección General de Estadistica $\overline{\mathrm{y}}$ Censos, 1964 .

República de Nicaragua. Censos Nacionales 1963 Población Volumen I. Managua: Direccion General de EstadIstica $\bar{y}$ Censos, 1964 .

República de Nicaragua. Censos Nacionales 1963 Población Volumen II. Managua: Dirección GeneraI de EstadIstica $\frac{1}{\mathrm{y}}$ Censos, 1965 .

República de Nicaragua. Censos Nacionales 1963 Población Volumen III. Managua: Dîreccion General de Estadistica $\bar{y}$ Censos, 1967.

República de Nicaragua. Censos Nacionales 1963 Población Volumen IV. Managua: Di rección General de EstadIstica $\bar{y}$ Censos, 1967. 
República de Nicaragua. Censos Nacionales 1963 Población Volumen $V$. Managua: Direccion General de EstadIstica $\bar{y}$ Censos, 1967.

República de Nicaragua. Censos Nacionales 1963 Vivienda Volumen I. Managua: Dirección General de EstadIstica $\frac{\bar{y}}{\text { Censos, } 1965 .}$

República de Nicaragua. Censos Nacionales 1963 Vivienda Volumen II. Managua: Dirección General de EstadIstica $\bar{y}$ Censos, 1965.

República de Nicaragua. Colonias Agrícolas: Reglamento. Managua: Instituto Agrario de Nicaragua, 1964.

República de Nicaragua. Informe Anual. Managua: Banco Central de Nicaragua, 1967.

República de Nicaragua. Ley de Reforma Agraria. Managua: Instituto Agrario de Nicaragua, 1966.

República de Nicaragua. Masaya Rural: Socio Económico. Managua: Instituto Agrario de Ni caragua, 1967.

República de Nicaragua. Memoria. Managua: Instituto Agrario de Nicaragua, 1967.

República de Nicaragua. Memoria 1966. Managua: Instituto Agrario de Nicaragua, 1968.

República de Nicaragua. Plan Nacional de Desarrollo Económico y Social de Nicaragua 1965-1969 (Parte I) Manacua: Oficina de Planificacion-Consejo Nacional de Economia, 1965.

República de Nicaragua. Plan Nacional de Desarrollo Fconómico y Social de Nicaragua $1965-1969$ (Parte II) Managua: Oficina de Planificación-Consejo Nacional de Economía, 1965.

República de Nicaragua. Presupuesto General 1965. Managua: Ministerio de Hacienda y Credito Público, 1964.

República de Nicaragua. Presupuesto por Programas 1966. Managua: Ministerio de Hacienda y Crédito Público, 1966 .

República de Nịicaragua. Publicaciones de la D.G.C. Managua: Dirección General de Cartografia, $1 \overline{968}$. 
República de Nicaragua. Registro de Propiedad, Año 1883. Masaya: Oficina de Registro Ptublico, $188 \overline{3}$.

Roa M., Alfredo. Sociological Study of the Relations of Man to Land in El Valle del Cauca, Colombia. Unpublished master's the sis. Gaine sville: University of Florida, 1964.

Ross, Edward A. South of Panama. London: George Allen and Unwin, $\overline{\text { Ltd., }} \overline{19} 1 \overline{5 .}$

Ross, Edward A. The Social Revolution in Mexico. New York: The Century Company, 1923.

Royal Institute of International Affairs. Agrarian Reform in Latin America. Oxford: Oxford University Press, $\overline{1962 .}$

Rubin, Vera (ed.) Plantation Systems of the New World. Washington: Pan American Union, 1959.

Rycroft, W. Stanley and Clemmer, Myrtle M. A Factual Study of Latin America. New York: COFMAR/Presbyterian, 1963.

Rycroft, W. Stanley and Clemmer, Myrtel M. A Study of Urbanization in Latin America. New York: CoEMAR/ Presbyterian, 1963.

Salazar N., José Manuel. Tierras y Colonizacion en Costa Rica. San José: Universidad de Costa Rica, $\overline{1962 .}$

Sanderson, Dwight. Rural Sociology and Rural Social Organization. New York: John Wi ley and Sons, 1942.

Sauer, Carl 0. Agricultural Origins and Dispersals. New York: The American Geographical society, 1952.

Saunders, J. V. D. "Man-Land Relations in Ecuador" Rural Sociology. March, 1961.

Scherzer, Dr. Carl. Travels in Nicaragua. Vol. I. London: Longman, Brown, Green, Loñgman, and Roberts, 1857.

Schulman, Sam. A Sociological Analysis of Land Tenure Patterns in Latin America. Doctoral Dissertation. Gainesville: University of Florida, 1954.

Senior, Clarence. Land Reform and Democracy. Gainesville: University of Florida Press, 1958. 
de Shaya, Yolanda di Geronimo. An Analysis of Land Tenure and Size of the Agricultural Holdings in Venezuela. Unpublished thesis. Gainesville: University of Florida, 1962.

Simpson, Eyler N. The Ejido: Mexico's Way Out. Chapel Hill: University of North Carolina press, 1937.

Small, Albion W. and Vincent, George E. An Introduction to the Study of Society. New York: American Book Comp any, 1894 .

Smith, T. Lynn (ed.) Agrarian Reform in Latin America. New York: Alfred A. Knopf, 1965.

Smith, T. Lynn. Brazil: People and Institutions. Baton Rouge: Louisiana state University Press, 1946, 1948 , 1954 .

Smith, T. Iynn. Colombia: Social Structure and Process of Development. Gainesville: University of Florida Press, 1967.

Smith, T. Lynn. Latin American Population Studies. Gainesville: University of Filorida Press, 1960.

Smith, T. Lynn. Sociolofía Rural. Maracaibo (Venezuela): Universidad del Zulia, Facultad de Agronomía, 1963.

Smith, T. Lynn. The Process of Rural Development in Latin America. Gainesville: University of Filorida $\overline{\text { Press }}$, 1967 .

Smith, T. Lynn. The Sociology of Rural Life. New York: Harper and Brothers, 1940, 1953 .

Smith, T. Lynn, Diaz Rodriguez, Justo and García, Luis Roberto. Tabio: A Study in Rural Social Organization. Washington: - Office of Foreign Agricultural Relations, 1945.

Solari, Aldo E. Sociología Rural Latino-Americano. Buenos Aires: Editorial Universit aria de Buenos Aires, 1963.

Sorokin, Pitirim A., Zimmerman, Carle C., and Galpin, Charles J. A Systematic Source Book in Rural Sociology. Minneapolis: University of Minnesota Press, 3 Vols., $1930-1932$.

Squier, F. G. The States of Central America. New York: Harper and Brothers, 1858 . 
Taylor, Carl C. Rural Life in Argentina. Baton Rouge: Louisiana State University Press, 1948.

Taylor, Carl C. Rural Sociology. New York: Harper and Brothers, $\overline{1926 .}$

Taylor, Carl C. et al. Rural Life in the United States. New York: Alfred A. Knopf, $\overline{194} \overline{9}$

Terpenning, Walter A. Village and Open Country Neighborhoods. New York: The Century Company, 1931.

United Nations. Nicaragua. Washington: Food and Agriculture Organization of the United Nations, 1950.

United Nations. Nicaragua: Características Generales de la Utilizacion y Distribucion de la Tierra.

TPreliminary Report) Mexico City: Food and Agricultural Organization, 1967.

United Nations. Statistical Bulletin for Latin America, Vol. IV. No. 1. New York: Economic Commission for Latin America, 1967.

United Nations. The Demographic Yearbook, 1965. New York: Department of Economic and Social Affairs, 1966.

United Nations. The Statistical Yearbook, 1964. New York: Department of Economic and Social Af fairs, 1965.

United States Government. Latin American USOM Seminar on Agrarian Reform. Washington: International Cooperation Administration, 1961.

United States Government. Resources Survey for Latin American Countries. Washington: Department of state, $\overline{1965 .}$

Vega Bolaños, Andrés. Documentos para la Historia de Nicaragua. Tomo Primero. Madrid: Ministerio de Educación de la República de Nicaragua, 1954.

Vogt, Evon A. Introduction to Rural Sociology. New York: D. Apple ton and Company, 1917 .

de Vries, Egbert. Social Research and Rural Life in Central America, Mexico and the Caribbean Region. Paris: UNNESCO, 1966.

Whetten, Nathan L. Guatemala: The Land and the People. New Haven: Yale University press, 196 I. 
Whetten, Nathan L. Rural Mexico. Chicago: University of Chicago Press, 1948.

Winnie, William ., Jr. The Lower Papaloapan Basin: Land and People. Unpublished Dissertation. Gainesvîile: University of Florida, 1956.

Zimmerman, Carle C., et al. Problems of the New Cuba: Report of the Commission on Cuban Affairs. New York: Foreign Policy Association, 1935. 


\section{APPENDIX \\ RURAL LIFE IN NICARAGUA}

The following paragraphs are selections from the entries made in my daily journal. These notes were taken over a period of seven years on as many visits to Nicaragua. Some of the areas and farms have been revisited so that some of the paragraphs include changes that are taking place.

There are many details that are lacking in official publications but yet needed to give one a feeling of how things operate in a society foreign to him. Field observations help one see how everything fits together and serve to give further meaning to statistical data. This section is included because it does fill in some of these details that give added insight into rural life in Nicaragua.

(December 10, 1961) While flying over Nicaragua, I have been impressed by the lakes and the volcanos. It appears that some of these volcanos are still active and others have been in recent activity.

Upon arriving at the airport, I noted a number of contrasts to the conditions that I left in Costa Rica some 50 minutes before. The weather here is much warmer and it is dry. The people are of darker features generally, and their manner is less reserved than I had grown accustomed to in Costa Rica.

I am also impressed by the presence of military personnel and installations. There are many uniformed 
officials at the airport. Along the highway into Managua all traffic is stopped and checked at a military post.

(December 16, 1961) Conversations throughout the week with the young men in the seminar (Literacy and Community Development) emphasize the low levels of education that prevail in the rural areas. Some localities that they mentioned still have no school facilities and it is rare to find a person who can read and write.

Don G. discussed at length his problems as a teacher in the school he and some interested neighbors had started in the northern departamento of Nueva Segovia. He mentioned the extreme isolation of the people who live on their subsistence plots and the lack of social contact which make the children fearful of strangers.

A visit to the Managua market today gave me a good idea of the products that are grown and consumed by most people. Corn is used in many forms and specially in small "tortillas." Both tortillas and tamales are sold ready to eat, or the ground corn paste can be purchased to take home to cook. The majority of the fruit and vegetable products seem to be sold by individuals who have portable stands set up in the street in the center of the market area. Most of these stands are tended by women.

In spite of the military check points on the highway, everyone seems to be traveling. There are many buses coming in from outlying areas, covered with dust, in varying states of repair, but always full of people and of products for sale. Numerous pick-up trucks, jeeps and microbuses also carry people and products to and from the city.

(September 23, 1962) Few things seem to have changed since my visit in 1961. In the airport-Managua area, there appear to be more small industrial plants than before.

(September 24, 1962) The trip to Diriamba took about an hour. We drove southwest from Managua up into the highlands. The air is cool and damp compared to the heat of the city. We passed through an area that had been blighted by volcanic gases a few years before. The crops in the area had been completely destroyed and still have not been replanted because of poor soil conditions. The remains of a few houses can be seen.

Diriamba is the center of a coffee growing district and has a different aspect than Managua. The air is cooler 
than in the lowlands. The streets are cleaner, although many are not paved. The pace of life seems slower than in the capital city. There are some isolated farmsteads to be seen in the surrounding countryside, but most of the families seem to live in small village clusters. I was told that most of the coffee is grown on large farms instead of small- and medium-sized units.

(September 28, 1962) Twenty-four people have been taking part in the weeklong seminar on Literacy and Community Development. During the week it has been possible to learn something of the social, economic, and educational problems in the different areas of the country. Nine of the sixteen departamentos were represented in the group. Half of those present were rural pastors, and the rest were teachers. Some of the pastors also serve as school teachers. One of the frequently expressed concerns was that of a lack of adult motivation to learn. There is also some anxiety over political unrest.

(July 26 to 29, 1964) The purpose of this trip was to locate the best places for field work experience for the 39 trainees of the International Seminar on Literacy and Community Development being held at the time in Costa Rica. The brief visits to León, Central San Antonio, El Salto, Sabana Grande, and Tipitapa gave an opportunity to see parts of Nicaragua not seen before. These are all in the western and most populated area of the country. There are a number of large agricultural operations such as sugar, cotton, and cattle farms in this area. The people live in village clusters for the most part. Don R. (El Salto) mentioned 16 cluster villages that he visits frequently on foot or bicycle.

The houses in these villages are built of varied materials. There are a few made of cement blocks with tile roofs. Others use wood, adobe, or palm bark for siding. Some used tin or palm leaves for roofing material. A few homes have cement tile, or wood floors, but most have only packed dirt. Few toilets can be observed throughout the countryside, and water comes from neighborhood wells or is carried from a stream or river.

(November 5, 1964, trip by chartered bus from Alajuela, Costa Rica to Managua) We crossed the frontier at $2: 30$ p.m. In general, the highways of Nicaragua seem to be in better condition than those of Costa Rica. Long stretches of area between Lake Nicaragua and the Pacific Coast are used for cattle grazing. There are few houses and not 
many trees -- just cattle and grass. Frequently men can be seen on horseback, and often large herds of cattle are being driven along the highway. The land nearer Managua is not as level, and the farms are smaller and dedicated to row crops.

The quinta (country home) of the G. family is in great contrast to the small houses we had seen along the highway and in the villages. Their hospitality was gracious and complete.

(November 8, 1964, visits to EI Salto and Masatepe) Different crops are to be seen as the elevation and degree of levelness of the land change. Cotton and cattle are found on the low, level lands; coffee on the highlands; and small grains and fruits on the intermediate areas.

(November 10, 1964, visit to the coffee plantation, Armenia) The workers are just beginning to come in for the picking season. They come from many parts of Nicaragua and live in the sheds provided as barracks. Both men and women pick coffee, and some bring children with them also. The large drying floor and processing plant make up the main installations. There are no sanitary facilities.

Brief visits were made to the villages of Los Rizos, Los Gutierrez, San Pablo, and Los Sanchez. All except San Pablo are village-like clusters. San Pablo is near the cement factory, and many work there. The trip was made by jeep with considerable difficulty. Two stops were made to get permission to drive through large farms, as the public road could only be traveled by foot or horseback. Three rivers were forded in the trip, and at one point the jeep had to be counter-balanced on a hillside to keep from overturning. There are a number of small farms but much of the land was in large tracts. Some of the small operations are on a rental or share basis with the owner. Most of the people live in the villages. There are oxcarts to be seen in all of the villages, and some tractor equipment was observed on the large farms. The common tools to be seen everywhere were the machete and the macana (hoe-like tool).

(November 12, 1964, a trip to Los Rizos) All day was spent in this village and in another smaller village further up in the hills. During the slack work season, many of these people make charcoal. As a result of this enterprise few large trees are left. Great concern was expressed over a 
small stream and a spring that no longer furnished enough water for the community. The gradual drying up of the stream coincides with the clearing of the hillsides.

There is a new school in Los Rizos, constructed with help from Alliance for Progress funds. The people are proud of it, and it has the only toilet in the village. At a meeting with the farmers in the evening, we noted a high degree of interest in community improvement and increasing their agricultural production. Many requested help with their own agricultural problems.

(November 13, 1964, all-day visit in Los Gutierrez) One of the main enterprises in this village is a lime kiln owned by the Somoza family. Also, many people work on a Somoza farm that accounted for most of the land. The small river that runs beside the village is considered a real asset. Many women wash their clothes there. It also serves as the source of drinking water. Returning to the highway we passed a large dam that forms a reservoir for water and electrical power. This belongs to the cement factory.

(December 14, 1964, a visit to the dam at El Salto) This is one of three dams that were built in the 1930's as part of a plan to bring electricity to all of the Pacific zone. The dam has never been used, although it measures 17 meters wide and 15 meters high. The people of El Salto do not know why the dam has not been used. Another like it in Las Juntas is used for the cement factory. A third one in San Rafael (five kilometers distance) is also unused.

(December 17, 1964) I visited with don $R$. in his office at the Seguridad Social and got names of people in government agencies. Later I visited with two departments of Public Health, obtained written material, an offer of demonstration toilets, and saw the results of their health surveys in rural areas.

I talked with Ing. R., director of the Agricultural Extension Service, and got first-hand information on their program. He confessed that there were many problems and little backing for an extensive program. Fifteen copies of 20 different agricultural bulletins were given for distribution in the villages.

(A trip to Las Maderas in the evening) We passed again through the cotton area of Chilamatillo and into the beginning of rolling hills. This was a lumbering 
area 20 years earlier but now the second growth only serves for charcoal. Some farming is done on a small scale on the cut-over land but most of the villagers work as cotton laborers or deal in lumber from other areas.

(December 18, 1964, a visit with don J., national director of the credit unions) He spoke of the problems faced by the small producer and how they were helping establish marketing cooperatives in some of the coffee areas. Films were made available for the villages.

(An afternoon and evening visit to Masatepe) This is an old town in the rolling hills south of Managua. I talked with a grain dealer about the kind of fruits and grains produced in the area and also talked at length with don N., a successful businessman of the locality.

(November 19, 1964, a visit to the Ministry of Education) I talked with don A., chief of the division of Literacy and Community Development. He indicated that literacy is their key concern at the moment. He feels that adult illiteracy in the rural areas reaches 70 per cent. One of the great problems mentioned was that of the agricultural laborer and his lack of skills.

(An afternoon and evening trip with Mr. M. to Jicarito de León) Mr. M. is working in the establishment of rural electrical cooperatives. The problems of rural life were discussed at length. He contrasted the situation in Nicaragua with midwestern United States and saw many difficulties in establishing successful electrical cooperatives because of the differences.

(November 20, 1964, visits to the ministries of Public Health and Education) A plan for direct help to the villages was reconfirmed and the process for initiating this help was agreed on.

(A trip to Chinandega in the afternoon and evening) This is a cotton growing center. The town is of good size but I was impressed with the poor repair of the streets. Waste water runs into the unpaved streets, leaving a mixture of dust and mud.

(February 21, 1966, a trip by car from Alajuela, Costa Rica to Masaya, Nicaragua) Things look much the same as they did in years previous. There is some improvement in 
the highways and, except for a small stretch, they are all paved and in good repair. The large cattle ranches have changed very little.

(February 23, 1966, a trip to Managua and the airport) There appears to be an increase in economic activity, and more small factories can be observed between Managua and the airport. At the military checkpoint the traffic is no longer stopped for inspection. The highways leading into Managua are full of buses, trucks, micro-buses, and jeeps.

(February 26, 1966) Dr. A. from the government clinic in Tipitapa explained the services that are available in relation to public health. He also outlined the health problems of the rural villages.

\section{(A visit to Nindirí) The fame of this town goes} back to the precolonial times. The name signifies "town of the chief." There is a private museum of pre-Columbian artifacts located here. Most of the men work in the cotton harvest and are not in the village at this time of the year. The village is known for its indifference to change.

(A visit to San Luis) This is an area of small clusters of houses at a number of spots. There are three villages within 15 minutes walk. Don J. owns a mediumsized farm that is operated by the family and some hired help at times. The main cash crop is cotton. He has his own oxen and a few cattle as well. His well is used by the neighbors, and they come to him and doña J. for advice on many things. His house is of wood but it is painted and there are flowers in the yard. He is building an addition to the back of the house and has had a sanitary toilet for some time. He lights his house with a gasoline lantern. All of the family are literate and have helped others to learn to read.

(February 27, 1966, a visit to the Masaya market) The market was full of people as well as products. Besides the regular articles found in all markets, there are many typically Nicaraguan items made of straw or wood. (This is a famous tourist spot.) Masaya is very dusty at this time of the year; only half of the streets are paved and the wind is strong enough to keep the dust moving. 
(February 28, 1966) The Masaya market was completely destroyed by fire in the predawn hours. The women set up provisional stands in the central plaza by the church, and there was the usual sale of agricultural products.

(March 1, 1966, a revisit to Nindirí) I watched the installation of a water system by the government. This is the first time that water has been available other than from open wells or from streams. One of the trainees reported finding a baby in a dirt corral in one of the houses.

\section{(A visit to the village of Niciniohomo) Traveling} on a side road off from the highway and up into rolling hills, I saw many isolated farmsteads. These are small family operations that grow a variety of fruits and grains. They have their own oxen and a few simple implements. The Niciniohomo school is large and has 16 teachers.

(March 3, 1966, a visit to the local office of Public Health) The health problems of the Masaya area were discussed. The officials were particularly concerned with the low level of health habits of the rural people. Toilets were offered to the villages at less than cost.

(March 4, 1966, a visit to the local office of the Extension Service) The director and home agents discussed at length the problems of the rural areas and gave some examples of progress. Some of the problems expressed were: low levels of literacy, low levels of health, lack of agricultural credit, lack of land available to the small farmers of the area, continued use of outdated farming methods, large families, and lack of motivation for improvement. Both agents spoke with pride of the progress of one community, La Laguna. A trip to La Laguna was suggested.

(March 6, 1966, talk with the community president of Monimbó) He told of the customs of Monimbó as a village of the past and the resentment that some of the older people had for the school teacher. Some of the young people who had been to school no longer respected the authority of the elders. Monimbó offers a contrast to nearby Masaya. Almost all the houses are of thatch, and the streets are winding paths cut from the dirt. This is where the festivals for the dead are held each year, and the teacher considers such things as contributing to the backwardness of the village. In spite of this, the 
teacher has been in her school for 12 years and chose to live in the community instead of commuting, as so many rural teachers do. The president of the community admitted that the men were at a great disadvantage even as agricultural laborers because they did not know how to read and write.

(March 8, 1966, a trip to Santa Cruz, near San Luis) There are no permanent houses here and no village. The scattered houses are only temporary shelters because the land rental arrangements do not allow any permanent buildings. In the first school survey, it was found that only two people in this area could read and write. There were slightly over 2,000 people in all.

I talked at length with don E. about the cotton crop and how he became involved. He owns a large truck that is used on the farm when needed, but his son uses it most of the time for commercial hauling. He also has a new diesel tractor with complete equipment for cotton farming except for harvesting. He indicated that this was the third year he has invested in cotton and it has gone well with him. He borrowed 50,000 c6rdovas on his equipment to rent the land and pay the planting expenses. If things went well he hoped to rent more land and add another tractor. Most of the land in the area is worked on a rental basis according to him. He did not say who the owner was. Don E. had started as an agricultural laborer and dresses no different from the field hands that worked for him.

(March 2l, 1966, a visit to La Laguna village) The agricultural extension agents have worked closely with this community for a number of years. The people have always shown more response and are eager to learn. Upon leaving the highway I noticed a new electric power line being erected. Some of the young men are helping in the clearing of the trees and brush. This is one of the first communities to organize an electric cooperative and raise the necessary amount of money to start the project. The people of La Laguna do not live in a close viliage cluster but live on their small farms. Upon arrival in the center of the community I found the extension agents helping the public health workers in a school vaccination project. They were also in the process of installing a number of toilets. The community organization is also eager to start adult literacy classes and has already invested in books for 40 pupils. The extension agents are proud of the progress of this community. 
(March 24, 1966, visits to Niguiniohomo and Caterina) Both of these communities are much the same. There has been a greater response to community betterment here than in the cotton areas. As in La Laguna, most of the people live on their land and work very little as laborers on larger farms. The production level is close to subsistence and there is little chance for mechanization because of the hills and the length of the dry season.

(March 25, 1966, San Luis) Through the visits of the doctors and the use of the film strips by the seminar trainees, the people became interested in building toilets. The last of six cement platforms were delivered today and the people paid 20 córdovas each for them.

(June 13, 1968, a talk in Managua with Ing. B. who has had considerable experience with agrarian reform in Nicaragua) He feels there are many problems in using available data in the study of man and land in Nicaragua. The categories used in the different agricultural census are not the same. The most accurate material comes from the latest investigation of the Banco Central. None of the material is accurate enough for computer analysis. He also feels that any study of rural society in Nicaragua must employ a wholistic approach using all of the information available from the various academic disciplines.

From this conversation, I also gather the impression that agriculture in the Pacific region has changed completely with the commercialization of cotton production. All of the subsistence farmers are being pushed out and are migrating to the cities or to the North-Central region. Because of the value of land, a new emphasis on property rights is emerging.

(June 14, 1968, a trip to Matagalpa and Jinotega in the North-Central region) This is a complete change from the Pacific lowlands. The terrain is rugged, with steep mountains and intemittent valleys. Farms can be seen scattered across the countryside, some in coffee, some in small grains and some in pasture land. Corn has been planted for a month now and is presently being cultivated by hand and with oxen where the land is level enough. Beans and rice are just now being planted.

I am told that further in the mountains there are still tierras baldías (unoccupied national lands) that are being settled. This land can still be claimed in the 
following way (according to the extension agent): up to 100 manzanas can be selected; the municipio judge is called out to verify the land measurements; a document called a "título provisorio" is drawn up; after a hearing this land is registered and later a legal title is given. The cost is 25 to 50 córdovas. (I assume that this is per manzana.)

Land can also be purchased but can run as high as 4,000 córdovas per manzana. If the land has no title, then only the cultivation rights are sold and the maximum price is about 500 córdovas per manzana.

The land is prepared for planting in the following way where it is level enough to use oxen: first, roturar (to break up) using a native plow; second, cruzar (to cross) using the same plow but going across the original furrows; then, planar (to level) using a leveling log pulled crossways; and finally, surcar (to furrow) done with the plow and at the distance desired for planting the crop. Hillside land is planted by first burning and then using the espeque (planting stick).

Some farm laborers come into the area to help in the coffee harvest. It was felt that there was no great problem with laborers, as there was in the cotton areas. Here almost everyone has land of his own.

(June 15, 1968, visits to San Lucas, San Ramon, and Santa Cruz, all near Masaya) It was interesting to visit the farm of don J. and doña J. again after more than two and one-half years. The whole area has become even more dedicated to cotton production than before. A large plantation near their farm had three cotton pickers and a whole yard full of other new machines. Many small houses for the laborers have been constructed also. This company has 15,000 manzanas under cultivation. The rural electrification project has reached this area, and all of the houses have installations. The area looks more prosperous in many respects, but the problem of adult illiteracy persists. Most of the laborers are neither interested in learning nor do they make any effort to send their children to school. All of the toilets that were bought previously have been installed and are in use.

\section{Don J. has just planted 5 of his 18 manzanas to} corn. The rest he will plant to cotton in July. For the first time he hired his land plowed by tractor for 40 córdovas per manzana. He did the rest of the operations himself, but could have had it disced for 20 córdovas per 
manzana and planted by machine for an additional 20. He has oxen, a native plow, a hiller, and an oxcart of his own.

Don E. is still renting land, although he changed tracts when the price went up to 300 córdovas per manzana. He has often considered going to the North-Central or Atlantic regions to claim new land but is "too old to start something new." Because of the fluctuations in cotton prices, he has started planting corn. Last year he got yields as high as 50 quintales per manzana (approximately 50 bushels per acre) using fertilizer and complete mechanization. I saw his son, don $G$. (who has driven tractors for years) cultivating sesame with a horse hooked up to a one-row cultivator. This was considered quite a novelty by the neighbors.

(June 17, 1968, a discussion in Managua with officials of the National Agrarian Institute) Most of the morning was spent with Dr. T. and Mr. R. We discussed some of the basic problems of rural society in Nicaragua and what is proposed by the Agrarian Reform Law. Of particular interest were some of the legal problems that were encountered in the attempts to change the agrarian structure.

(June 18, 1968, a visit to the Agricultural Extension office in Masaya) I was interested in hearing about the Plan Masaya (a comprehensive development plan for the departamento of Masaya) from the agents. All of the government agencies are cooperating in this project and it is well underway. La Laguna is one of the communities chosen for a pilot study. The progress of this community has continued since my visit in 1966.

(A visit with the national office of malaria control) There is probably no other organization that has closer contact with the people in isolated rural areas than the field workers of SNEM. I talked with the field supervisor, who travels all over the republic. He was able to give me valuable information on settlement patterns and systems of agriculture in all parts of the country. He also gave me sketch maps of some of the small areas in each of the geographical regions. 


\section{BIOGRAPHICAL SKETCH}

Mr. Edgar G. Nesman was born in Lansing, Michigan on December 24, 1926. His undergraduate studies were pursued at Michigan State University, at East Lansing, Michigan, where he received the degree of Bachelor of Science in Agricultural Mechanics in 1950. Subsequently, graduate work was done at Scarritt College in Nashville, Tennessee, and later at Michigan State University, where he received the degree of Master of Science in Agricultural Extension (with a minor in Rural Sociology) in 1960.

Mr. Nesman served as a professor and consultant in rural work with the Methodist Church in Latin America from 1950 to 1966. He lived part of this time at the Agricultural and Industrial School in Oriente, Cuba, and later in Costa Rica. He has traveled in most of the other countries of Latin America, and has taught and conducted special surveys in Costa Rica, Nicaragua, Peru, Bolivia, Mexico, the Dominican Republic, Panama, and Chile.

He was honored with a graduate school fellowship at the University of Florida in 1966, is listed in Who's Who in Methodism, is a member of Alpha Kappa Delta, 
national honorary sociological fraternity, and a member of Alpha Zeta, national honorary agricultural fraternity. 
This dissertation was prepared under the direction of the chairman of the candidate's supervisory committee and has been approved by all members of that committee. It was submitted to the Dean of the College of Arts and Sciences and to the Graduate Council, and was approved as partial fulfillment of the requirements for the degree of Doctor of Philosophy

March 1969.

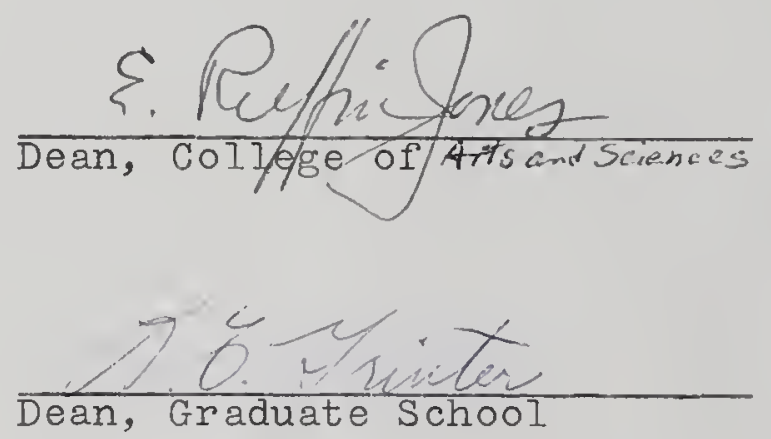

Supervisory Comittee:

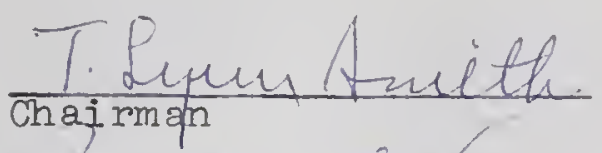

$-\infty=2 \pi x$
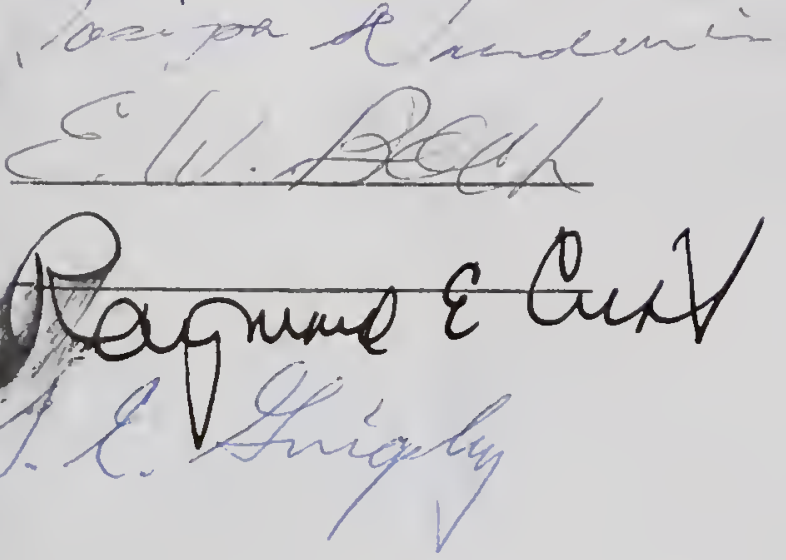